\title{
TRANSIENT OCCUPANCY
}

THE RESURGENCE OF PUBLICS IN

DOWNTOWN TORONTO

by

\section{Luke Rivet}

A thesis submitted to the Faculty of Graduate and Postdoctoral Affairs

in partial fulfillment of the requirements for the degree of

\section{Master of Architecture}

Carleton University

Ottawa, Ontario 


\section{ABSTRACT}

This thesis uses contemporary architectural theory to investigate a distinct set of concerns in the financial district of Toronto. In its investigation it uses two of Rem Koolhaas's ideas, that of Bigness as described in 1994 in “Bigness or the Problem of Large" and that of the Staging of Uncertainty a concept defined in Koolhaas’s 1994 article “What Ever Happened to Urbanism” and largely consistent with ideas developed in his book Delirious New York, 1978 to examines how Toronto's financial district is currently driven by capital.

To explore the issue of capital through the lens of Bigness and the Staging of Uncertainty the work uses a research-by-design methodology to develop a speculative design project that questions how this urban condition might be shifted to become more inclusive to concepts such as the Staging of Uncertainty instead of its singular focus on neoliberalism. 


\section{ACKNOWLEDGMENTS}

To my advisor, Johan Voordouw I would like to thank you for your dedication to this project. Without your guidance, advice and design sense, this project would not have been possible.

To my family, thank you for your undying support throughout my entire schooling. You guys are the reason I didn’t fully lose my mind.

To my friends (both at school and outside of it), the last six years feel like a fever dream but we've always had fun. Although not all of you are here at the moment, I know that wherever life has taken you you've always got my back. 


\section{TABLE OF CONTENTS}

\begin{tabular}{|c|c|c|}
\hline & ACKNOWLEDGMENTS & III \\
\hline & LIST OF IMAGES & V \\
\hline 01 & KEY TERMS & 2 \\
\hline 02 & LITERATURE REVIEW / THEORETICAL FRAMEWORK & 6 \\
\hline 03 & INTRODUCTION & 10 \\
\hline 04 & SITE & 13 \\
\hline 05 & DESIGN PROCESS & 25 \\
\hline 06 & PROGRAM & 34 \\
\hline 07 & REALIZATION & 42 \\
\hline 08 & CONCLUSION & 79 \\
\hline & BIBLIOGRAPHY & 81 \\
\hline
\end{tabular}




\section{LIST OF IMAGES}

\begin{tabular}{|c|c|c|}
\hline Img 01 & Initial Sketch & 1 \\
\hline Img 02 & Bigness / Uncertainty & 3 \\
\hline Img 03 & Site Analysis & 12 \\
\hline Img 04 & Site Photo & 13 \\
\hline Img 05 & Site Photo & 14 \\
\hline Img 06 & Site Photo & 15 \\
\hline Img 07 & Site Photo & 15 \\
\hline Img 08 & Site Photo & 16 \\
\hline Img 09 & Brookfield & 19 \\
\hline Img 10 & Sun Life & 20 \\
\hline Img 11 & ОТРР & 21 \\
\hline Img 12 & Omers & 22 \\
\hline Img 13 & BCIMC & 23 \\
\hline Img 14 & Temporal Connections & 26 \\
\hline Img 15 & Tensile Connection & 27 \\
\hline $\operatorname{Img} 16$ & Iterative Sketches & 28 \\
\hline Img 17 & Vertical Inhabitation & 29 \\
\hline Img 18 & Hanging Structures & 30 \\
\hline $\operatorname{Img} 19$ & Drink Cola & 32 \\
\hline Img 20 & Daytime Population & 36 \\
\hline Img 21 & Population Age & 36 \\
\hline Img 22 & Income & 37 \\
\hline Img 23 & Labour Types & 37 \\
\hline $\operatorname{lmg} 24$ & Education & 38 \\
\hline Img 25 & Children & 38 \\
\hline $\operatorname{lmg} 26$ & Commute Data & 39 \\
\hline Img 27 & Masterplan & 43 \\
\hline Img 28 & Skyscraper Occupation & 45 \\
\hline Img 29 & Tensile Model & 48 \\
\hline Img 30 & Tensile Model & 49 \\
\hline Img 31 & Tensile Model & 49 \\
\hline
\end{tabular}




\begin{tabular}{|c|c|c|}
\hline Img 32 & Duration Diagram & 51 \\
\hline Img 33 & Housing Community & 53 \\
\hline Img 34 & Financing Model & 56 \\
\hline Img 35 & Building Section & 58 \\
\hline $\operatorname{lmg} 36$ & Private Program & 59 \\
\hline Img 37 & Community & 60 \\
\hline Img 38 & Floor - 2 & 61 \\
\hline Img 39 & Floor 2 & 62 \\
\hline Img 40 & Floor 7 & 63 \\
\hline Img 41 & Floor 44 & 64 \\
\hline Img 42 & Floor 63 & 65 \\
\hline Img 43 & Floor 64 & 66 \\
\hline $\operatorname{lmg} 44$ & Floor 73 (Roof) & 67 \\
\hline $\operatorname{lmg} 45$ & Conceptual Diagram & 68 \\
\hline Img 46 & Public Program Voids & 69 \\
\hline Img 47 & Program Classification & 70 \\
\hline $\operatorname{lmg} 48$ & Program Codification & 71 \\
\hline Img 49 & Program Codification & 72 \\
\hline Img 50 & Tower Model & 73 \\
\hline Img 51 & Tower Model & 74 \\
\hline Img 52 & Tower Model & 75 \\
\hline Img 53 & Tower Model & 76 \\
\hline Img 54 & Tower Model & 76 \\
\hline Img 55 & Tower Model & 76 \\
\hline $\operatorname{lmg} 56$ & Building Exterior & 77 \\
\hline Img 57 & Armature Connection & 78 \\
\hline
\end{tabular}




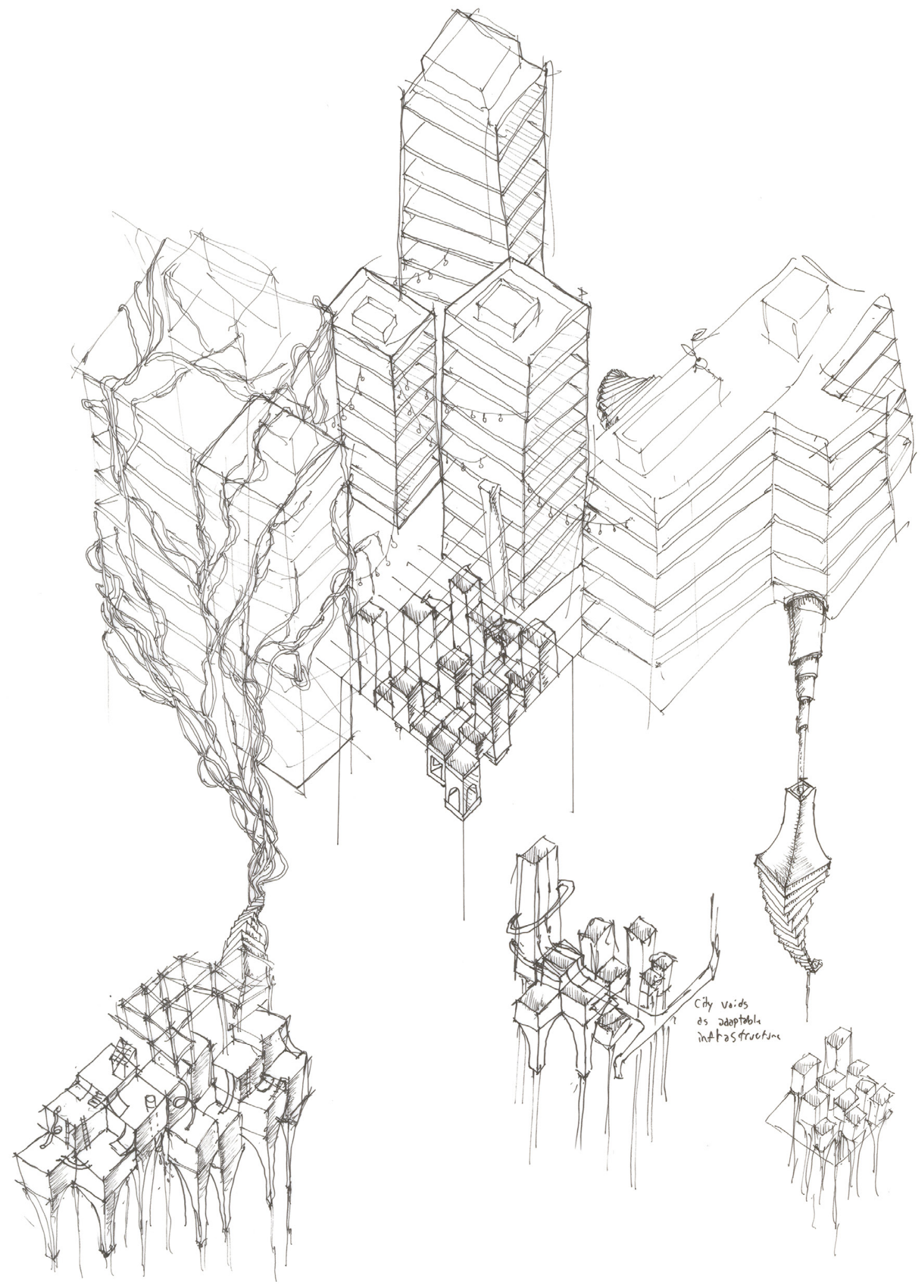

Img 01 | Initial Sketch

Considering the city as a system of infrastructure that adapts

to the changing needs of society. This sketch was drawn at the 


\section{1}

\section{KEY TERMS}

1 Koolhaas, Rem, and Bruce Mau. S, M, L, XL. Monacelli Press, 1993. pp. 511

2 Koolhaas, Rem. Delirious New York. Monacelli Press, 1978. pp. 85

3 Koolhaas, Rem, and Bruce Mau S, M, L, XL. Monacelli Press, 1993. pp. $961-971$

\section{Bigness}

Bigness was coined by Rem Koolhaas to embody the essence of the extremely large building and their inability to be controlled by a single architectural gesture once they reached a critical mass. The big building becomes acontextual, it becomes the urban tissue that it replaces. "A paradox of Bigness is that in spite of the calculation that goes into its planning - in fact, through its very rigidities - it is the one architecture that engineers the unpredictable." '

It is this unpredictability that allows this thesis to consider Bigness and the Staging of Uncertainty together as two theoretical inspirations for the design project. These two concepts are not in opposition, but different extensions of the same observation of the large, financedriven urban center.

\section{Staging of Uncertainty}

The exact term was first used by Koolhaas in his 1994 essay, What Ever Happened to Urbanism yet its roots call back to his analysis of the skyscraper (or more specifically the Downtown Athletic Club) in Delirious New York. The analysis of the skyscraper views each separate floor as no longer beholden to a single predetermined purpose. ${ }^{2}$ The Staging of Uncertainty is characterized by its lack of permanence and solidity as it exists within its existing urban condition, this ephemerality allows this new architecture to adapt to the shifting needs of society. ${ }^{3}$ 


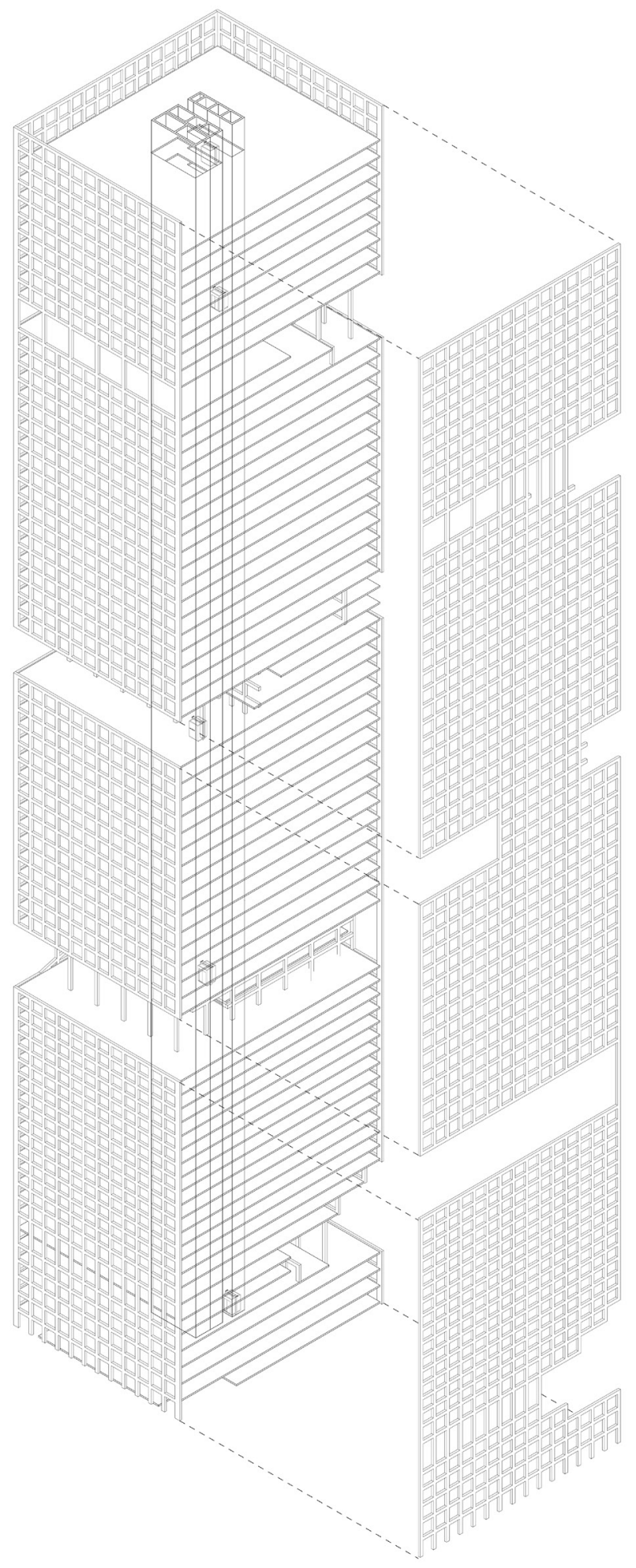

Img 02 | Bigness / Uncertainty

Left : Bigness exemplified in the large empty floorplates disconnected from the

facade and the rest of the urban tissue
Right : Uncertainty as it integrates spaces for fluctuating program within the
framework of Bigness

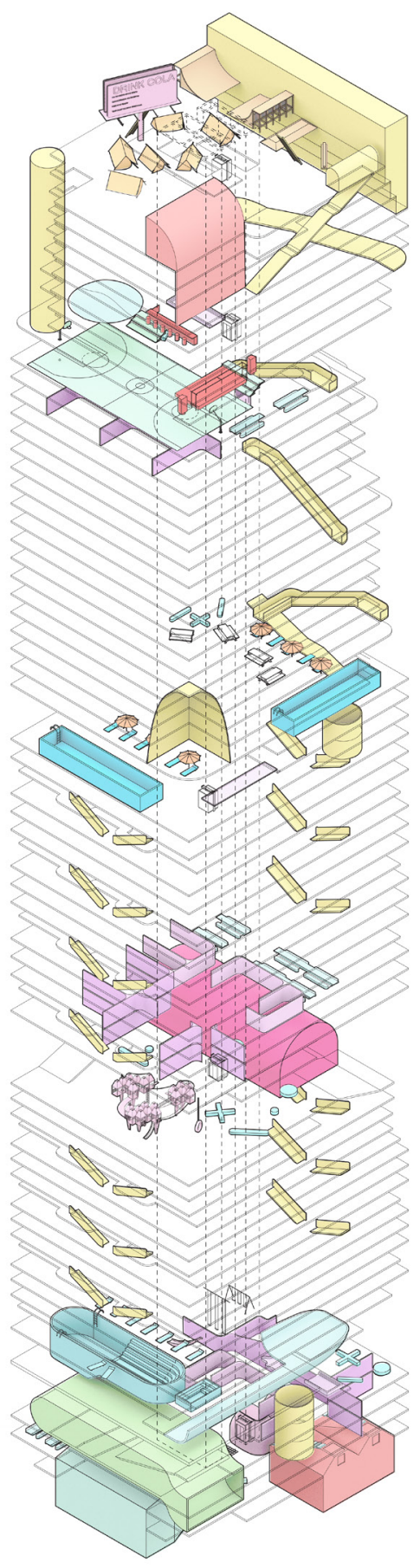


The uncertainty is examined in the multiple design stages of the thesis, the varying societal necessities create new impermanent programs. Toronto's financial district provides the context for new transient methods of occupation.

\section{Neoliberalism}

Neoliberalism is a political alignment that supports unrestricted free trade and open markets. This free market capitalism focuses on the minimal interference from governing agencies, and the reduction of taxation and regulation. The move towards the privatization of industry is largely supported by conservative individuals and corporations. ${ }^{4}$

The existing state of the financial district of Toronto is founded in its neoliberal structure, the Bigness of the district is a result of this. The thesis will examine how inhabitation and uncertainty is possible in a district dominated by this system. While this thesis addresses the neoliberal aspects of the financial district's environment, it focuses on the publics' inhabitation within this system and less on the economics of the spaces themselves.

\section{Control}

A confining system that removes non-conformity to strictly adhere to a set of predefined parameters. The site will be analyzed as a system of control. Control will focus on how spaces in a city are dictated by companies through the design of their built architecture. Direct control is exercised on the site through the manufactured hostility of built architecture and privately-owned spaces.

The thesis studies power as it relates to the corporations that control the site. Control is not used to directly dictate the movements and lives of the population that inhabits the region, it is used to create a neighbourhood that is homogenized in its inhabitants, spaces and operations. 


\section{Publics}

When describing publics, it is important to note the difference as indicated by Michael Warner in Public and Counterpublics between The Public and $A$ Public. As a general description, the public is a much broader term that encompasses a grouping of people in general. This general grouping of people encompasses willing or unwilling populations within a certain area, demographic or country. The definition is different from A public which cannot be identified through an external framework, such as government identification or demographic polls. A public is self-organized and exists through occupant participation or self-identification. A public becomes a grouping of people that share common interests and positions. This definition of public leads to the conclusion that there is not a singular public in which everything can be tailored to and addressed. A body of people is composed of a multitude of different overlapping publics that contains different goals, participants and social classes. ${ }^{5}$

The thesis studies how the architecture of Bigness in Toronto can be transformed to adapt to the various publics that do not currently inhabit the site. The multiplicity and ambiguity of the various publics require spaces that can adapt to their overlapping and changing desires. The design of the thesis addresses the nebulous needs of the publics with designs that adapt. 


\section{LITERATURE REVIEW \\ 02 / THEORETICAL FRAMEWORK}

6 Scott, Felicity. Architecture or Techno-Utopia: Politics after Modernism. MIT Press, 2007.

7 Koolhaas, Rem. Delirious New York. Monacelli Press, 1978. pp. 100

8 Ibid.pp. 85

\section{Delirious New York. 1978. Rem Koolhaas.}

A central theme of the thesis revolves around Rem Koolhaas' notion of The Staging of Uncertainty. He explores ideas of architecture as a framework for unknowable urbanism through his retroactive reading of New York. The term Manhattanism is coined for the urban condition created by the density of skyscrapers dictated by its lack of ideologies and doctrines. This condition is seen as a product of capitalist development and not intentional urbanism. ${ }^{6}$ This new form of architecture does not follow a movement or manifesto; it is simply a result of the city. It is in this text, Rem Koolhaas lays the groundwork for his essay on Bigness found in S,M,L,XL (1995). The term Bigness does not appear in Delirious New York, but he identifies the city's urbanism as buildings that have gone beyond a critical mass and have becomes monuments. The New York skyscraper represents a separation between the interior programmatic occurrences and the exterior expressions of the buildings. ${ }^{7}$ Floorplates have increased in size to the point where the vertical circulation of the building has no effect on the buildings' articulation. It is this split that enables each building lot to accommodate “an unforeseeable and unstable combination of simultaneous activities, which make architecture less an act of foresight than before and planning an act of only limited prediction." ${ }^{8}$ Koolhaas reads Manhattan’s urban fabric as a grid of monoliths that house unstable and unpredictable program. 
Manhattanism is embodied in the Downtown Athletic Club through its vertical stacking of program, completely disconnected from the surrounding urban environment. The new technology of the elevator enabled buildings such as the Downtown Athletic Club to divide its organization vertically. The vertical circulation renders the existing streetscape obsolete.

9 Koolhaas, Rem, and Bruce Mau. S, M, L, XL. Monacelli Press, 1995. pp. 499

10 lbid. pp. 506-507

11 Yoos, Jennifer, et al. Parallel Cities: The Multilevel Metropolis. Walker Art Center, 2016. pp. 30

12 Koolhaas, Rem, and Bruce Mau. S, M, L, XL. Monacelli Press, 1995. pp. 512

\section{Bigness or the problem of Large. S,M,L,XL. 1994. Rem Koolhaas.}

The direct lineage from Delirious New York to Bigness is apparent in Koolhaas' own words, he describes Bigness as a condition without thinkers, Delirious New York implies a " latent 'Theory of Bigness' "9 The impossibly large mass of the structure creates independent parts and programs that collectively create the Big Building. This new architecture negates the urban fabric and becomes its own context. Koolhaas argues that the new urban typology created by Bigness enables programmatic "hybridizations/proximities/frictions/overlaps/superpositions". ${ }^{10}$ The overlapping of program and social spaces is reminiscent of the utopian visions of the Social Condenser theorized by the Russian Constructivists. They focused on programmatic superposition with the intent to achieve "social cohesion through appropriate forms of architecture and urban design"." The Constructivists were deeply critical in their approach to architecture as a tool for social change. In Bigness, Koolhaas is identifying its programmatic capabilities and exploring the skyscraper as a method to organize relationships within the existing capitalist system. Despite its potential for programmatic instability, Koolhaas declares that Bigness is also a blueprint for blandness. ${ }^{12}$ This blandness is due to the unmitigated vastness of the Big Building, it yields to the whim of the market forces that drive its program. It is at this moment when the fantastical reading of the Downtown Athletic Club in Delirious New York is faced with opposition. 
13 Koolhaas, Rem, and Bruce Mau.

S, M, L, XL. Monacelli Press, 1995.

pp. 961

14 Ibid. pp. 969

15 lbid. pp. 971

\section{What Ever Happened to Urbanism. S,M,L,XL. 1994. Rem Koolhaas.}

Rem Koolhaas' polemical essay What Ever Happened to Urbanism expresses his views on the failures of Modernism's “Alchemistic promises - to transform quantity into quality through abstraction and repetition”. ${ }^{3}$ He identifies and criticizes Modernism's tabula rasa approach to urbanism and their attempts to create a new beginning through the design of urban plans. Koolhaas removes urbanism from the equation of city design and replaces it with chaos and architecture. He views cities as an amalgamation of transitory objects without definition. "If there is to be a 'new urbanism' it will not be based on the twin fantasies of order and omnipotence; it will be the staging of uncertainty; it will no longer be concerned with the arrangement of more or less permanent objects but with the irrigation of territories with potential;" ${ }^{14}$ Urbanism in this new setting is not the design of definitive forms, but the staging of impermanent occupation of space. This chaos cannot be deliberately manufactured to fit specific goals, instead it is given the potential to develop in urbanizing cities. This essay aims to redefine the role of designer and their relationship with the city. ${ }^{15}$ The relationship shifts from that of a designer to that of a participant that is subjected to the current of the whims on the city and shifting needs of the population and markets. This relationship is in accordance with Koolhaas' own approach to criticality in work with the Office for Metropolitan Architecture (OMA) and its associated research office (AMO). It comments on the state of architecture as it relates to society, without proposing radical change; it is an observer, not an active agent. The proposed urbanism does not deny the pre-existing, it layers, modifies and superimposes. The new relationships/hybridizations of the new and old will create the new urban condition. 


\section{Synthesis}

This thesis evaluates the current applications of the concept of Bigness as it exists in Toronto's urban center and explores how this architecture can become the framework for the Staging of Uncertainty. Bigness as it exists within the chosen site takes the shape of the high-rise office tower. Increasingly, the towers become taller and the floorplates become larger, separating the use of the building from the exterior expression and larger urban context. This schism, emblematic of Koolhaas' theory of Bigness, is said to enable programmatic instability, yet in this context, it consolidates the business-oriented design. This project analyses how Bigness is used in the financial district and how the influence of commercially driven powers create the exclusionary design of the region. The large building, instead of being used as a tool for intensity, is used for homogeneity. The study of the urban condition is done in two ways: 1. In the analysis of the companies that own and lease the space (both at street level and in the air) 2. Through the identification of the subordinated publics that are excluded from the district. The thesis will explore how the existing context of Bigness can enable the programmatic hybridizations and superpositions that are visible in Koolhaas' writing of What Ever Happened to Urbanism and his reading of the Downtown Athletic Club and in Delirious New York. 


\section{3}

\section{INTRODUCTION}

16 Koolhaas, Rem, and Bruce Mau.

S, M, L, XL. Monacelli Press, 1993. pp. 495-516
Bigness exists in its lack of context, ${ }^{16}$ Toronto's financial district is comprised of a grid of isolated monoliths that adhere to its the principles of Bigness. The system of skyscrapers is splintered into vertical parcels completely distinct from each other, vertical circulation in this district is limited, this creates a disconnect between the ground plane and the privatized space in the sky. The design of the neighbourhood is dictated by the consumer and capital driven goals of private corporations. The companies' primary objectives are that of generating income for the owners and stockholders. These goals have no overlap with the interests of the alternate publics. This lack of alignment between the dominant publics of the corporation and the non-dominant publics creates spaces that are suited for the office-worker, not community activity.

The proposed design of the thesis questions the nature of power and its influence on design. The design task was chosen due to the site's existing potential for programmatic overlaps, hybridizations and community space. The existing infrastructure and large amount of people inhabiting the site provides a rich context that currently is not being utilized to benefit a broader group of people. The research analyses the constituent parts of the site and proposes a new framework that encourages occupation inside the constraints of the existing neoliberal structures. 
A time-based system of design developed in three stages will occupy the financial district and subsequently the surrounding areas, creating a network of staged uncertainty.

The nature of space and its relation to people requires different publics to be addressed. The dominant publics that subordinated classes traditionally oppose are the owners and participants of the capitalist companies that control the site. This public represents those working in the most common industries of finance, real estate and professional services. The nondominant (or alternative) public exists in relative opposition to the powers that oversees the district. The different publics described in this thesis are comprised of varying groups of people that hold different values, goals and belong to vastly different social classes. The alternative publics are the multiple groups of perceived lower status individuals that do not directly participate in this consumerist system. The alternative publics are subject to the public sphere that is dominated by the dominant publics. ${ }^{17}$ It is important to note that individuals often belong to many publics, one person's entire identity and needs cannot be reduced to their profession. As a result of this, one person might belong to several different publics throughout the course of a day. The new architectural language will be brought to life in a system that denies the non-dominant public's relationship to the space. A negotiation of the divide between public and private must occur to create a theory that speculates the future of multiple publics' occupation of the district. 


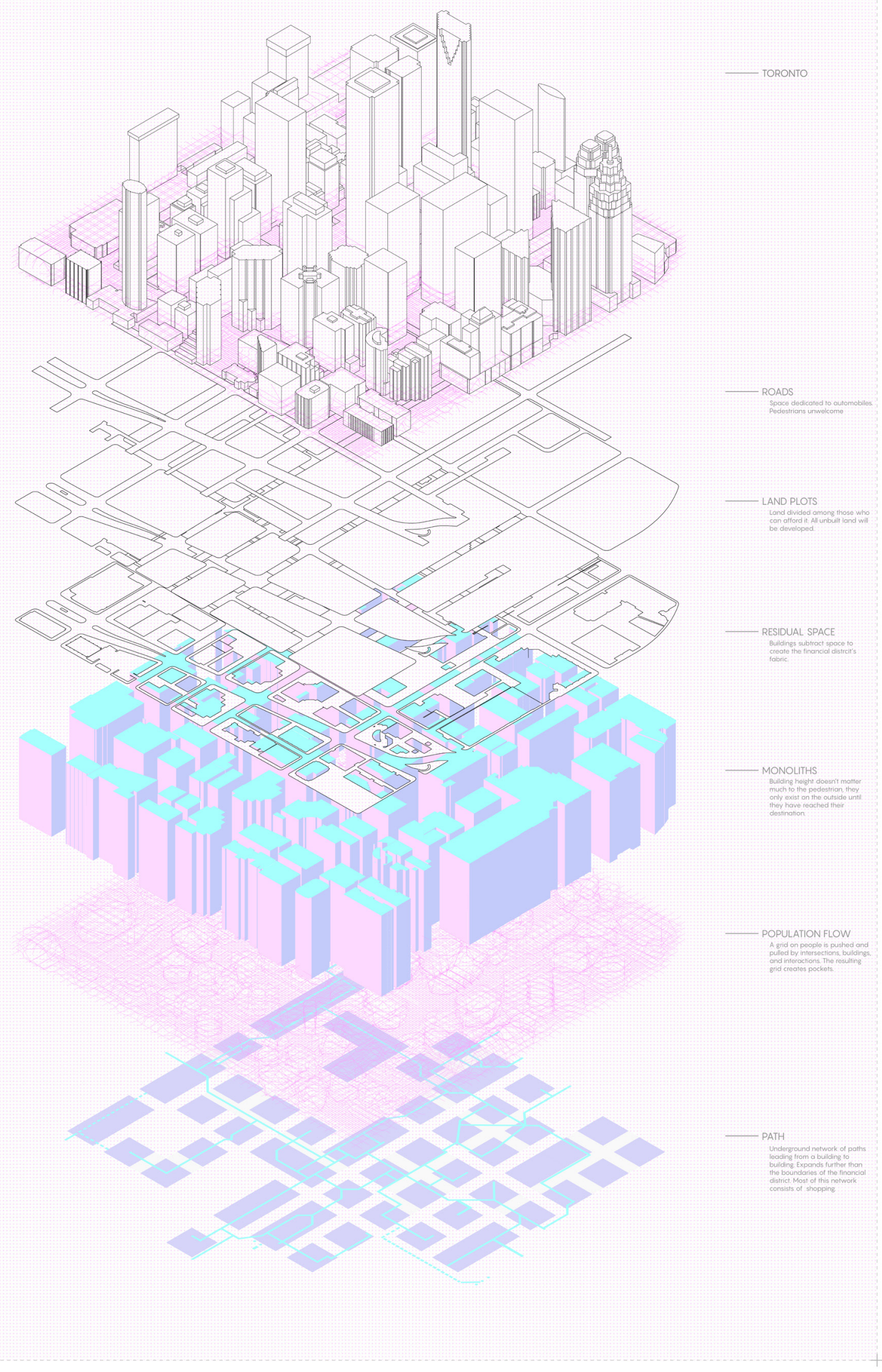

Img 03 | Site Analysis

Considering the site and how people move through it. The analysis

looks at how the large footprints of the buildings affects human 
04

\section{SITE}

The project's site is located in the financial district of Toronto. The district is bordered by Yonge St. and Simcoe St. on the East/West borders and between Queen St. W and Front St. W on the North/South. The site occupies $17 \mathrm{~km} / \mathrm{sq}$. and houses approximately 30 high-rise buildings and approximately 15 low to mid-rise buildings. The site was selected for its density and verticality. Due to its central location, real estate is at a premium, this premium promotes the skyscraper as the only building option when purchasing land in the district.

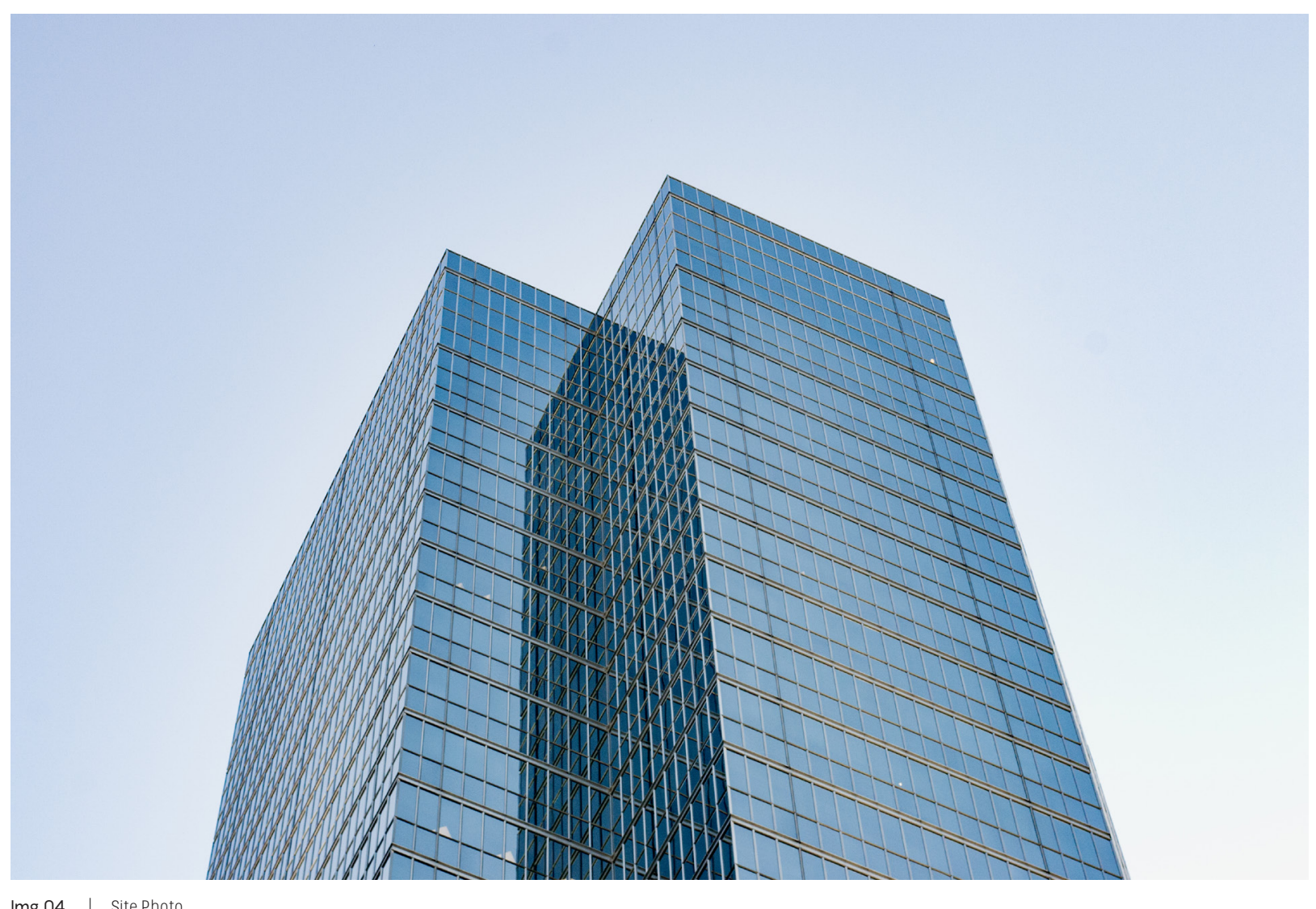




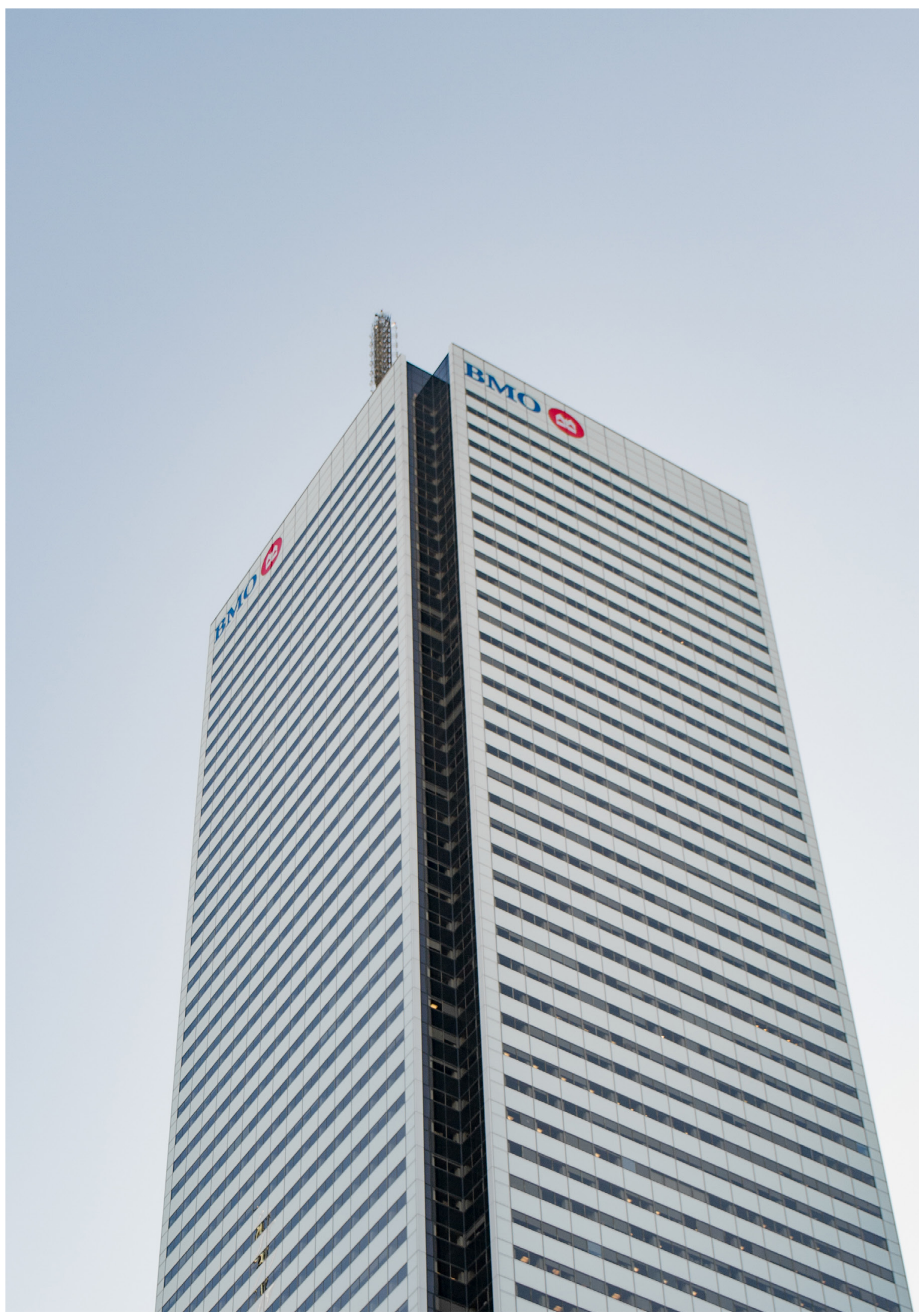




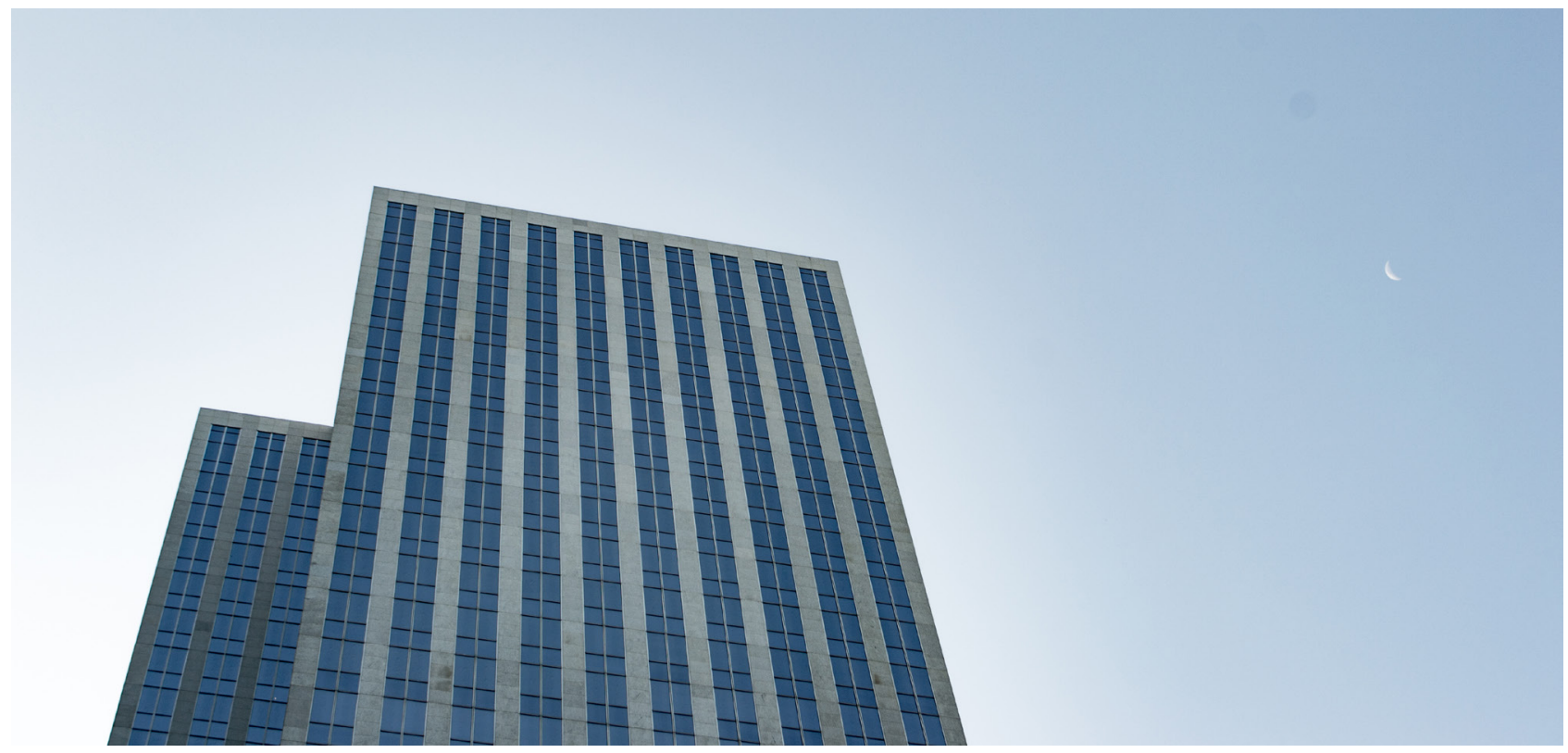

Img 06 | Site Photo

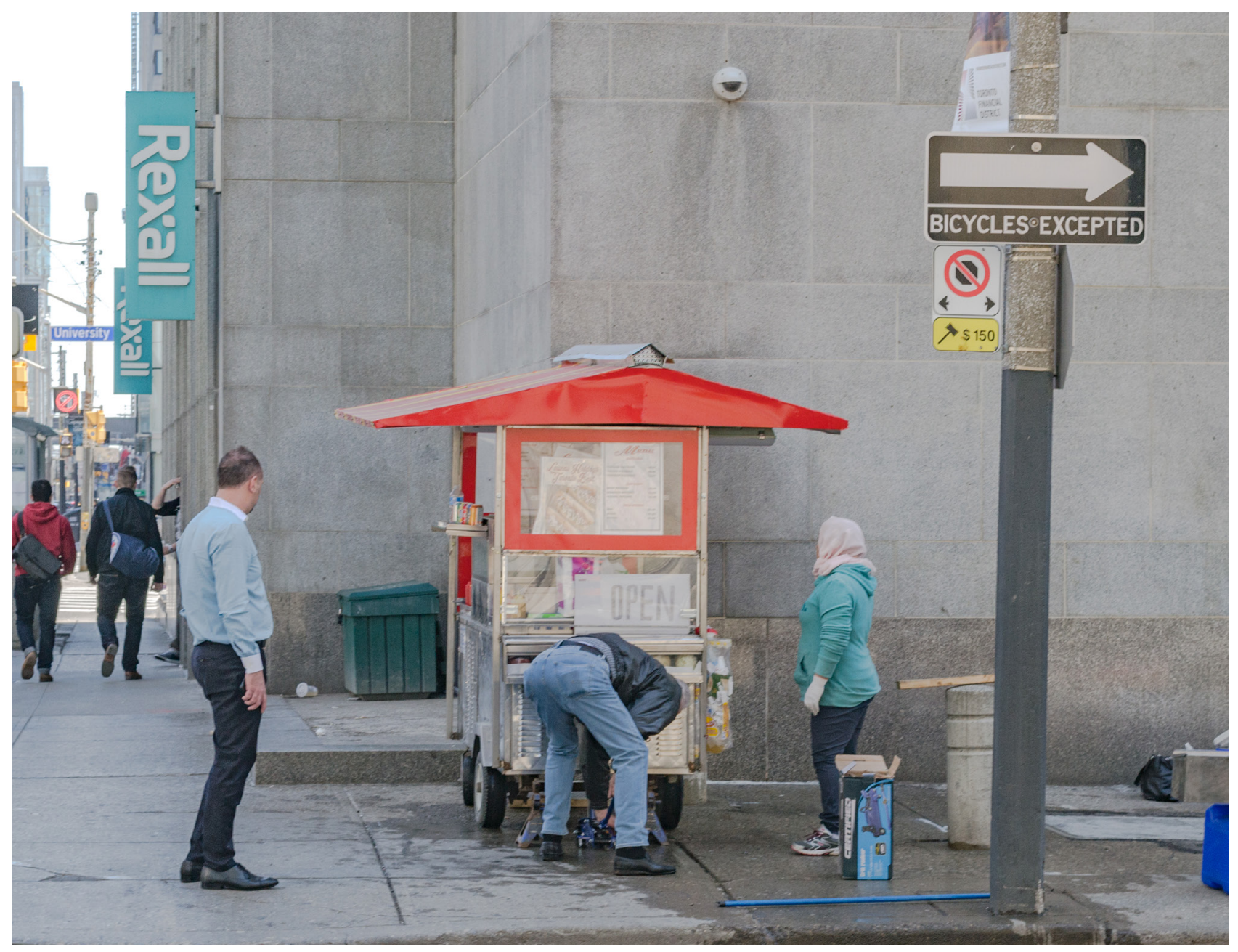

Img 07 | Site Photo 
Downtown Toronto serves as a working destination for the Greater Toronto Area. This area is home to almost 6 million inhabitants. A great number of suburbs have direct train or express busses to the center. Toronto's amenities and transportation systems are predominantly focused on the financial market. Many commuter and inter-city trains arrive at Union Station. The Line 1 subway, the Queen streetcar and King streetcar run directly through the site. Accessing this neighbourhood 24 hours a day can be achieved easily. The neighbourhood sees most of its activity between 9am and 6pm Monday to Friday.

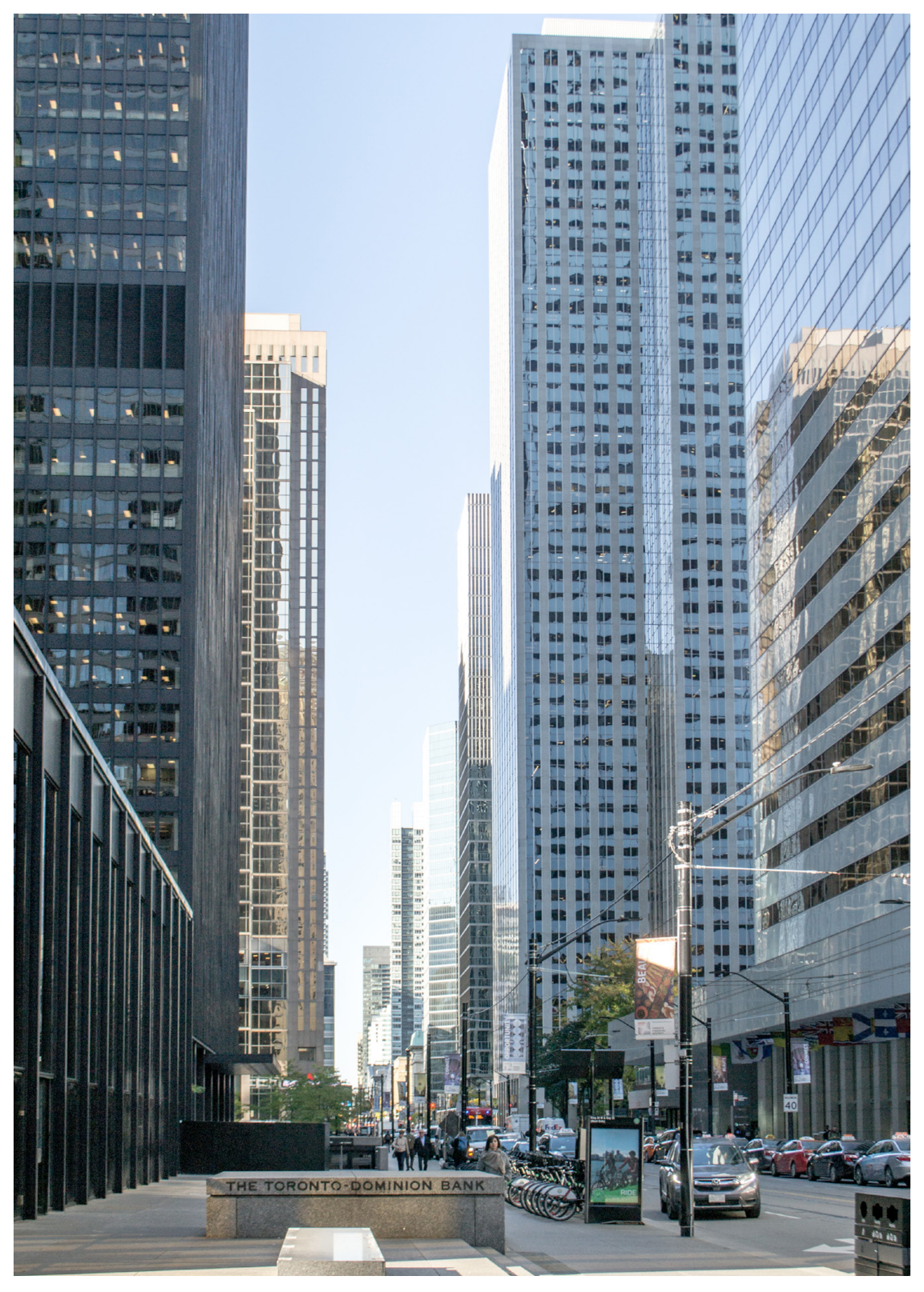


18 Brookfield Property Partners L.P. 2018 Annual Report. 2018. Web. 10 November 2019 https://bpy.brookfield $\mathrm{com} /$ reports-and-filings/

financial-reports/annual-reports

19 Sun Life Financial Inc. 2018 Annual Report. 2018. Web. 12 November 2019 https://www.sunlife. com/Global/Investors/Presentations+and+events/Annual+meetings?vgnLocale=en_CA

20 Sun Life Financial Inc. Management Information Circular. 2019. Web. 12 November 2019 https:// www.sunlife.com/Global/Investors/Presentations+and+events/ Annual+meetings?vgnLocale=en_CA
Proprietorship of the buildings that occupy the financial district can be narrowed down to five companies and their subsidiaries. The companies that hold majority stakes either run the buildings and tenants themselves or have a subsidiary branch owned by the corporation that runs the day to day operations and leasing of the space. Out of the 30 high-rise buildings in the district, 25 are owned by either: Brookfield Property Partners L.P., Bentall Greenoak Real Estate, Cadillac Fairview, Oxford Properties or Quadreal Property Group. The 5 high-rises that are not owned by these companies and their subsidiaries are hotels or residential buildings, every large office or commercial tower is owned by the corporations listed. The result of this proprietorship is a district that has homogenized its spaces, operations, corporate/leasing policies and general relation to the market, this homogenization is counter to Bigness' potential for causing uncertainty.

Brookfield Office Properties (subsidiary of Brookfield Asset Management) is a publicly traded company of the Toronto and New York stock exchange. Their net income for 2018 was $\$ 3.654$ billion USD and the total value of their assets is $\$ 122.520$ billion USD. This corporation holds $\$ 80.196$ billion USD in investment properties across multiple countries. ${ }^{18}$

Bentall Greenoak Real Estate (subsidiary of Sun Life Financial) is a publicly traded company on the Toronto and New York stock exchange. Their net income for 2018 was $\$ 2.947$ billion USD and the total value of their assets is \$951.142 billion USD. This corporation holds $\$ 2.809$ billion USD in investment properties across multiple countries. ${ }^{19}$ The salary of the chief executive officer of Sun Life Financial is $\$ 9.3$ million USD per year. ${ }^{20}$ 
21 Ontario Teachers' Pension Plan 2018 Annual Report. 2018. Web. 10 Nov 2019 https://www otpp.com/ corporate/ontario-teachers-reporting

22 Ontario Municipal Employees Retirement System. 2018 Annual Report. 2018. Web. 13 Nov 2019

https://www.omers.com/AboutOMERS/Annual-Reporting

23 British Columbia Investment Management Corporation. Cor-

porate Annual Report. 2018. Web.

13 Nov 2019 https://www.bci.ca/ publications/
Cadillac Fairview (subsidiary of Ontario Teacher's Pension Plan) is a privately held company. Their net income for 2018 was $\$ 5.2$ billion CAD and the total value of their assets is $\$ 191.1$ billion CAD. This corporation holds $\$ 27.5$ billion CAD in investment properties. The salary of the chief executive officer of the Ontario Teacher’s Pension Plan is $\$ 4.892$ million CAD per year. ${ }^{21}$

Oxford Properties (subsidiary of Ontario Municipal Employees Retirement System) is a privately held company. Their net income for 2018 was $\$ 9.266$ billion CAD and the total value of their assets is $\$ 111,862$ billion CAD. This corporation holds $\$ 22.256$ billion CAD in investment properties. The salary of the chief executive officer of the Ontario Municipal Employees Retirement System is $\$ 4.126$ million CAD per year. ${ }^{22}$

Quadreal Property Group (subsidiary of British Columbia Management Corporation) is a privately held company. Their net income for 2018 was $\$ 4.555$ million CAD and the total value of their assets is $\$ 129,4$ billion CAD. This corporation holds $\$ 3.1$ billion CAD in investment properties. The salary of the chief executive officer of the British Columbia Management Corporation is $\$ 3.315$ million CAD per year. ${ }^{23}$ 


\section{BROOKFIELD PROPERTY PARTNERS L.P}

\section{BROOKFIELD OFFICE PROPERTIES}

PUBLIC COMPANY TORONTO STOCK EXCHANGE

STOCK PRICE

BYP.UN

BOARD OF DIRECTORS

Ric Clark
Cocimen of the sox

Jefferey Bilidno

Soon Young Chang

Omar da Cunha

Stephen DeNardo

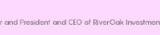

Lou Maroun

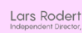

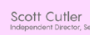

Caroline Alkinson
CAD $\$ 25.13$

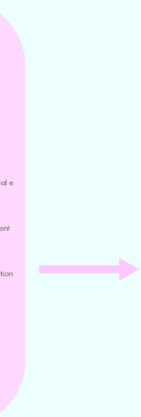

\section{ANCHOR TENANTS}

Bank of Montreal

Bank

Revenue $\$ 21,700,000,000$

Osler, Hoskin \& Harcourt LLP

Business Law Firm

Bennett Jones LLP

Law Firm

Deloitte

Accounting

Revenue $\$ 46,200,000,000$
2019

Toronto Stock Exchange

Stock Exchange

Revenue $\$ 817,100,000$
FINANCIAL (USD)

$\begin{array}{ll}\text { Net Income } & \$ 3,654,000,000 \\ \text { Total Revenue } & \$ 7,239,000,000 \\ \text { Investment Properties } & \$ 80,196,000,000 \\ \text { Total Assets } & \$ 122,520,000,000\end{array}$
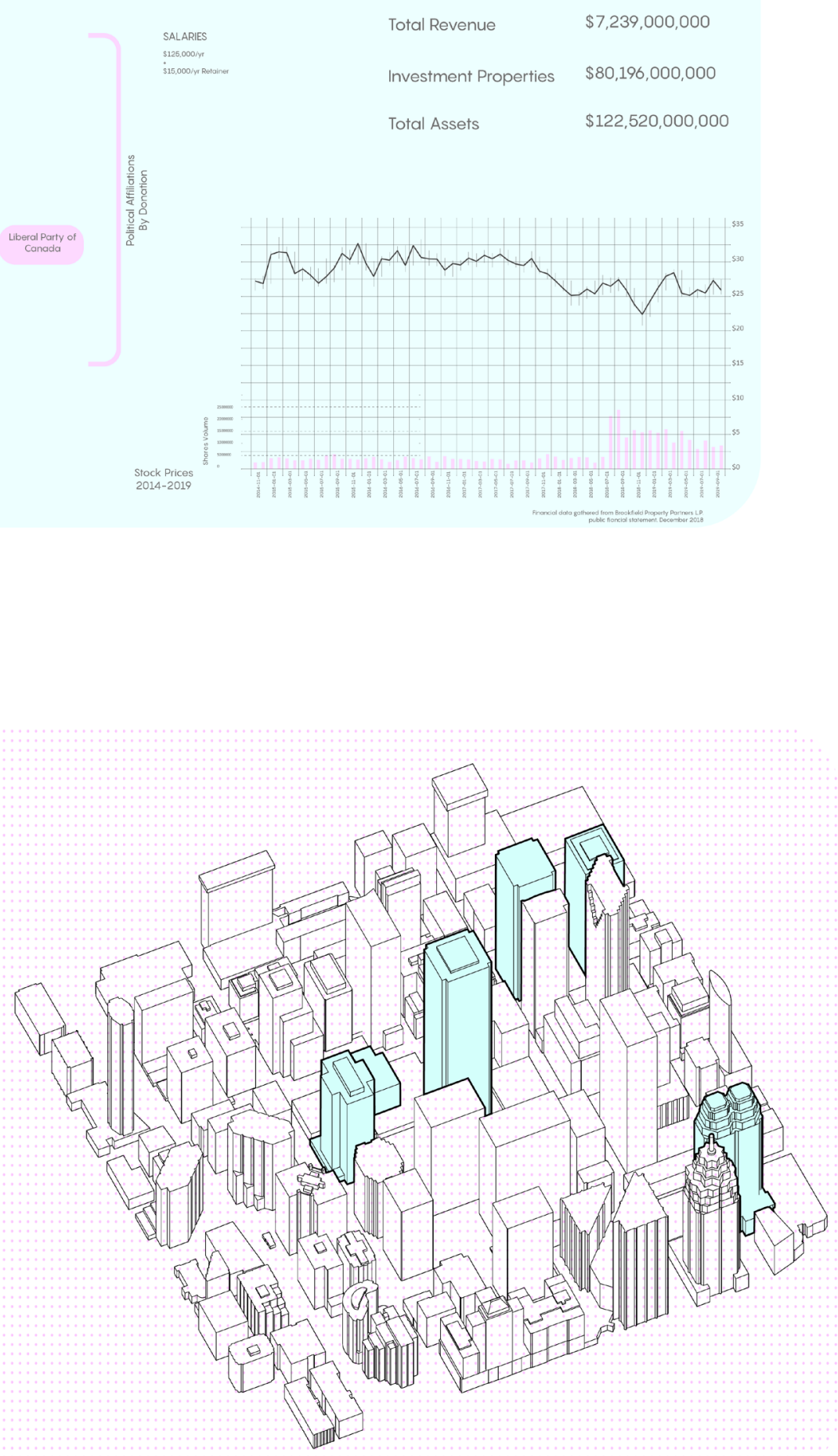


\section{SUN LIFE FINANCIAL}

\section{BENTALL GREENOAK REAL ESTATE}

PUBLIC COMPANY

TORONTO STOCK EXCHANG

STOCK PRICE

BOARD OF DIRECTORS

Williom D. Anderson

Ashok K. Gupta

Jomes M. Peck

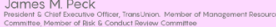

Dean A Connor

MMarianne Harris

Scott E Powers

Stephanie L Coyles

Sara Grootwassink Lewis

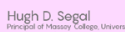

Martin J. G Glynn

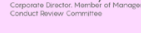

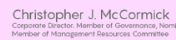

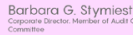

\section{SLF}

$\$ 58.88$

$=$

(1)

-

.

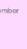

Liberal Party of
Conoda

Liberal Party of
Conoda

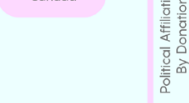
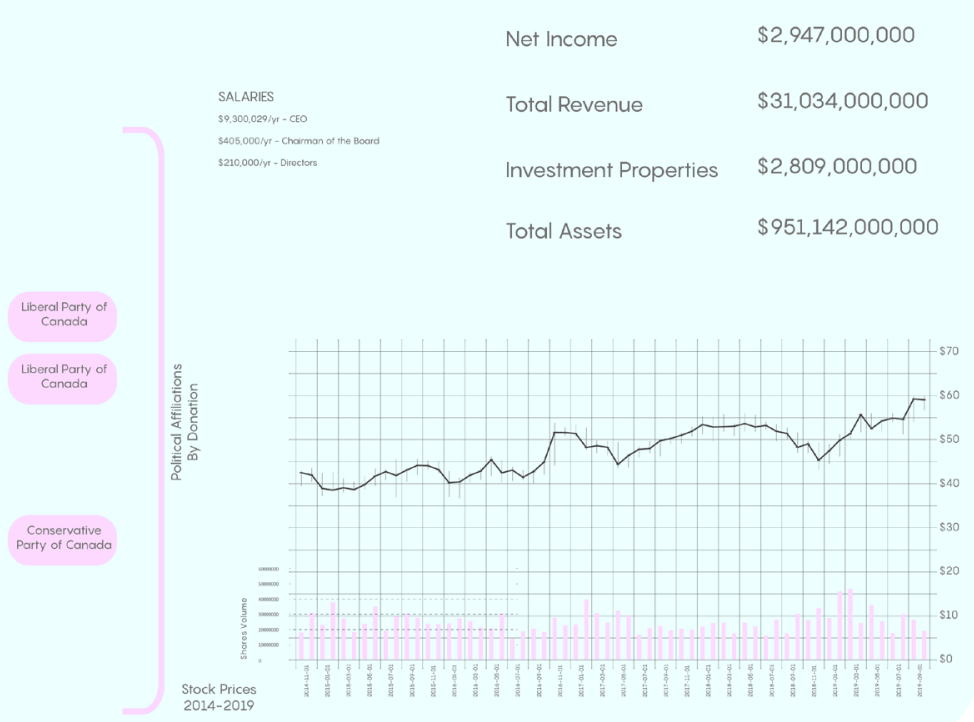

Conservative
Party of Canada
ANCHOR TENANTS

Sun Life

Insurance

$\$ 31,034,000,000$

Swiss Re Reinsurance

Reinsurance

Revenue $\$ 31,942,000,000$

$\frac{\mathrm{JLT}}{\text { nnsurance }}$

Revenue $\$ 1,386,000,000$

Crawford \& Company

Claims Management

Revenue $\$ 1,017,000,000$

Lennard Commercial Realty

Realty, Brokerage
FINANCIAL [USD)

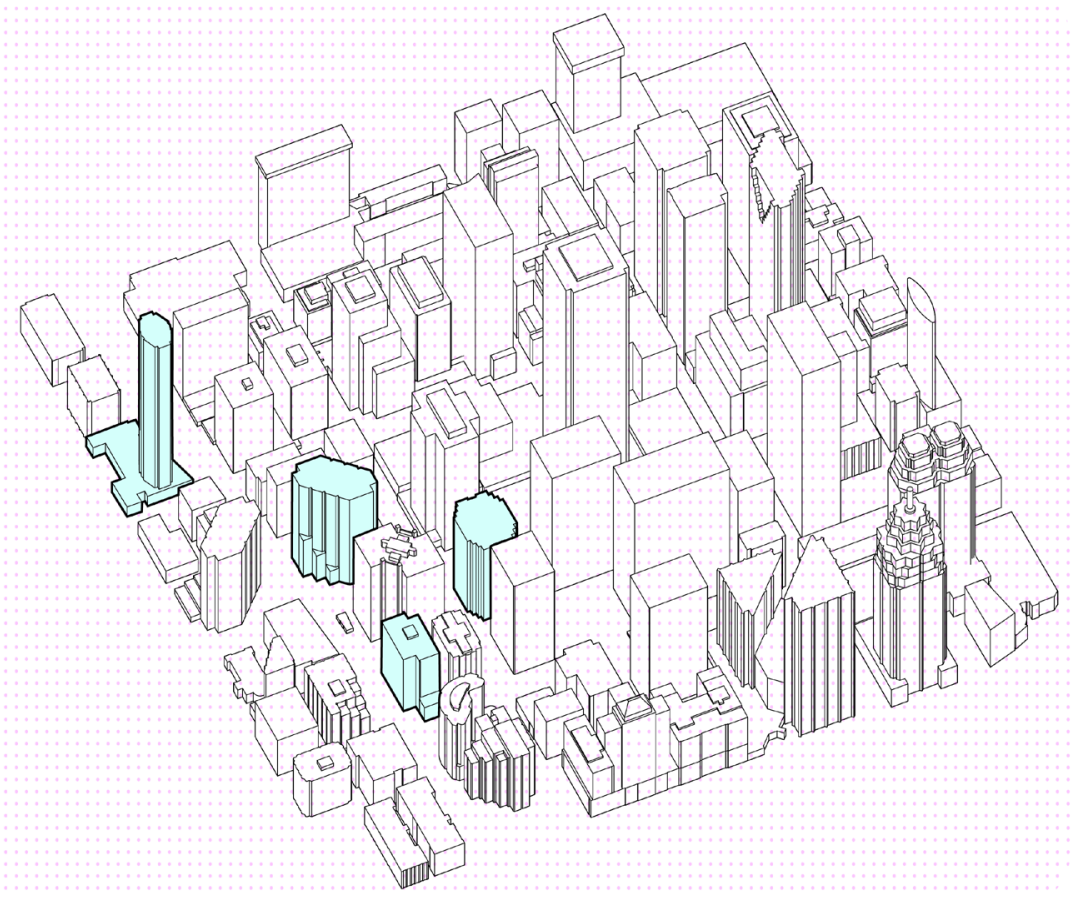

$\operatorname{Img} 10$ | Sun Life

Analysis of the finances of the building owners. 


\section{ONTARIO TEACHERS' PENSION PLAN}

CADILLAC FAIRVIEW

\section{PRIVATE COMPANY}

BOARD OF DIRECTORS

Steve MCGirr
cominn

Bill Chinery

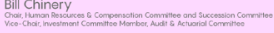

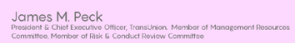

Cathy Cranston

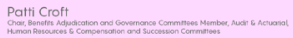

Lise Fournel

Gene Lewis

M. George Lewis

John Murray

Kathlen O'Neill

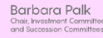

Daniel Sullivan

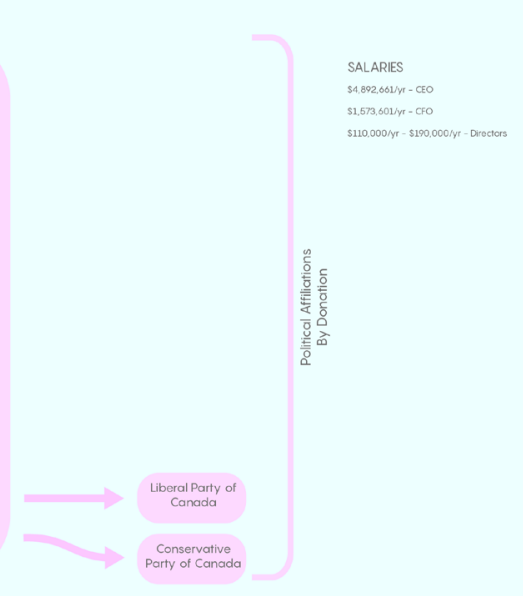

FINANCIAL [CAD]

Net Income

$\$ 5,200,000,000$

Total Revenue

$\$ 2,104,000,000$

Investment Properties

$\$ 27,500,000,000$

Total Assets

$\$ 191,100,000,000$

$$
\$ 191,100,000,000
$$

\section{ANCHOR TENANTS}

Toronto Dominion Bank

Bank

Revenue $\$ 38,834,000,000$

WeirFoulds LLP

Law Firm

Mc Carthy Tetrault

Business Law Firm

$A G F$

Asset Management

Revenue $\$ 471,126,000$

Folger Rubinoff LLP

Law Firm

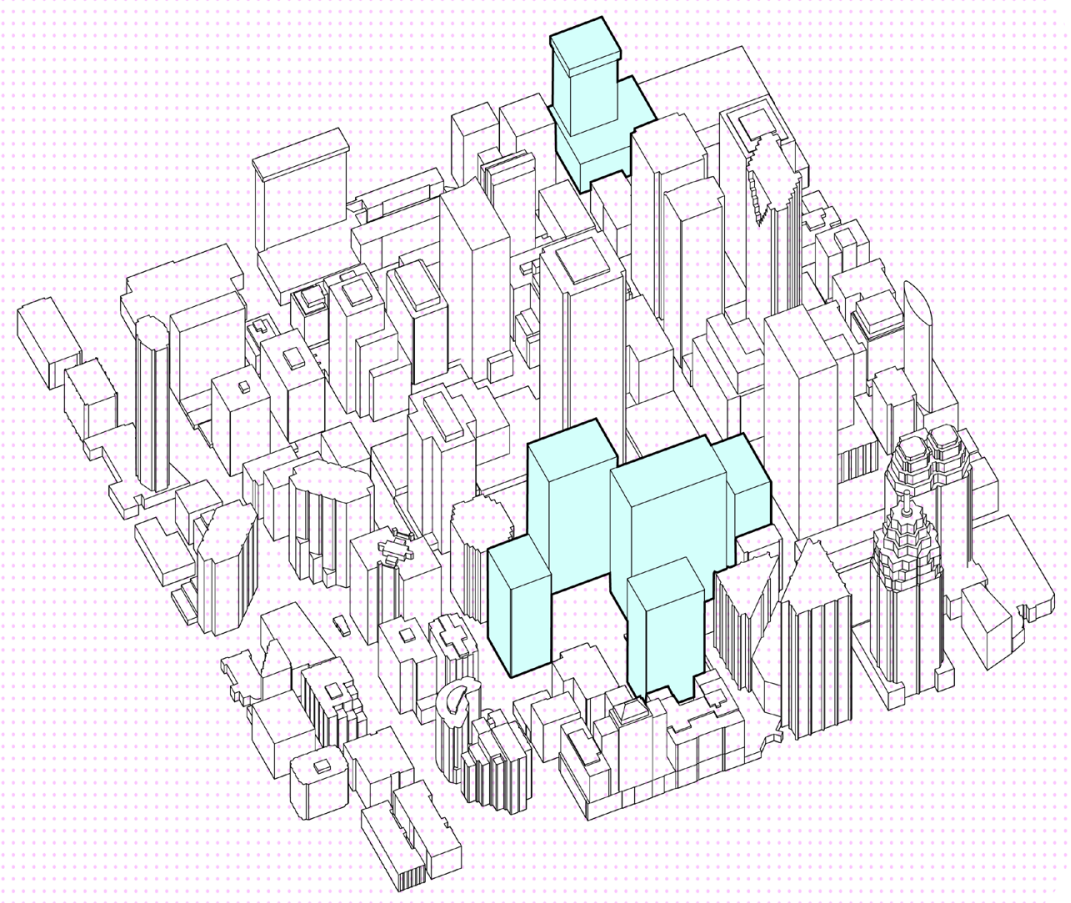

Img 11 | OTPP

Analysis of the finances of the building owners. 


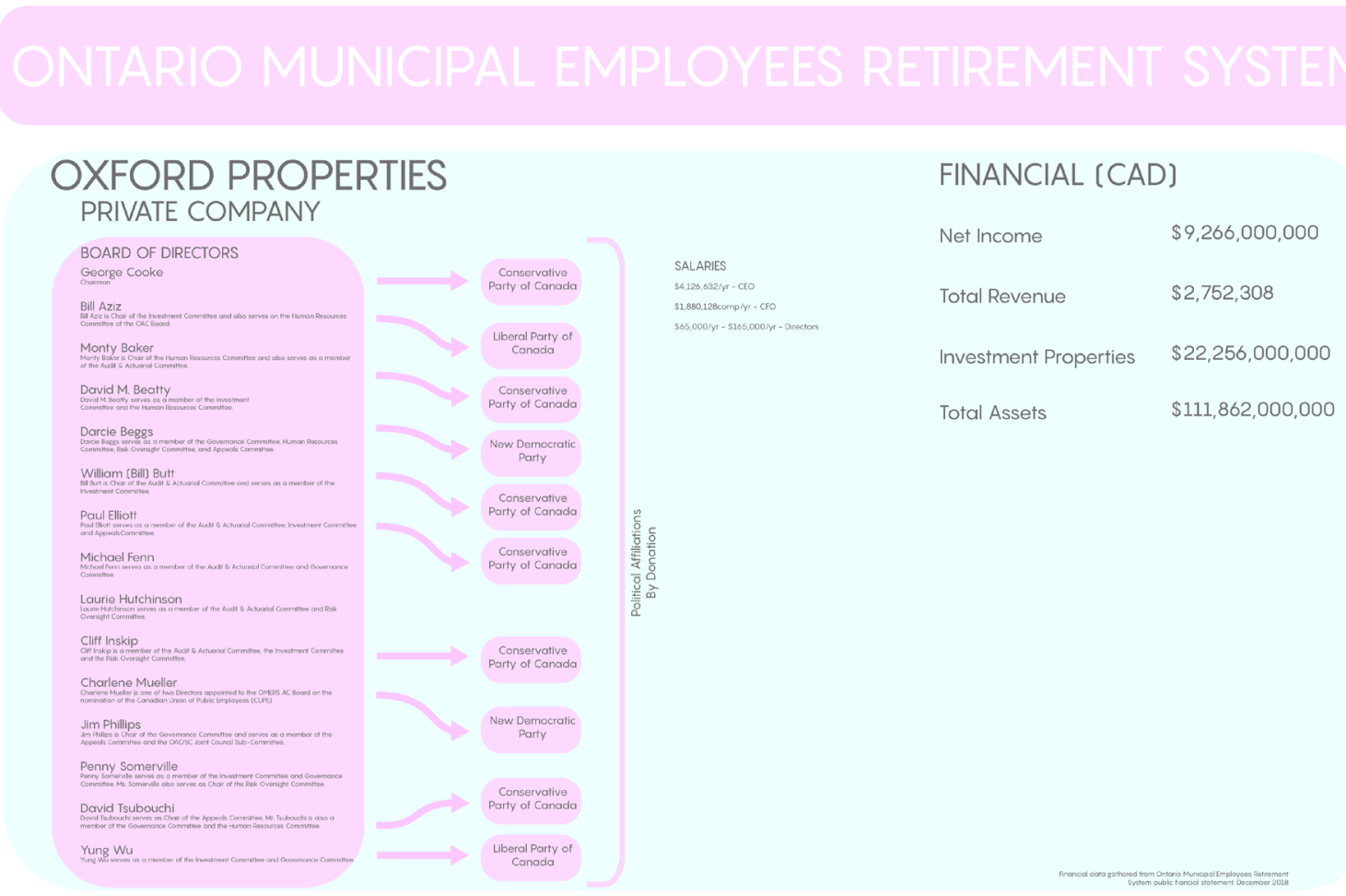

\section{ANCHOR TENANTS}

VALE Canada Limited

Subsidiary of Mining Company

Revenue $\$ 36,575,000,000$

EY

Professional Services

Revenue $\$ 34,800,000,000$
2018

Sprott Asset Management

Asset Management \& Resource Financing

Revenue $\$ 109,269,000$
2018

Centerra Gold:

Gold Mining

Revenue $\$ 1,129,000,000$

Lerners LLP

Law Firm

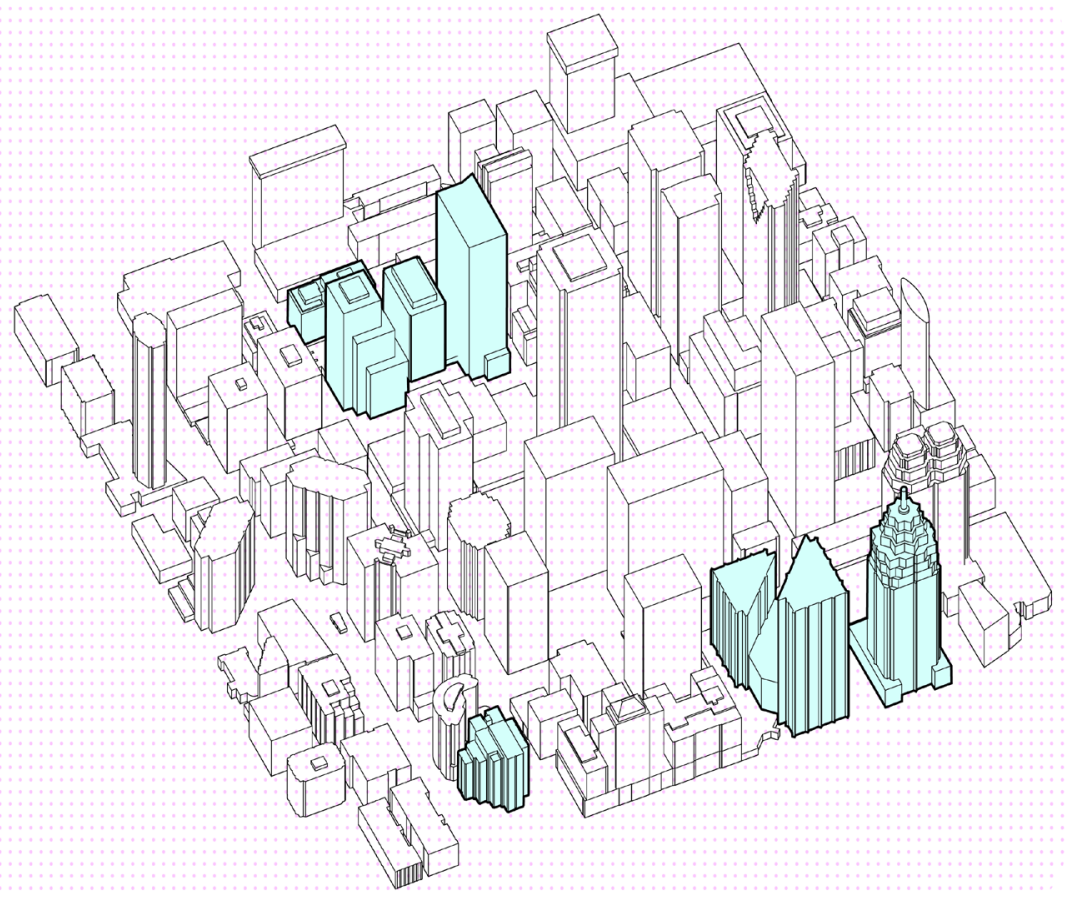




\section{BC INVESTMENT MANAGEMENT CORPORATION}

\section{QUADREAL PROPERTY GROUP} PRIVATE COMPANY

BOARD OF DIRECTORS

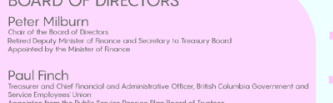

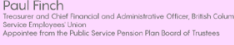

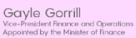

Donna Lommer

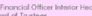

Karen Maynes

Ken Tonnor

Konter Tannar

Sheila Taylor

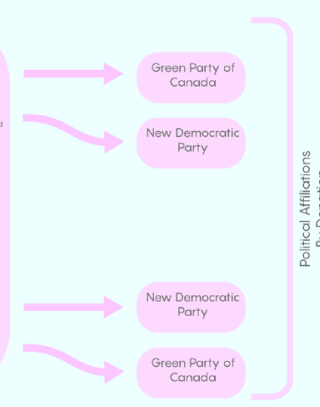

\section{FINANCIAL (CAD)}

SALARIES Net Income $\quad \$ 4,555,000$

S3 $315.030 / y r-C F O$
S1.880.128comp/yr - CFO

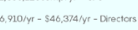

Total Revenue

$\$ 416,563,000$

Investment Properties

$\$ 3,100,000,000$

Total Assets

$\$ 129,400,000,000$

\section{ANCHOR TENANTS}

Bank of Nova Scotia

\section{Bank}

Revenue $\$ 29,000,000,000$

Amazon

Online Retailer

Net Income $\$ 10,073,000,000$

Cassels Brock \& Blackwell LLP

Business Law

GMP Richardson Wealth Management Wealth Management

Revenue $\$ 290,100,000$

MCAP Mortgages

Mortgage Finaincing

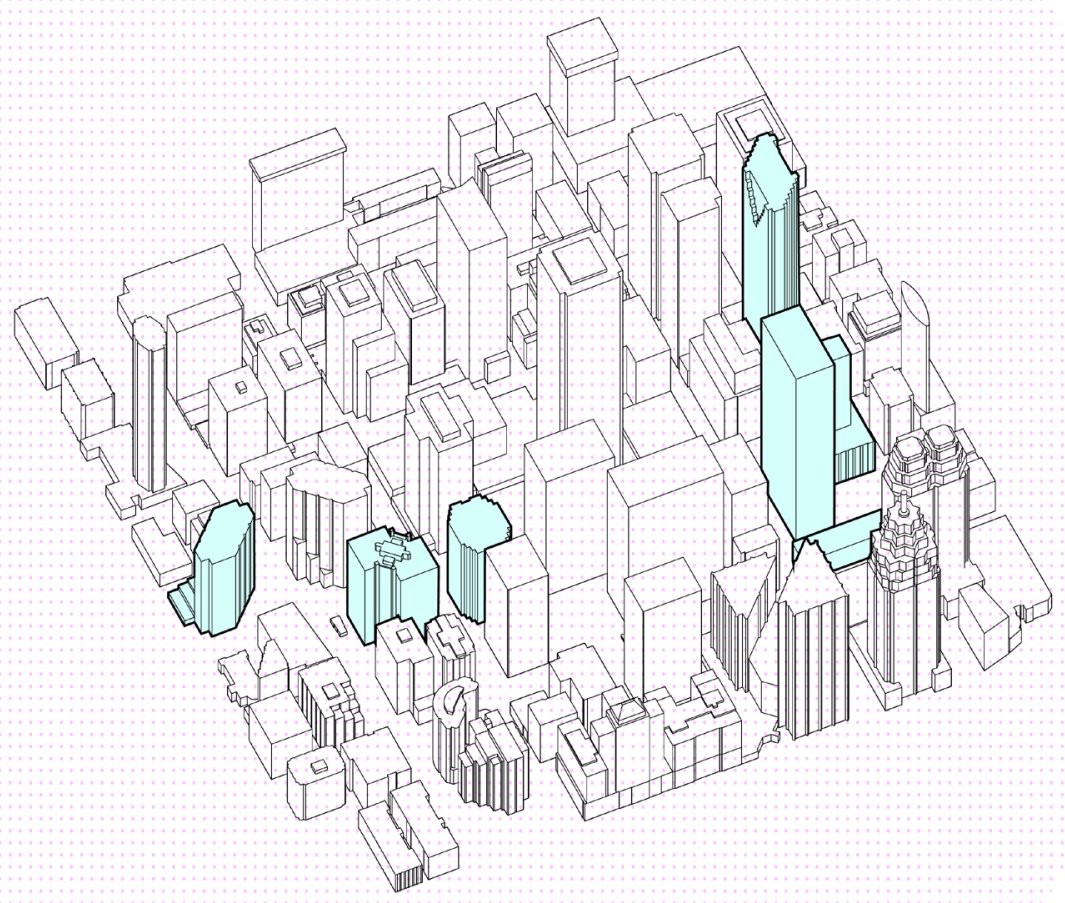


Through my personal experience of the site, despite its density and convenience, this district does not encourage wandering or leisure activities and remains unwelcoming to the alternate publics. Temporary inhabitation of the neighbourhood by those that do not work there is uncommon due to the lack of publicly accessible, private or intimate spaces. The buildings become less distinct pieces of architecture and the neighbourhood becomes an unremarkable ; the financial district is composed of the fabric these large buildings create. The desire to have a unique experience in this scenario is drowned out by scale, density and dullness.

Publicly accessible spaces are tailored to economically driven and consumerbased corporations creating a hostile and uninviting neighbourhood. The exclusionary elements of the area are exemplified in the high levels of security and surveillance, the lack of community oriented spaces, the businesses/restaurants specialized for high end clientele and through the design of outdoor space. Privately owned public spaces create a series of small parklets, outdoor fountains and alcoves used by primarily by office workers to eat lunch. The parklets, are scarcely planted and hardscaped, they provide no long-stay appeal. These outdoor spaces while appearing public, remain in the control of the property managers and the security staff they employ. The lack of public amenities, affordable eating options and uncomfortable benches imply the loiterer must move through the space quickly. The interests of the companies that run the district are economic in nature, their decisions are dependent on the most profitable outcome. The most profitable outcome is only beneficial to the dominant public. 


\section{5}

\section{DESIGN PROCESS}

The research-by-design methodology of the thesis progressed from an initial site analysis and questioning of the power dynamics of the urban condition to a series of designs that addressed these concerns. The initial issue considered the exclusionary and corporate design of the district. A first approach was for the public to occupy traditionally privatized space, most notably the temporary vacant floors in the existing buildings. Unleased spaces were mapped and visualized to represent the possibility of non-office workers occupying unleased floors in skyscrapers. The identification of these spaces was abstracted as the office vacancy rates for the neighbourhood were well documented by the CBRE Commercial Real Estate Services Canada, yet the exact locations of these openings are not documented for the public record. These occupations were decided to be temporary in nature as they followed the cycles of the leasing market. Phase two of the project aims at articulating these new programs on the external face of the buildings. A series of elevated connections were designed that would link these alternative programs. This approach was first expressed in Colloquium 2. This design approached intensification and programmatic overlaps almost completely within the existing constructed architecture and was therefore dependant on the structures and its operations that it simultaneously aimed to subvert. 


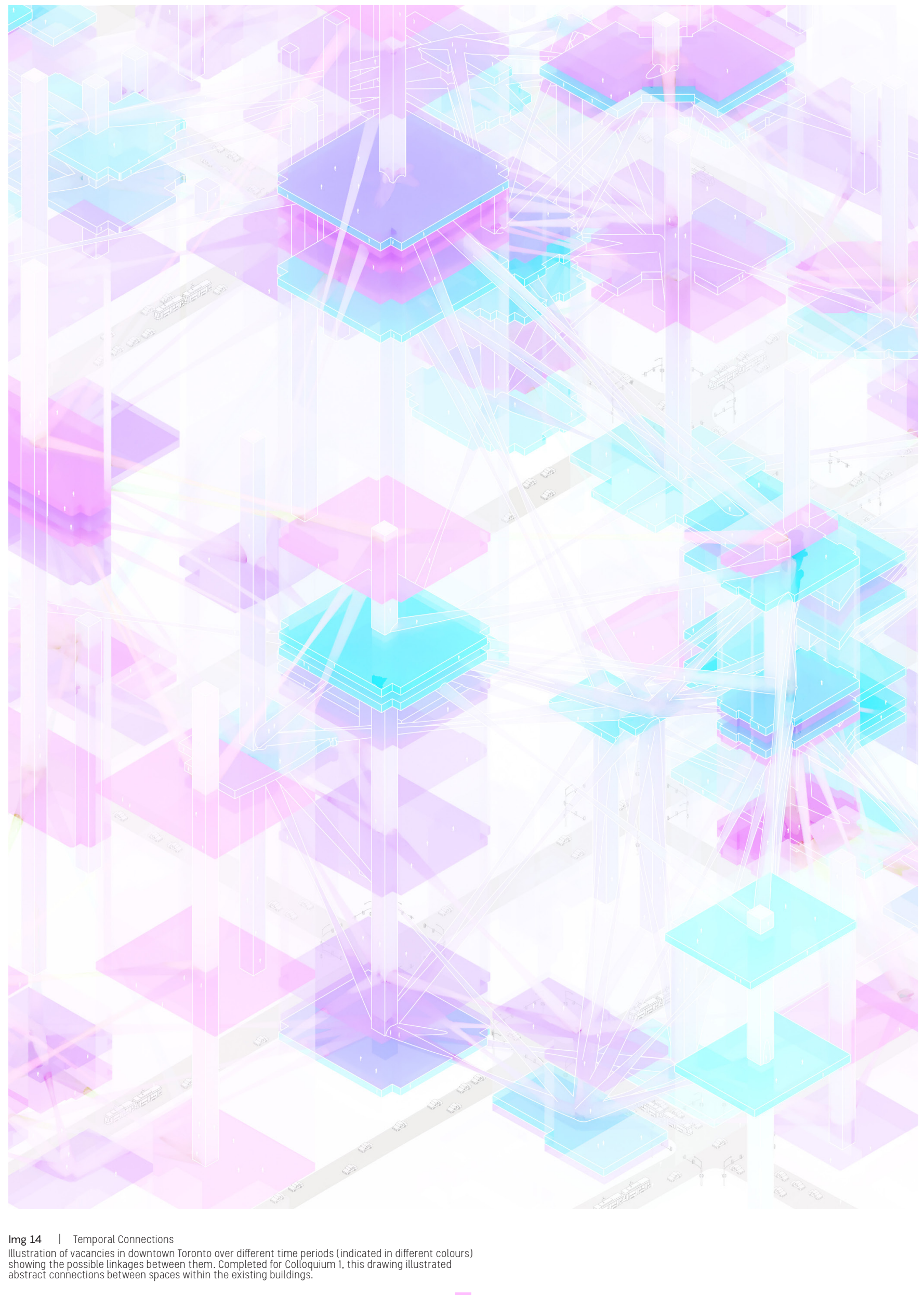




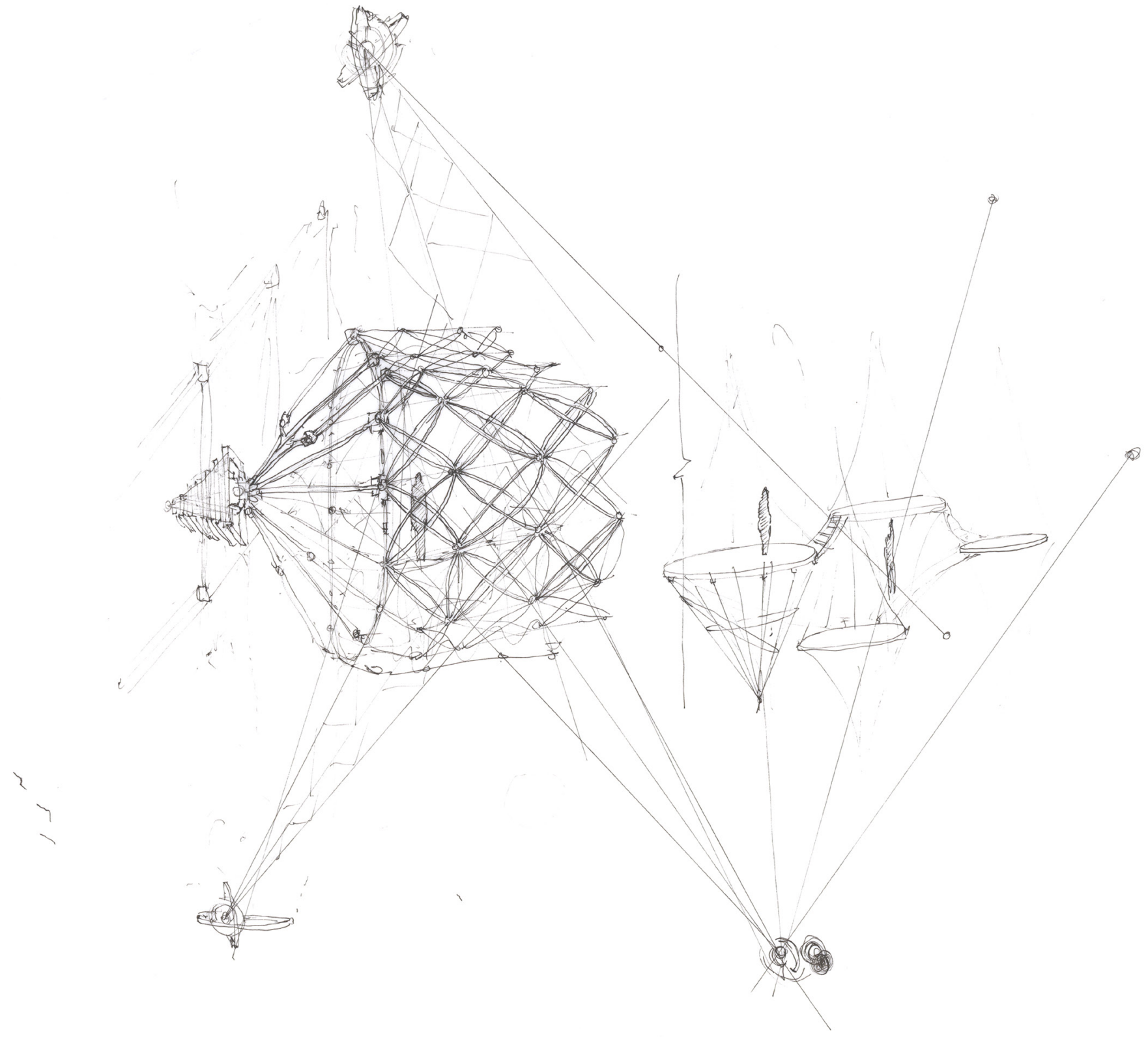

Img 15 | Tensile Connection

First sketch of the possible tensile structure that could attach to the existing buildings on the site 


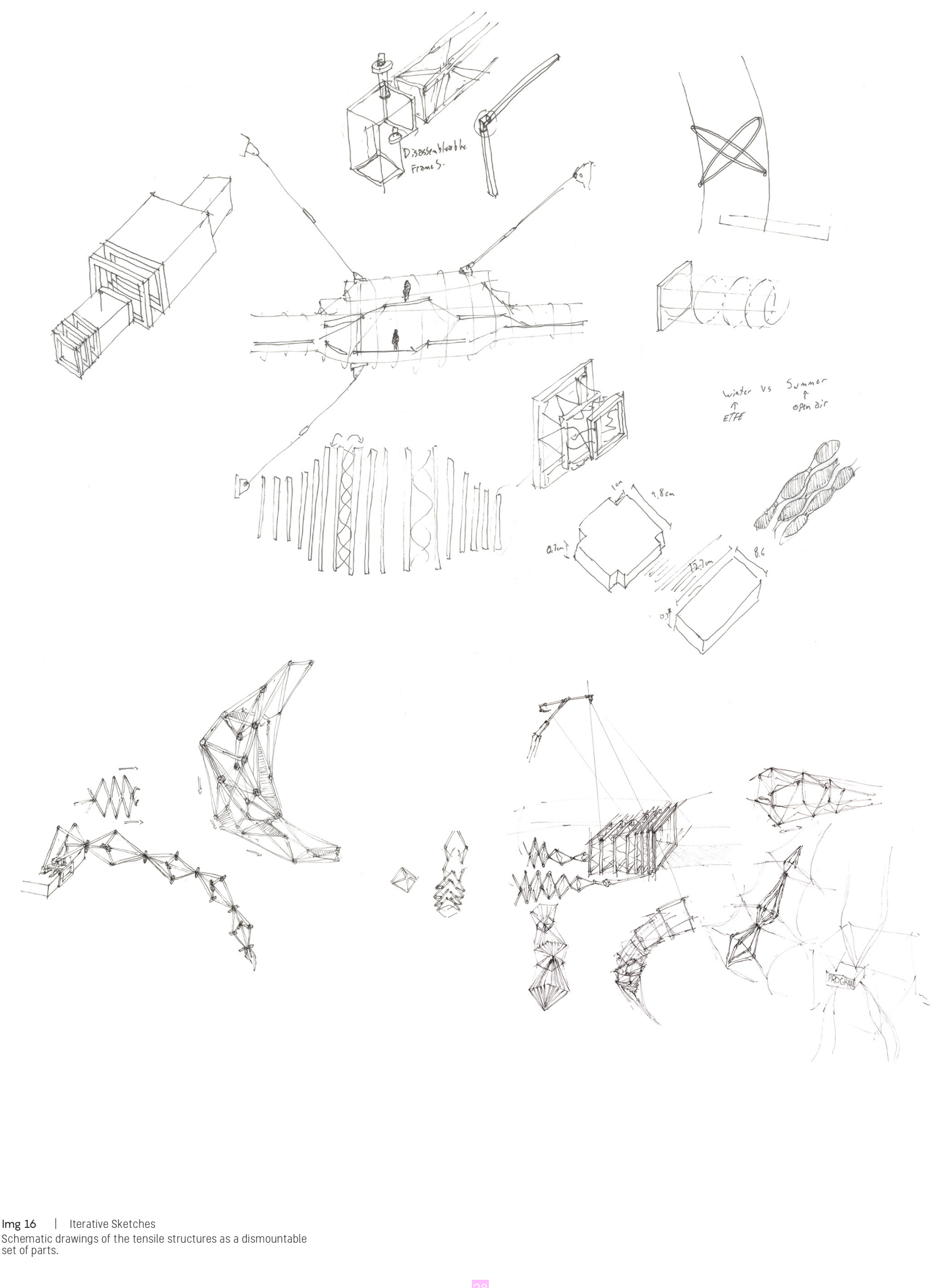



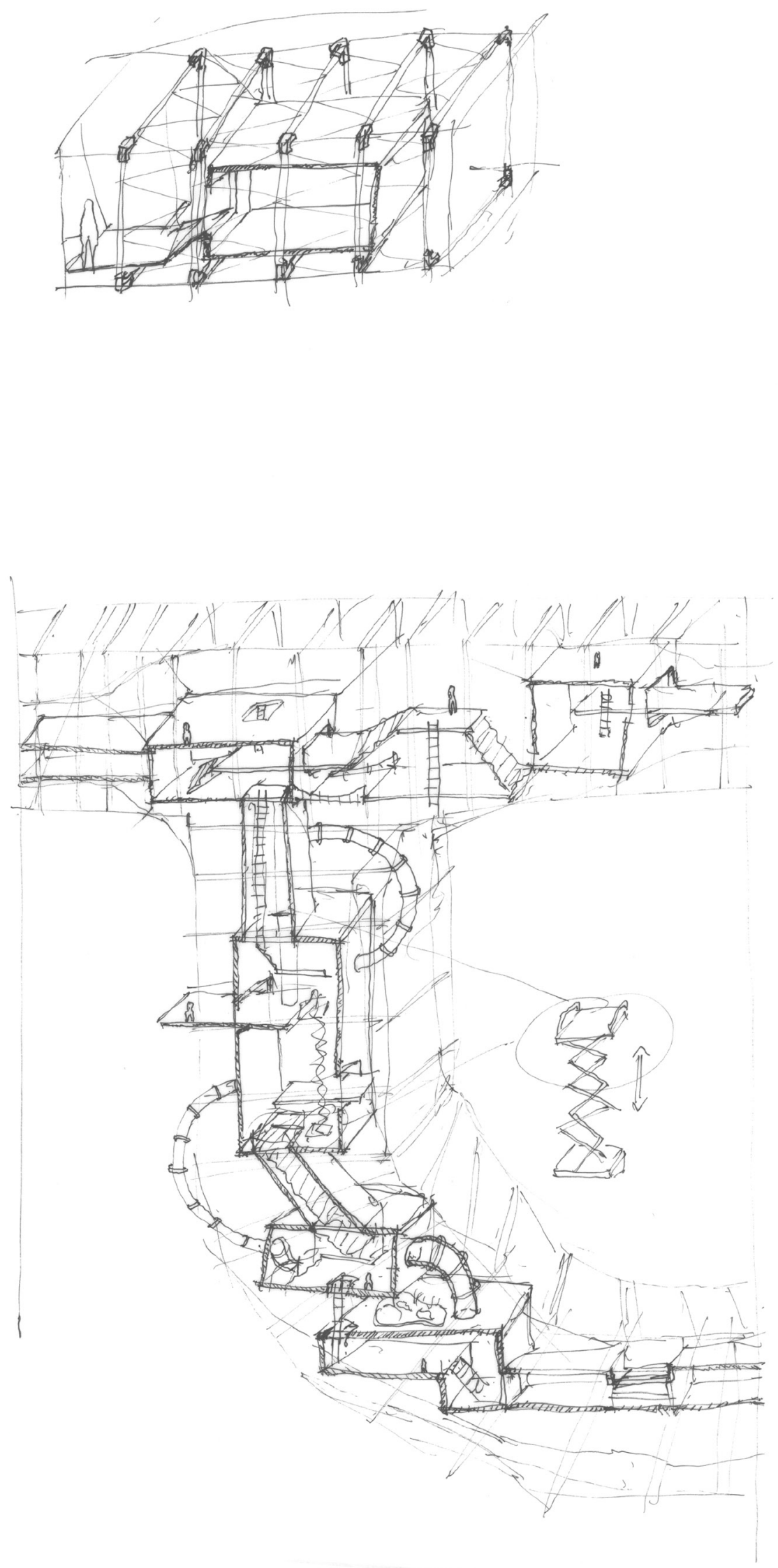

Img 17 | Vertical Inhabitation

Original sketch of the circulation through the tensile framework. Further investigations proved a more horizontal approach to the tensile system would be more efficient and suit the green space program. 


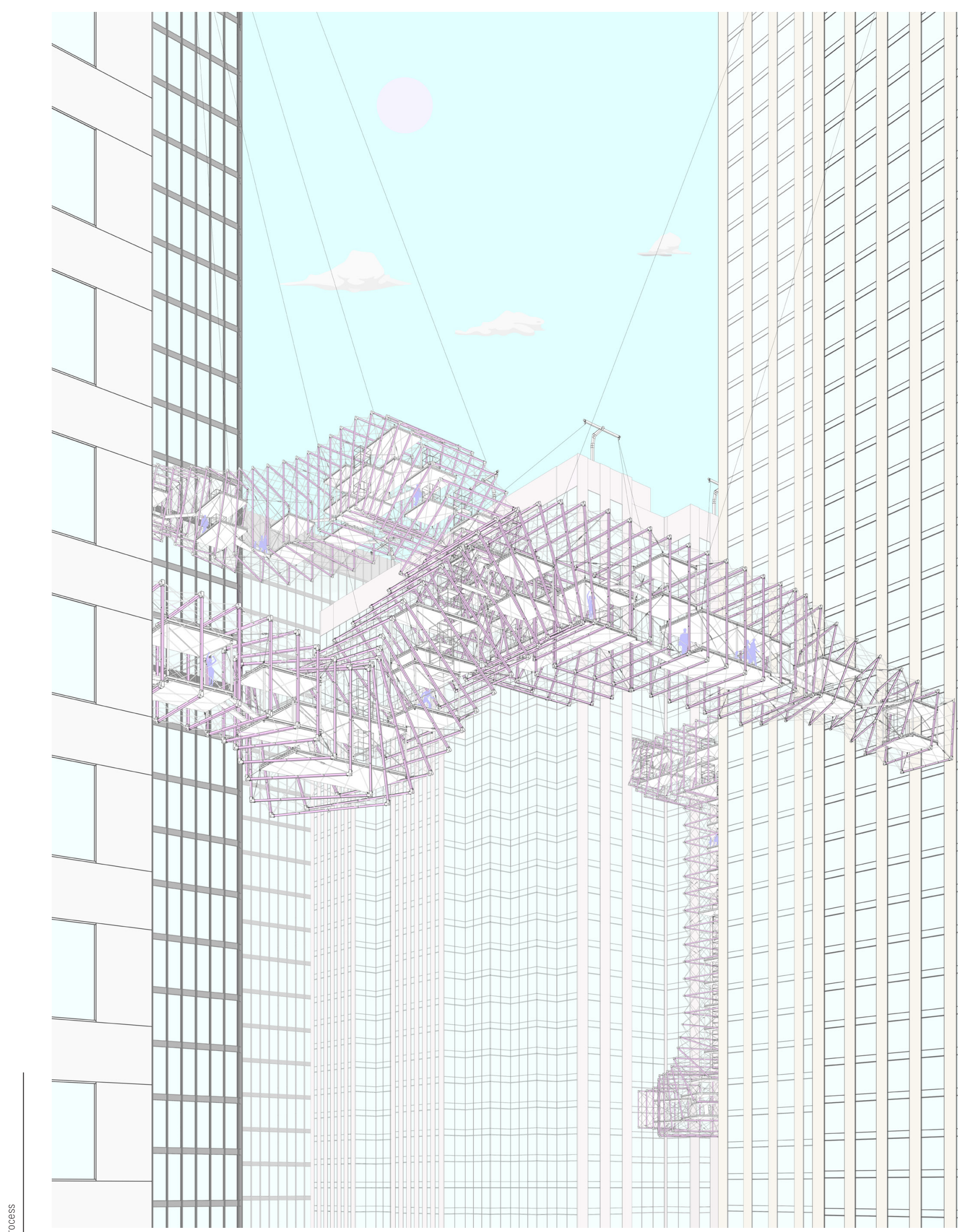

Img $18 \quad$ | Hanging Structures

Illustration of the tensile system as it becomes a framework that propagates throughout the site. This iteration of the tensile system was more horizontal yet it neglected the green space program in favour of a
green space program. 
Following this initial design approach, public and private spaces were further studied. Ownership and power were expanded upon and researched. This led to the finding that most large buildings in the area are owned by the same five multi-billion dollar corporations. The companies and their subsidiaries publish their financial data and the salaries of their top board members and chief executive officers, indicating that those who have influence over the ownership and operation of the space are held accountable for the financial success of the most profitable corporations in the city.

From these considerations, connections and urban green spaces were explored in an elaboration of the next phase of design. The abstract linkages presented at Colloquium 1 were expanded upon to create elevated park spaces to be occupied by both the subordinate and dominant publics. The connecting armatures were designed to be temporary demountable structures that shift with the programmatic and leasing needs of the neighbourhood. This design aimed to occupy the space above the street and combine a different population with the existing workers in the district. This second iteration of design did not identify the alternate publics, only specified space for this nebulous group to occupy. This ambiguity led to a lack of specificity in the program. The concept of the subordinated publics was ambiguous, their only defining trait was that of those opposed to the dominant publics. 


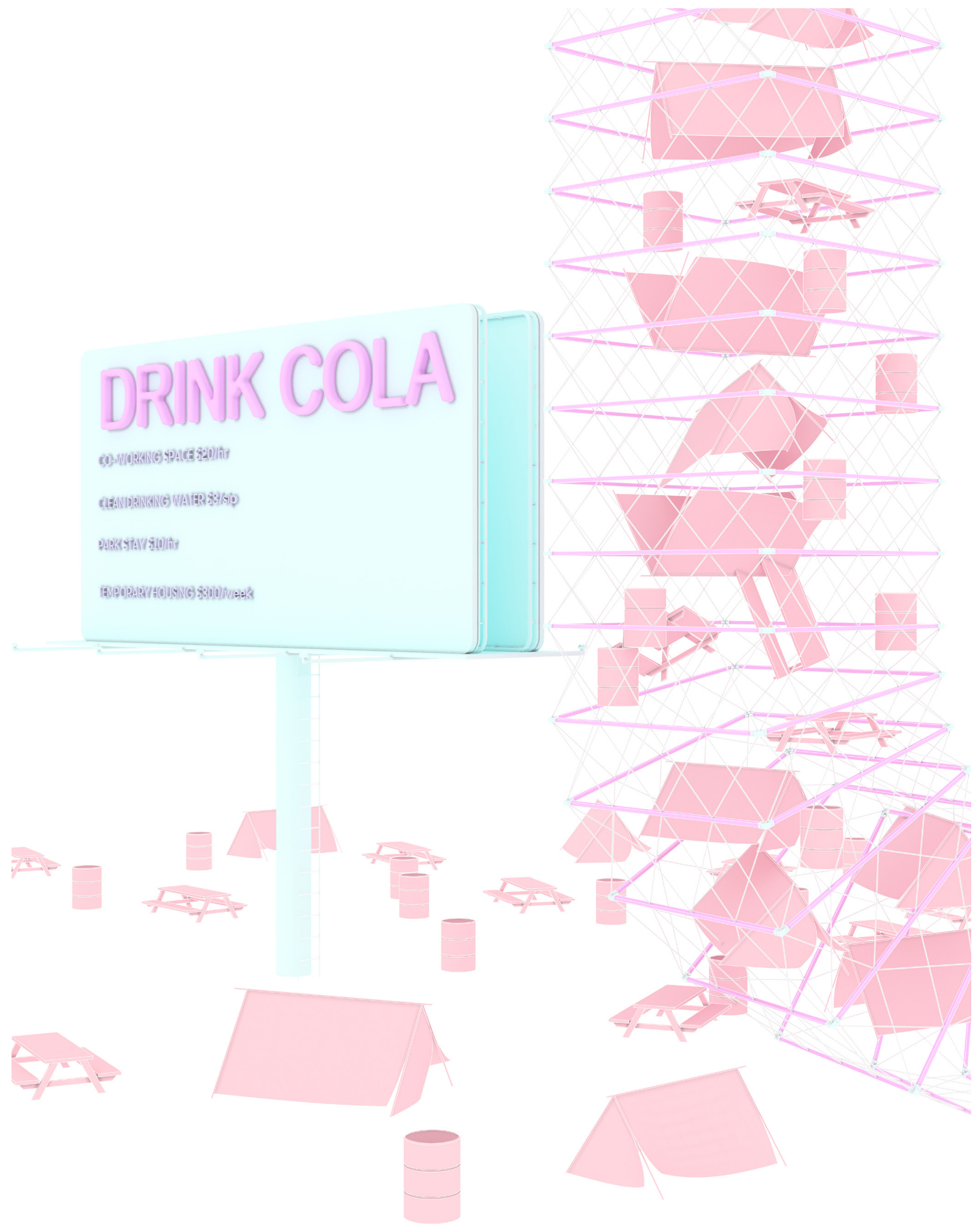

Img 19 Drink Cola

Advertisements thrive in a time without livable housing. The nature of space and housing is questioned, billboards tower over informal 
24 Yoos, Jennifer, et al. Parallel

Cities: The Multilevel Metropolis.

25 Ibid. pp. 36

26 Ibid. pp. 135
The research-by-design methodology initially analysed Rem Koolhaas' ideas on Bigness and The Staging of Uncertainty and shifted them to adapt to the varying publics of Toronto. The design research became a redefinition and exploration of the possible spatial tactics that speculated a new Bigness that could house uncertain elements. This research shifted my thoughts on the Staging of Uncertainty. Moving away from Koolhaas' downtown athletic club, where uncertainty occurs on distinct separate floors, the uncertainty of the thesis blurs the boundaries vertically and horizontally.

This conception of the city, as a series of elevated programs, is situated within its own urban history. The idea of a multilevel city and its social potential has been extensively theorized, both from a capitalist and socialist perspective. The Soviets saw elevated paths and connectivity as Social Condensers. Absorbing many ideas from French Social Utopians, the Soviets saw the communal potential of these programmatic overlaps. ${ }^{24}$

The Soviet multilevel cities were designed to be opposed to the existing capitalist urbanism that removed the horizontal circulation, favoring the vertical skyscraper. ${ }^{25}$ The Soviet Constructivists relied primarily on Modernist forms and symbols to create new social spaces. The spatial and programmatic relations that the Constructivists aims to create demanded a new design. "New social relations demand a new space" 26

The design of new social spaces required a different architecture than the traditional capitalist downtown. I remain skeptical of the utopian visions of the multi-level urbanism as a system that solves all societal issues, yet the notions of program hybridizations are important for this thesis as they illustrate the usefulness of these moments of overlapping community space. 


\section{6 \\ PROGRAM}

27 SimplyAnalytics (2019).

Environics Daytime Population CA.

Retrieved January 17th, 2020, from

SimplyAnalytics database.

28 "G0 2020 Strategic Plan." 2019

http://www.ontla.on.ca/library/,

repository/mon/25005/309721.pdf.
The programmatic requirements of the site were determined by an analy sis of demographics and needs of those who reside there and those who commute from within the city and the adjacent suburbs. The needs were arranged to supplement the existing community services in the neighbourhood. Data examined from Environics Analytics for the financial district (census tract 0014.00) showed a 7163\% increase in day time population, jumping from 2031 residents at night to 149,772 people occupying the space during the day time hours. The change in daytime occupation is significantly lower in the rest of the city. The seven surrounding districts (census tracts 0011.00, 0012.03, 0013.01, 0015.00, 0034.02, 0035.00, 0036.00) show a 369\% change and the city of Toronto shows a $105 \%$ change. ${ }^{27}$ A combination of Statistics Canada census data and commuting data from G0 transit, creates a more accurate depiction of the occupants of the district. 1.2 million people commute to Toronto during peak hours, Union Station sees 190,000 peak hour arrivals via the G0 Train system, and 150,000 work in the financial district. Of those commuting for work, $67.7 \%$ arrive by automobile. ${ }^{28}$ The financial district relies heavily on commuters to thrive, this reliance has created a downtown that lacks public amenities such as schools, nurseries, community centres and proper park space. 
29 Statistics Canada. 2017.

5350014.00 [Census tract], Ontario and Toronto [Census metropolitan area], Ontario (table). Census Pro-

file. 2016 Census. Statistics Ca

Catalogue no. 98-316-X201

Ottawa. Released November 29.

Ottawa. Released November 29

https://www12.statcan.gc.ca/

census-recensement/2016/

$\mathrm{dp}-\mathrm{pd} / \mathrm{prof} /$ index.cfm? Lang=E

(accessed January 21, 2020).

30 City of Toronto. "Child Care \& Before-After School Program Locator." City of Toronto, 14 Nov. 2018, www.toronto.ca/community-people/children-parenting/ children-programs-activities/licensed-child-care/child-care-lo

centor/\#tocation=130 Adelaide St

$W \& l a t=43.649694 \& \operatorname{lng}=-79.383922$

31 Statistics Canada 2017 5350014.00 [Census tract], Ontario and Toronto [Census metropolitan area] Ontario (table). Census Profile. 2016 Census. Statistics Canada Catalogue no. 98-316-X2016001. Ottawa. Released November 29 2017.

https://www12.statcan.gc.ca/ census-recensement/2016/

$\mathrm{dp}-\mathrm{pd} / \mathrm{prof} /$ index.cfm? Lang $=\mathrm{E}$

(accessed January 18, 2020).

32 Kalinowski, Tess. "Who Lives and Works in the Financial Distric Toronto's 9-to-5 Neighbour-

hood." The Star, 15 Sept. 2015,

https://www.thestar.com/news/

gta/2015/09/15/who-lives-and-

works-in-the-financial-district-

torontos-9-to-5-neighbourhood. html.
In the site, education and child spaces are scarce, nor are education facilities for children and adults located near the district. The downtown population houses a large number of individuals with small children aged 0-9 without enough nurseries or daycares. ${ }^{29}$ There are 4 Daycare/Nursery/Preschools in the financial district, data provided from the city of Toronto indicates only 1 of the institutions as having availability in their preschool program, the other programs are full, or the data is incomplete. ${ }^{30}$ There are few elementary, secondary or adult schools within a reasonable distance of the neighbourhood. Individuals commuting long distances must find suitable accommodations for their children far from their place of work.

A majority of employment in the core is centered on Finance and insurance, Real Estate and Renting and Leasing, and Professional Scientific and Technical Services. ${ }^{31} 57 \%$ of the daytime residents of the financial district work in either finance or Real Estate Sectors. ${ }^{32}$ Speaking in terms of Publics, those belonging to those industries are considered in this thesis to be the dominant Publics as they represent a large majority and dictate the design of the space. The excluded Publics in the area are those that belong to the less numerous yet still present industries of Retail Trade, Healthcare and Social Assistance, Educational Services and Administrative, Waste Management and Remediation Services. Those that do not follow the strict daytime schedule of the finance industry find themselves in a district without hospitable amenities and leisure space. 
SimplyAnalytics (2019). Environic Daytime Population CA. Retrieved January 17th, 2020, from Simply -

Statistics Canada. 2017. 5350014.00 [Census tract], Ontario and Toronto lCensus metropolitan areal. Ontario (table). Census Profite. 2016 Census. Statistics Canada Catalogue no. 98-316-X2016001. Ottawa. Released November 29.

https://www12.statcan.gc.ca/ pd/prof/ndex.cim? lang=
Daytime Population

Household Population
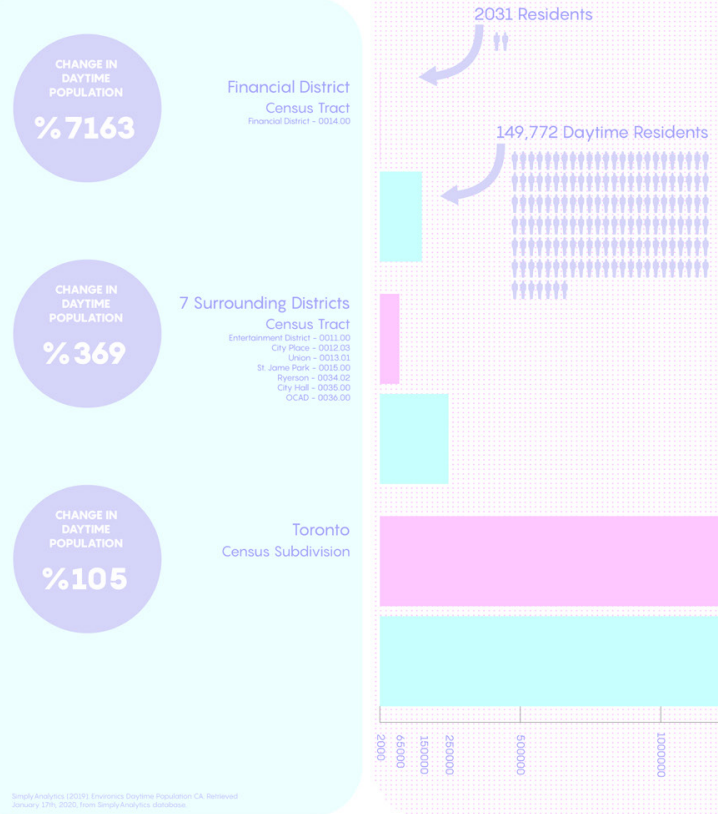

8 영

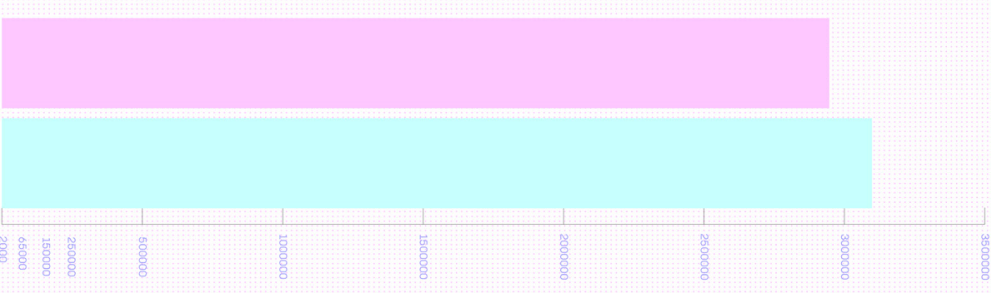

Img 20 | Daytime Population

Analysis of the of the daytime population.

$$
\begin{aligned}
& \text { POPULATION AGE } \\
& 85+\text { years } \\
& \hline 80-84 \text { years } \\
& 75-79 \text { years } \\
& 70-74 \text { years } \\
& 65-69 \text { years } \\
& 60-64 \text { years } \\
& 55-59 \text { years } \\
& 50-54 \text { years } \\
& 45-49 \text { years } \\
& \hline 40-44 \text { years } \\
& \hline 10-14 \text { years } \\
& \hline 55-39 \text { years } \\
& \hline 30-34 \text { years } \\
& \hline 25-29 \text { years } \\
& \hline 20-24 \text { years } \\
& \hline
\end{aligned}
$$

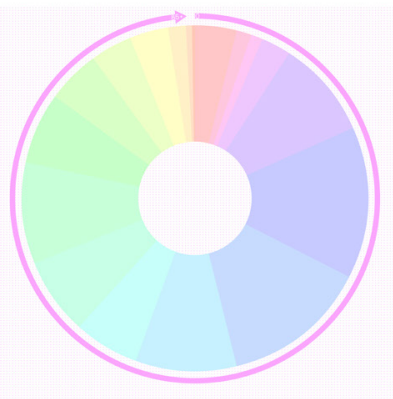

Financial District$$
\text { census tiod }
$$

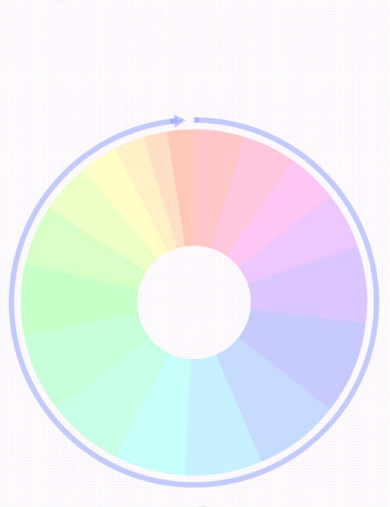

Toronto
cerow sonstison

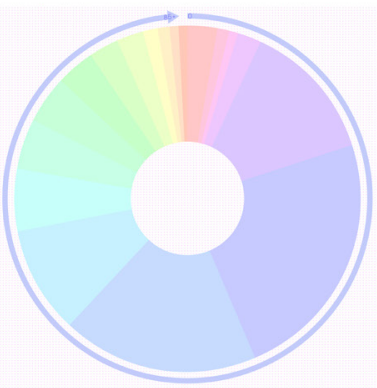

7 Surrounding Districts
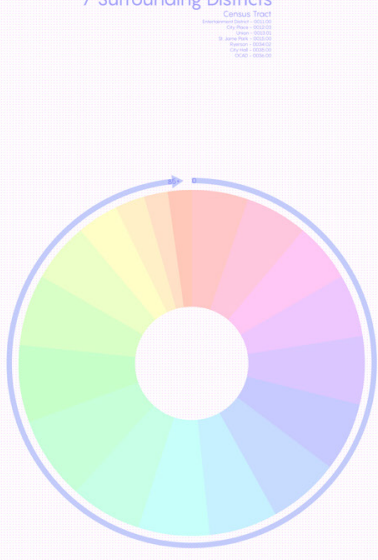

Feeder Suburbs

Img 21 | Population Age Population age breakdown. 
Kalinowski, Tess. "Who Lives and Works in the - Financial Distric hood." The Star, 15 Sept. 2015. https://www thestar.com/news/ gta/2015/09/15/who-lives-andworks-in-the-financial-districttorontos-9- to-5-neighbourhood

"Toward a Toronto Region Economic Strategy." 2014, https://ww bot.com/portals/O/unsecure/

Statistics Canada. 2017 5350014.00 [Census tract], Ontario and Toronto [Census metropolitan area], Ontario (table). Census Profile. 2016 Census. Statistics Canada Catalogue no. 98-316-X2016001. Ottawa. Released November 29 2017.

https://www12.statcan.gc.ca/ census-recensement/2016/dp$\mathrm{pd} /$ prof/index.cfm? Lang $=E$ (accessed January 18, 2020).
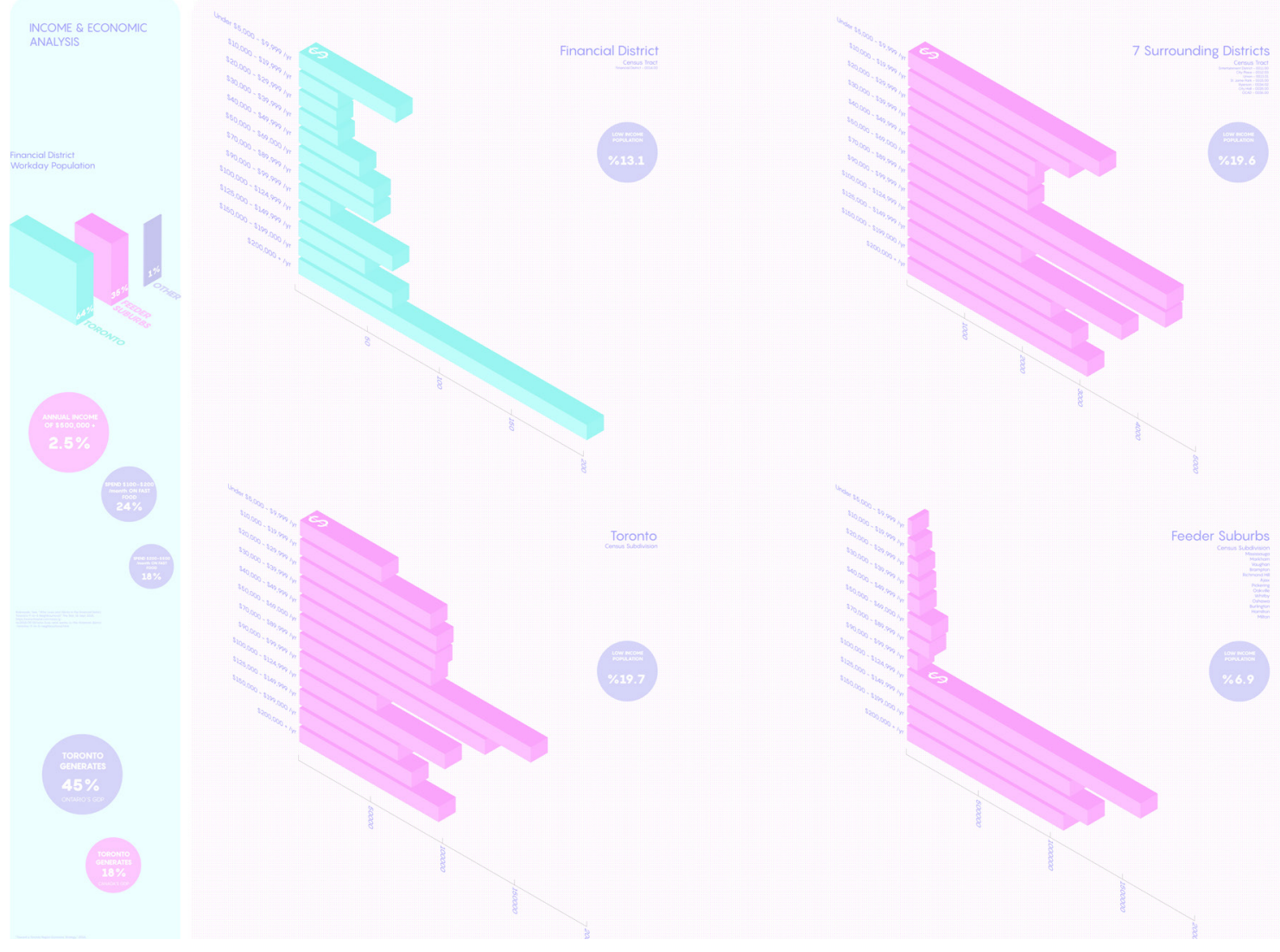

Img 22 | Income

Income breakdown and analysis.

“2016 Census: Education, Labour, Journey to Work, Language of Work, Mobility and Migration 5 Dec. 2015, https://www. toronto.ca/wp-content/uploads/2017/12/94ce-2016-Census-Backgrounder-Education-Labour-Journey-to-work-Language-Mobility-Migration.pd.

Statistics Canada. 2017. 5350014.00 [Census tract], Ontario and ToOntario (tabse 2016 Census Statistics Canad Catalogue no 98-316-X2016001. Ottawa. Released November 29.

https://www12.statcan.gc.ca/ census-recensement/2016/dp$\mathrm{pd} /$ prof/index.cfm?tang=E (accessed January 18, 2020).

Kalinowski, Tess. “Who Lives and Works in the Financial District. Toronto's 9-10-5 Neighbourhood." The Star, 15 Sept. 2015, https://www.thestar.com/news/ gta/2015/09/15/who-lives-andworks-in-the-financial-district-

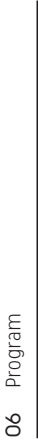

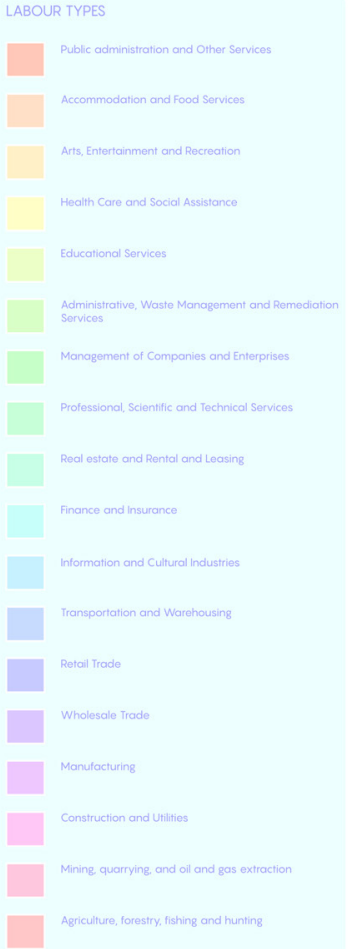
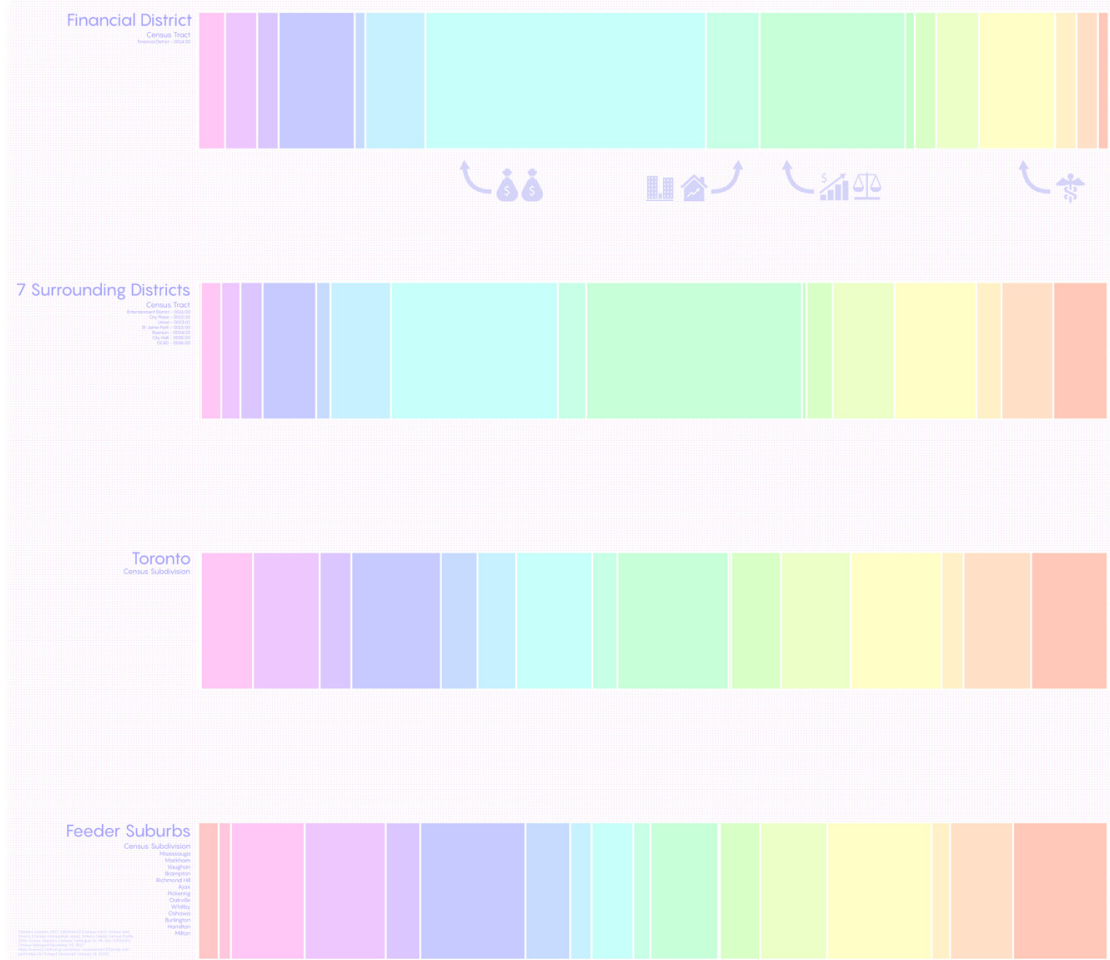

EMPLOYMENT

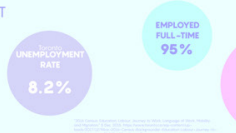

Img 23 | Labour Types

Categories of employment sectors. 
City of Toronto. "Education." City of

Statistics Canada. 2017. 5350014.00 [Census tract], Ontario and Toronto [Census metropolitan area], Ontario (table). Census Profile. 2016 Census. Statistics Canada Catalogue no. 98-316-X2016001. Ottawa. Released November 29, 2017.

https://www12.statcan.gc.ca/ census-recensement/2016/dp pd/prof/index.cfm?Lang= accessed January 19, 2020). enting/children-programs-activities/icensed-child-care/ child-care-locator/\#loca-

lion $=130 \% 20$ Adelaide $\% 20$ St $\% 20$ W\&lat $=43.649694 \&$ lng $=-79.38392$

Statistics Canada. 2017. 5350014.00 [Census tract], Ontario and Toronto [Census metropolitan area] Ontario (table). Census Profile. 2016 Census. Statistics Canada catalogue no. 98-316-X2016001. Ottawa. Released November 29,

https://www12.statcan.gc.ca/ census-recensement/2016/dp$\mathrm{pd} /$ prof/index.cm? Lang $=\mathrm{E}$ (c)

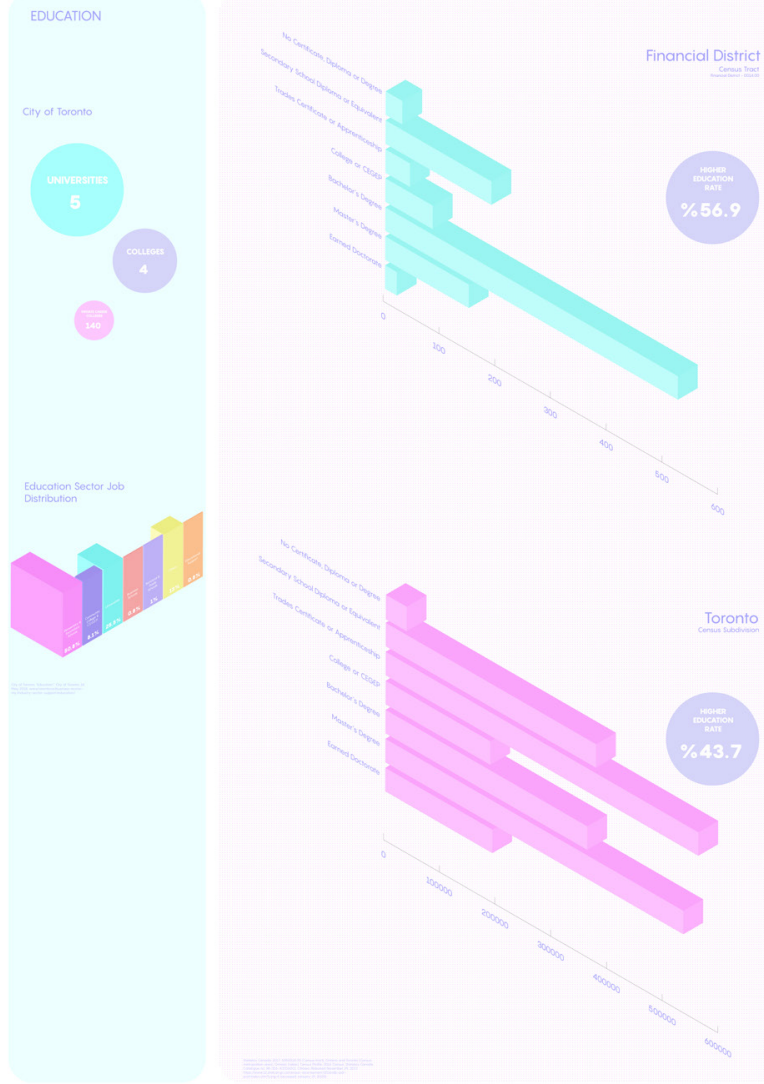

Img 24 Education

Education levels and availability.

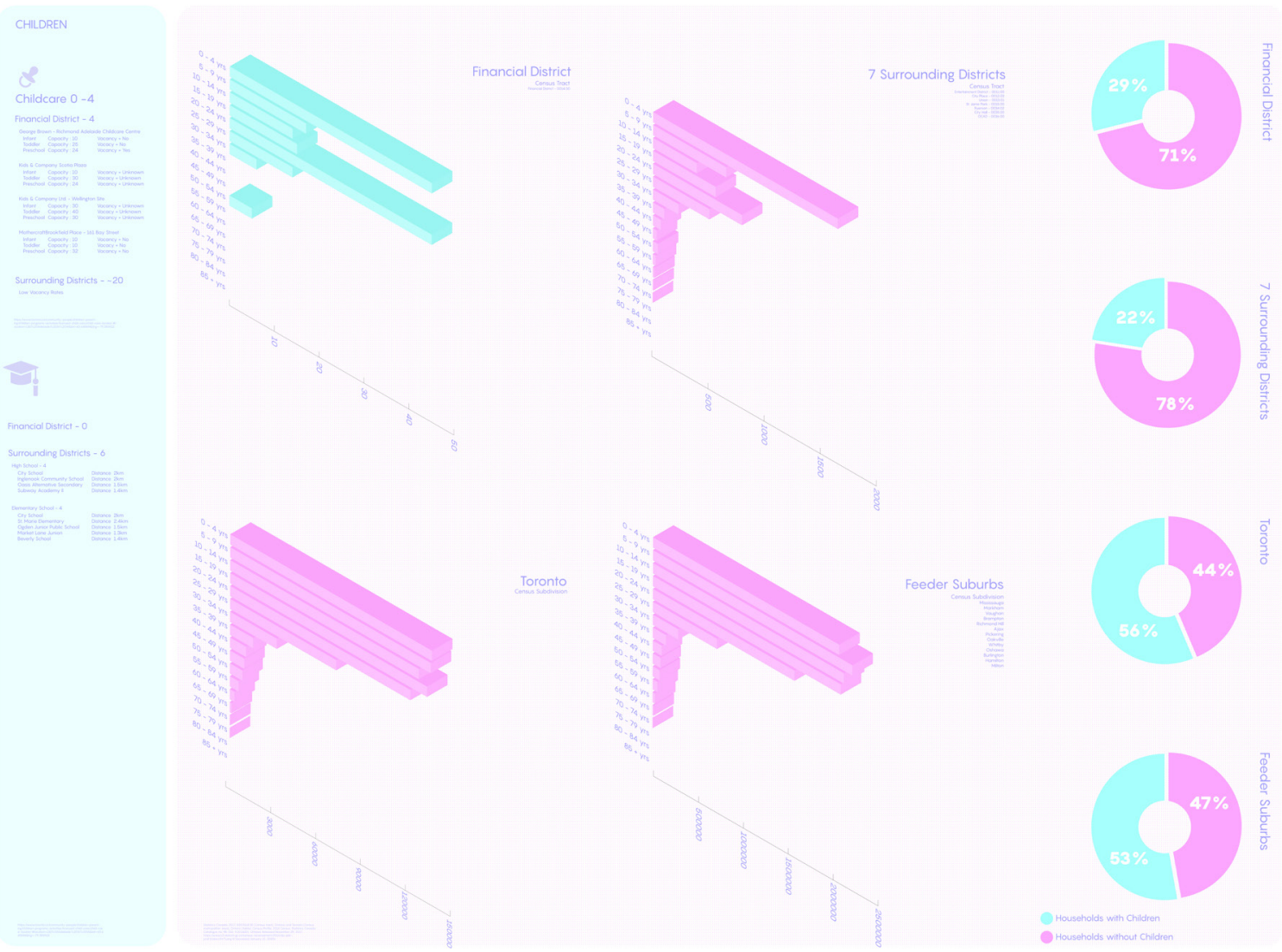




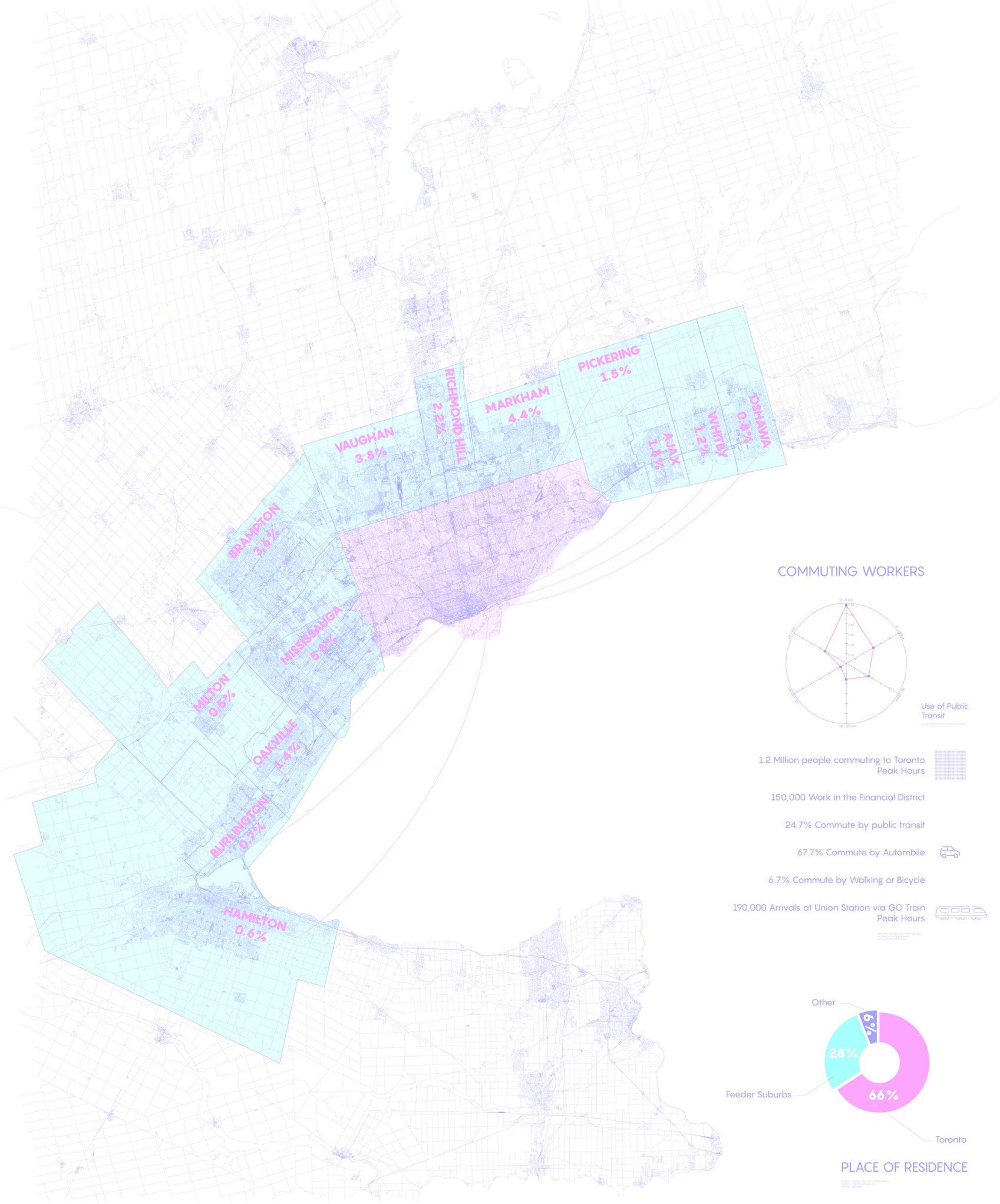

Img 26 | Commute Data

Analysis of the commutes of those working in Toronto.

Data gathered from:

Statistics Canada, 2016 Census of Population, Statistics Canada Catalogue no. 98-400-X2016325

"G0 2020 Strategic Plan." 2019, http://www.ontla.on.ca/library/repository/mon/25005/309721.pdf.

Savage, Katherine. "Results from the 2016 Census: Commuting within Canada's Largest Cities." Insights on
Canadian Society, 29 May 2019, https://www150.statcan.gc.ca/n1/pub/75-006-x/2019001/article/00008-eng.

htm\#moreinfo. 
From the analysis of demographics, needs and available resources, a list of programs emerged.

Offices : While the office-worker public has not been the primary focus of the thesis, to separate them from the non-dominant publics would recreate the initial problem with the site. The site, as it currently exists, separates offices from areas where the population resides. This separation is the catalyst for the homogenous downtown.

Market Rate Housing : Introducing habitation to the site increases variation in the publics found there. Introducing living spaces is important for the thesis as it directly addresses the issues of uniformity in the district. The creation of housing shifts the area away from its daytime and single use nature and promotes community living.

Social Housing : Those who work and live in the district do not exclusively occupy roles as high-ranking executives. The heterogeneity of the district relies heavily on the mixing and overlaps of publics. The introduction of social housing creates spaces that are not exclusively adapted to the affluent.

Elevated Green Spaces : Provides leisure areas and creates suspended connections between programs. The elevated spaces provide alternate methods of circulation and moments of repose. 
Community Centres: Social space is important to fostering community and ownership of the neighbourhood. This nebulous program encompasses a wide variety of programs open to all.

Library

Amphitheatre

Basketball Court

Pools

Steam Rooms

Squash Courts

Gymnasiums

Playgrounds

Skateboard Park

Music Performance Space

Schools : Elementary through Secondary for children, and adult learning spaces during the off hours. Eliminates the need to commute to different parts of the city for education

Childcare / Nurseries : With a growing number of households with young children, increasing the amount of childcare facilities in the neighbourhood facilitates the lives of the parents. 


\section{7 \\ REALIZATION}

The design proposals are time-based processes that occurs at varying scales with different levels of cooperation with the existing corporate structure. These different design schemes work in union to achieve the common goal of adapting the existing Bigness of the financial district of Toronto to better suit non-dominant publics through the Staging of Uncertainty. The new programs adopt the large spaces of Bigness in the retrofitting of existing structures and the building of new ones. New transitory programs are created to shift with the needs of the publics. The design follows three phases: the first phase occurs informally through the occupation of vacant spaces in the skyscrapers, the second phase erects transitory armatures to create park space and connectivity in the neighbourhood, the third and final phase constructs a series of new-build mixed use towers to introduce community and a mixing of programs.

The phasing of the three strategies is not fixed, the design elements do not occur on a set schedule or follow an established order of implementation. The framework that these strategies create is not driving towards a predetermined end condition, instead the designs negotiate with time, the public and the programs to create a system that shifts with the transient occupants. Multiple instances of the phases will be happening simultaneously to address the programmatic needs of the publics. The future of the city is difficult to determine as it is in constant flux, the design speculates a series of strategies that occur over time within the city. 


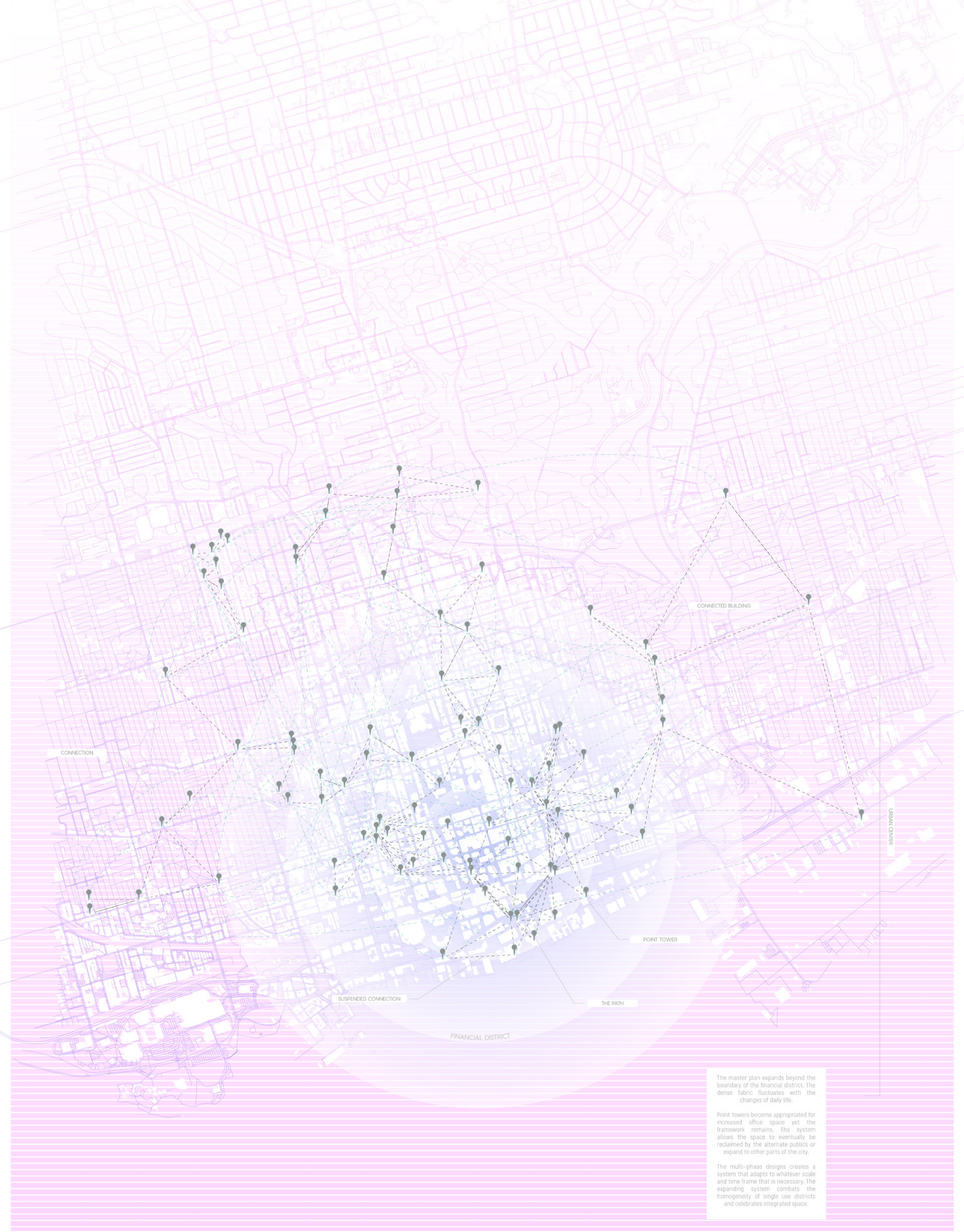

Img 27 | Masterplan

The system begins in the dense financial district and spreads to the rest of the city. As need diminish in one area, they grows in another. The framework that houses uncertainty is not static, it ebbs and flows. 


\section{Phase $1 \quad$ Inhabit}

33 “Greater Toronto Area Office Marketview, Q4 2019." CBRE. Web. Feb 192020

https://www.cbre.ca/en/re-

search-and-reports/local-mar-

ket-reports/toronto-real-es-

tate-market-reports
The first phase of the design is the most temporary and insurgent, it represents a more literal embodiment of the core's transition from Bigness to Uncertain. Due to the changing needs of businesses and the fluctuating leasing market, vacancies are common in the skyscrapers. Floors in the district lie vacant, the owners of the buildings do not make any profit from these vacancies and the community does not benefit them either. According to the CBRE Commercial Real Estate Services, as of the fourth fiscal quarter of $2019,2.8 \%$ of commercial office space in the financial core lies vacant (Down $0.1 \%$ since the third fiscal quarter). Of the $26,652,388 \mathrm{sq}$. ft of office space, 746,266 sq. ft is empty. ${ }^{33}$ The conventional method for office leasing leaves a shell that is customized by the tenants. This shell is comprised of empty floors without finishes, furniture or partitions. The downtimes between leases offers a unique opportunity for informal public occupation of the empty floor. The pop-up adoption of vacant floors takes advantage of the Bigness of the skyscrapers, the large spaces open up the possibility of a vast array of temporary programs. Transient playgrounds and childcare facilities could inhabit a space for the months between leasing contracts. The border between the corporate and community spaces begins to blur. 


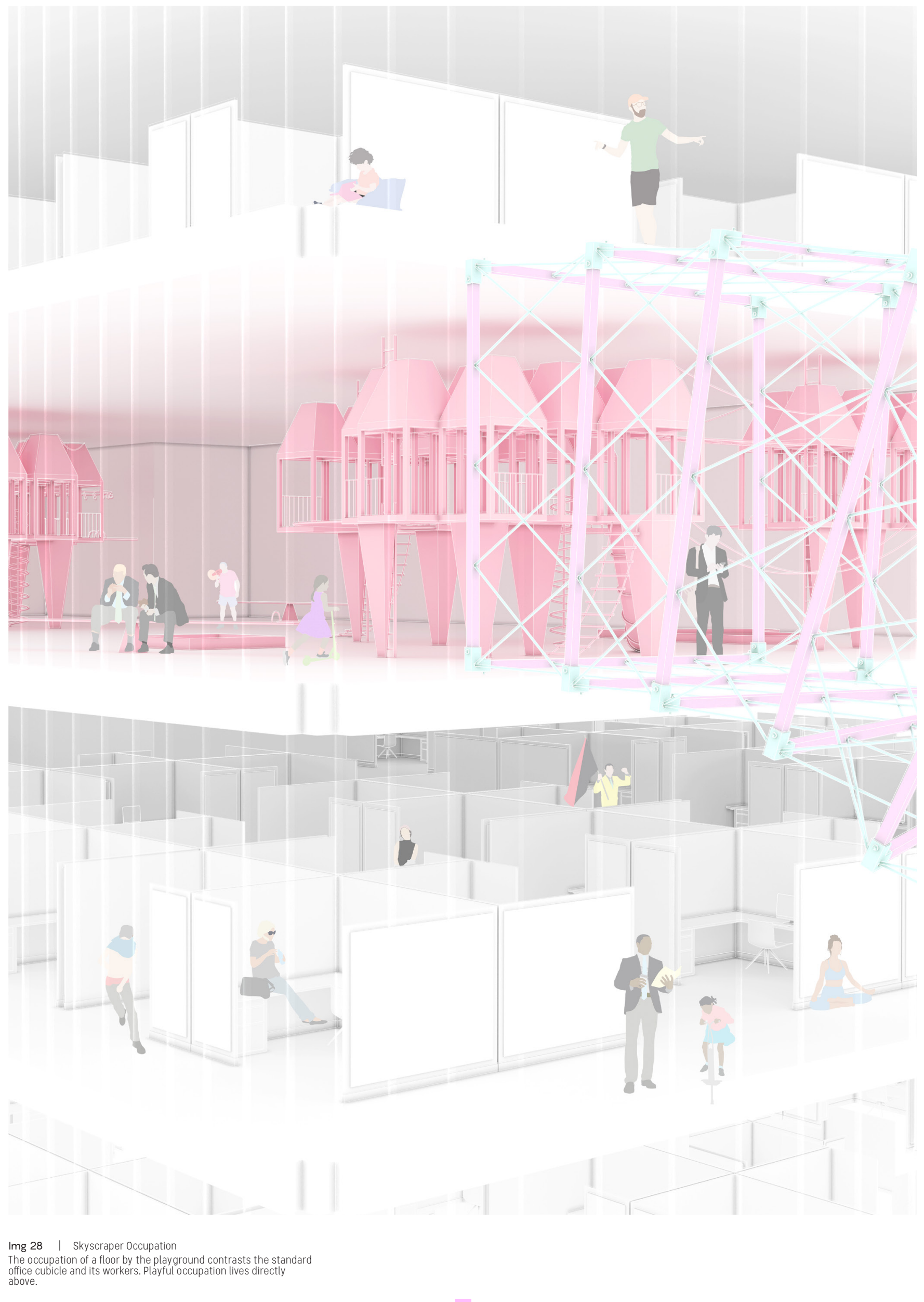

45 


\section{Phase $2 \quad$ Connect}

The second phase addresses two issues of the site: 1. The lack of horizontal circulation. 2. The lack of green space. The proposed green space varies from the traditional public space and the hardscaped parks of the financial district as it creates zones whose sole purpose is that of leisure. This lightweight program removes the need to be doing something productive from the dweller, their occupation of space is its own end. The design of suspended connections examines the vertically divided parcels of the skyscrapers and imagines transient structures that link them together with suspended parks and program. This phase requires co-operation with the existing power structures of the financial district and provides multiple publics with access to these paths. This alternative public access to the network is essential as it mitigates the exclusionary tendencies of other multi-level urbanism. Temporary connections meld the office-worker public with the park-goers and residents of the neighbourhood through the connection of the existing buildings and the new towers. The large structures provide a framework to be clipped-onto, elevators provide vertical access to the elevated system. 


\section{Structure}

The elevated connections work as a temporal system that shifts with the leasing fluctuations of the district and the community. The transient nature of the system requires a demountable, lightweight and simple structure. The elevated armatures are composed of easily disassembled square frames woven together with steel cables to form tensile structures. These tensile armatures clip onto buildings and are supported through the existing construction and connected to the building maintenance units on the roof through a secondary system of steel cables. Deployment of the tensile structures is achieved through portable hydraulic powered collapsible arms that extend the structure to meet an adjacent building where it connects to another armature. The proximity of the skyscrapers works to the advantage of this system as the tensile structures do not need to span long distances. 


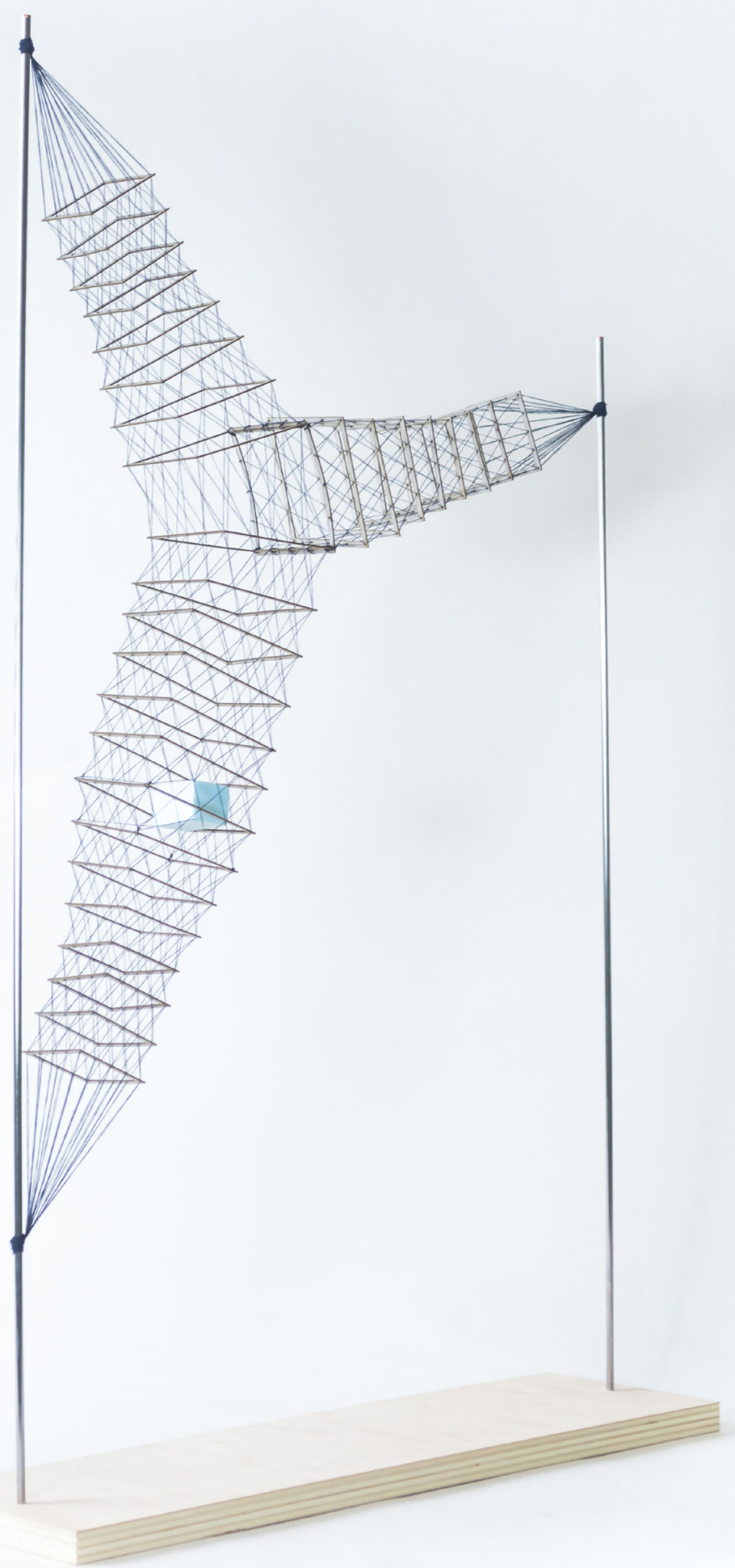

Img 29 | Tensile Model

To assess the structure of the tensile armatures, a physical model was made. 


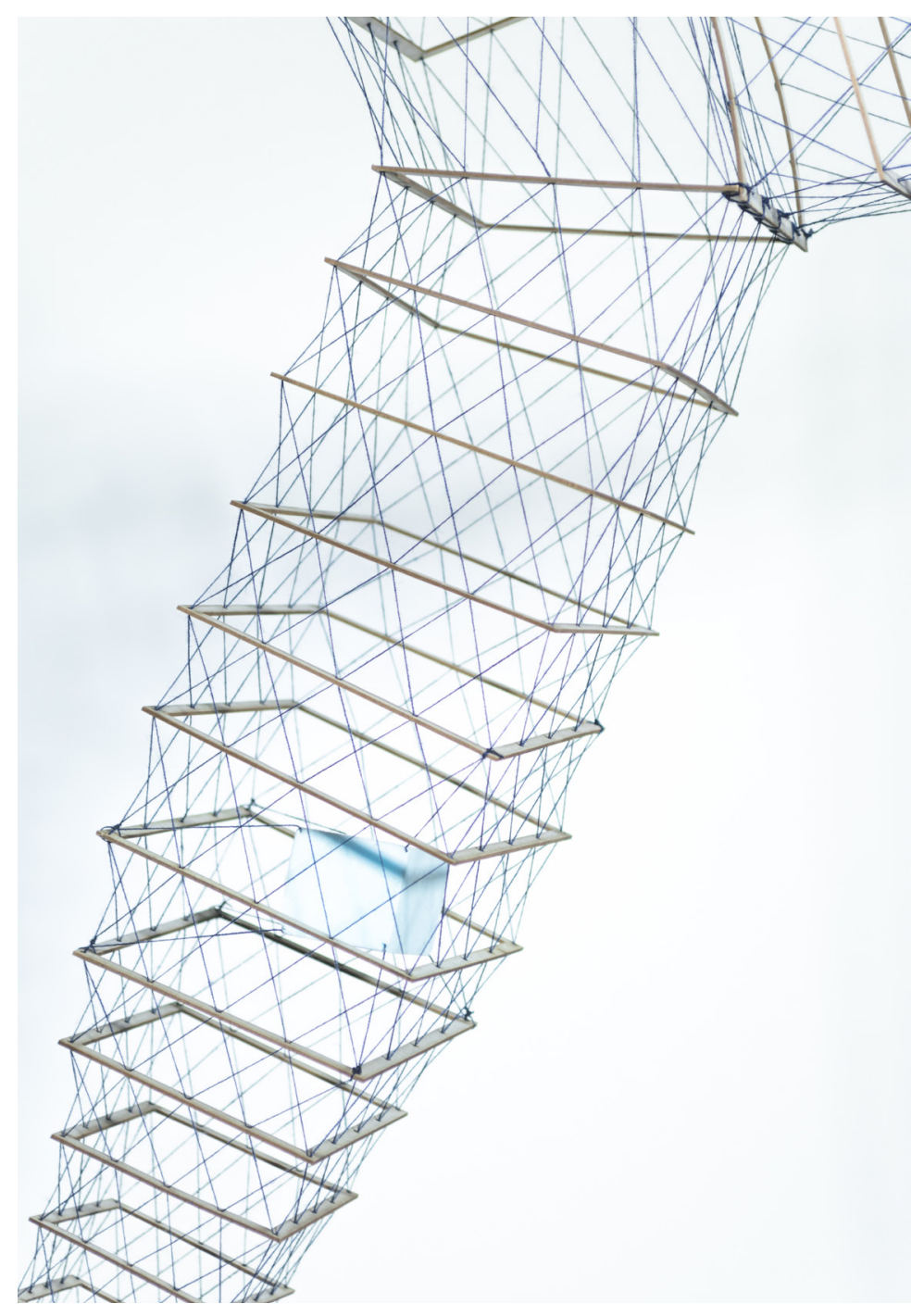

Img 30 | Tensile Model
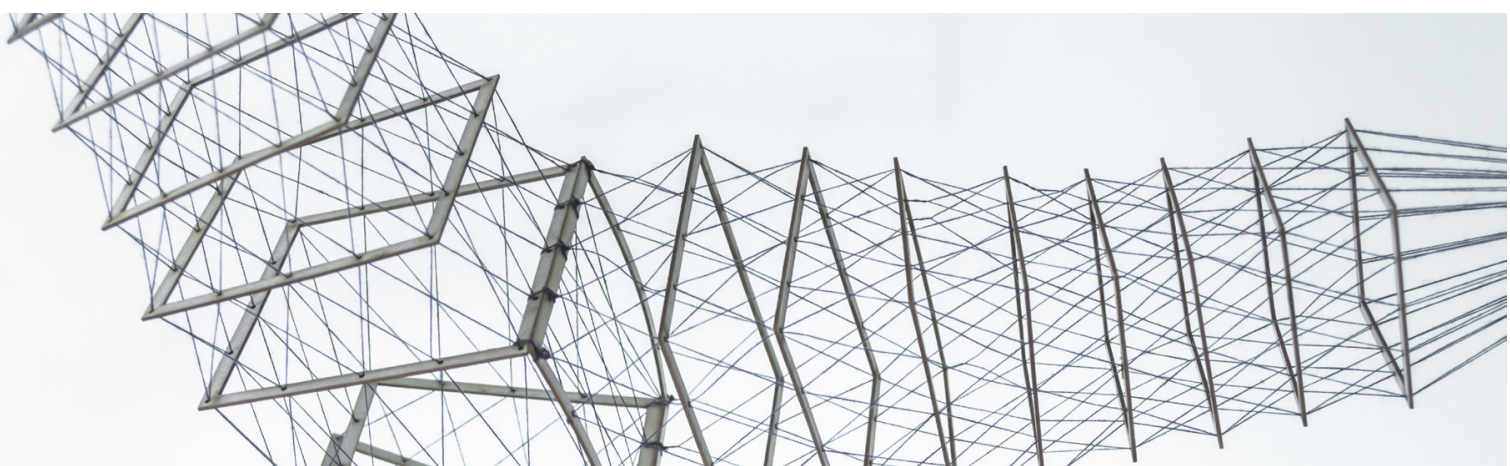
Phase 3

Tower

The site analysis determined a lack of available housing and community services in the vicinity. The new building typology addresses the increasingly vast and complicated needs of a community while remaining in the existing neoliberal system. The scarcity and cost of land in the financial district makes towers the logical proposal for the construction of new buildings. The tower's temporality is important to note as the structure itself is physically solid, but the program and activities within are transitory and integrated. The system the towers exist within is in constant flux due to market forces. A lack in available office space might require the towers to house more space for companies, equally, lack of affordable housing or vacancies in nurseries require the towers' programs to shift in favour of those needs. The intention is that of a system of towers that ebb and flow to create a dynamic urban system.

Embracing the pure size of Bigness, the new tower provides a framework for the uncertain by creating programmatic overlaps and slippages, enhancing vertical connection throughout the building and mixing permanent and temporary occupations. The tower design is created as a prototype to be implemented in different variations throughout the city. The towers' locations allow them to take advantage of The Path, a unique set of underground tunnels. The underground connections enable travels in a large portion of Toronto's downtown core without surfacing. Circulation is found on the original ground plane, above and below. 


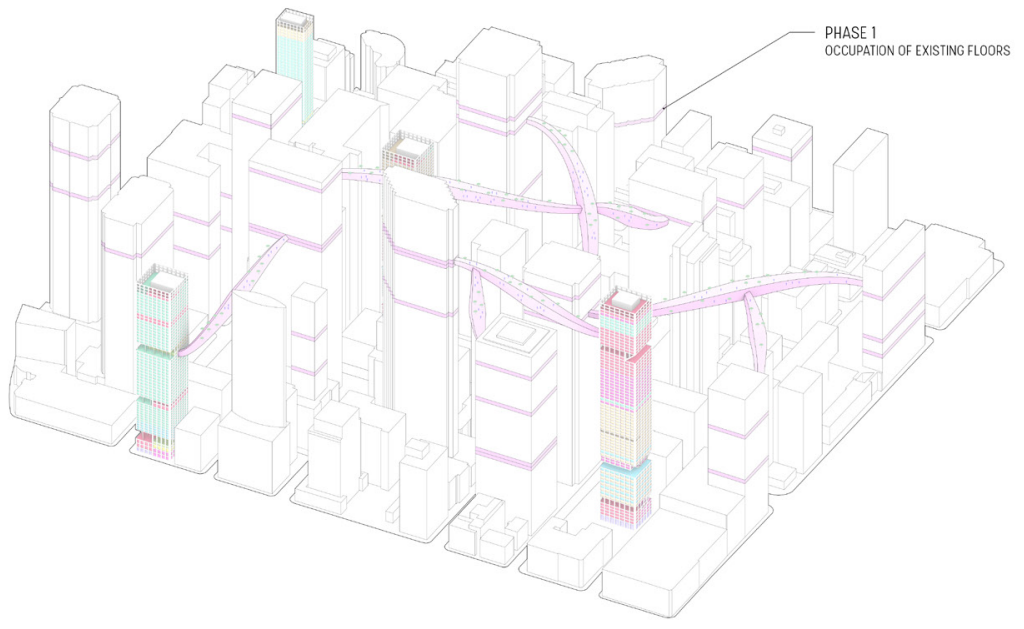

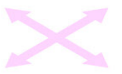

HORIZONTAL CONNECTIONS

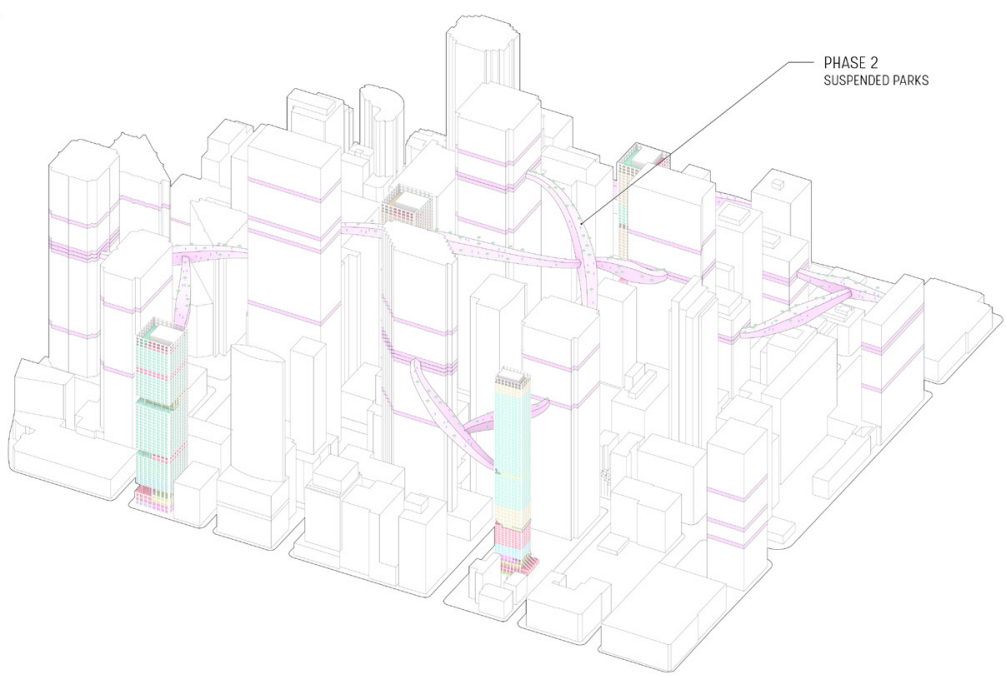

VERTICAL CONNECTIONS

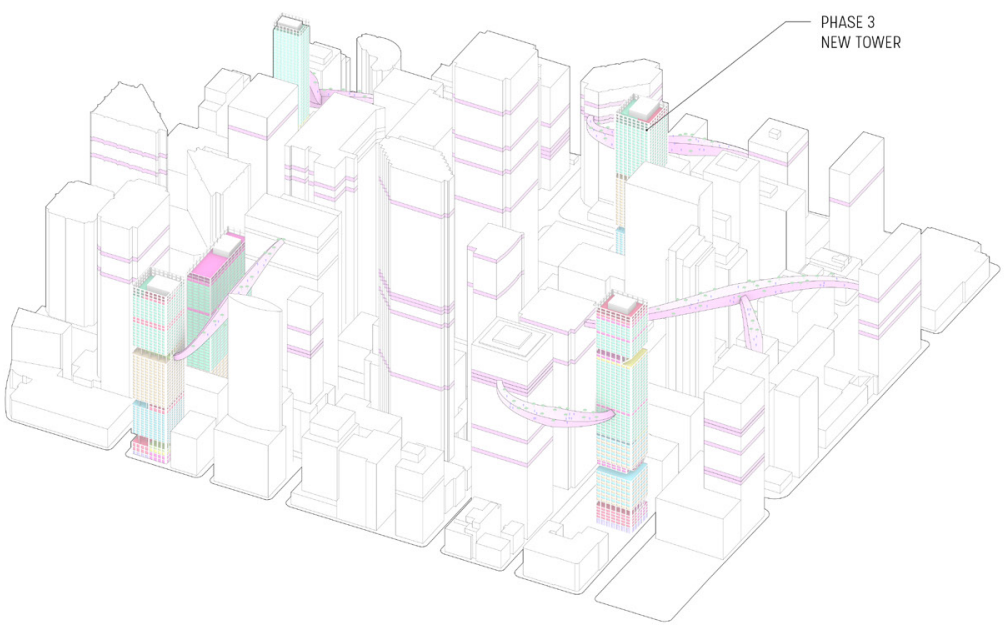

Img 32 | Duration Diagram

This series indicates possible iterations of the three phases. These

phases may occur simultaneously and are transient. The tower 


\section{Program}

The links created by the tensile structures produces a series of connected parks. These parks are complimented by the possibility of programs to be sprinkled throughout the system. The programs in the elevated greenspaces must remain light and temporary to not interfere and clutter the space. The light programming will consist of moments of repose for adults and play areas for children in the outdoor leisure spaces. The elevated parks will be populated with: Playgrounds, seating and lounging options, alcoves for privacy and repose. The elevated green spaces provide moments of calm in an otherwise busy city center.

\section{Office}

The office floor is no longer confined to a single horizontal parcel, vertical openings, volumes, and community spaces are woven throughout the floors. The multi-story openings provide those leasing the space with connections to the varying publics and visual connections to the rest of the city.

\section{Market Rate Housing}

Living space is integrated into the neighbourhood. The isolation of traditional condominiums is mitigated by the sharing of facilities, elevators and public space with those in the affordable housing units. 


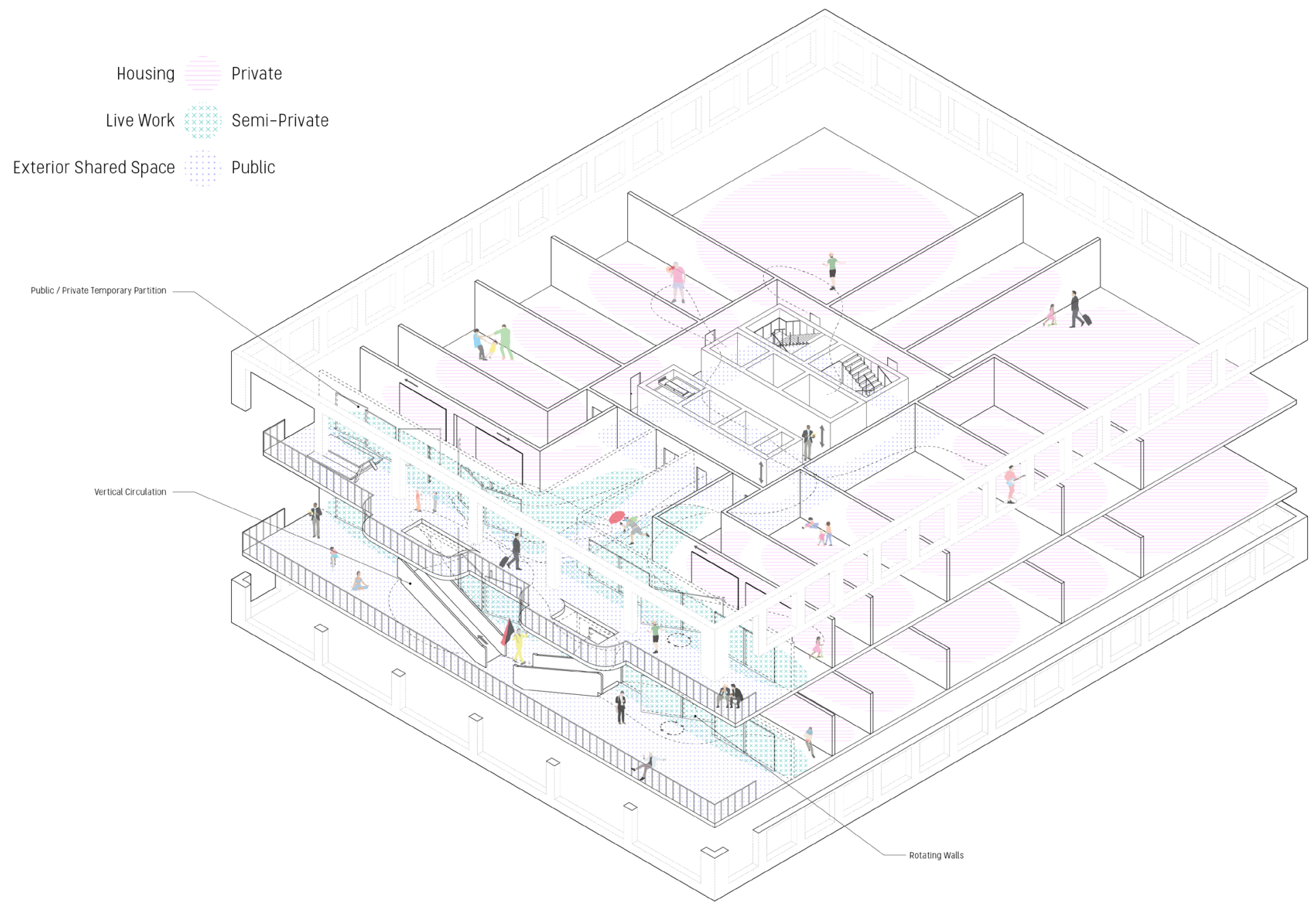

Img 33 | Housing Community

Exterior space is shared on the housing floors. The housing program omits the private balcony

in favour of communal outdoor space for public interaction. Floors are pulled away from the

building 's racade to create this double height exterior space that melds the public and private. 


\section{Social Housing}

34 Statistics Canada. 2017

5350014.00 [Census tract], Ontario

and Toronto [Census metropolitan

area], Ontario (table). Census Pro-

file. 2016 Census. Statistics Canada

Catalogue no. 98-316-X2016001.

Ottawa. Released November 29.

2017.

https://www12.statcan.gc.ca/

census-recensement/2016/

$\mathrm{dp}-\mathrm{pd}$ /prof/index.cfm? Lang=E

(accessed January 18, 2020).
Housing in the neighbourhood will not be limited to those who can afford downtown Toronto's high prices, $13.1 \%$ of the inhabitants of the district are considered low-income, ${ }^{34}$ the introduction of affordable housing allows those working jobs with lower salaries to live in closer proximity to their work, reducing long commute times.

\section{Community}

The community centre program is the most variable as it contains several smaller types of public occupation under its umbrella. While it provides gathering spaces for the community as a whole it also encompasses all the community outdoor and physical activity spaces. These programs are possible within the framework provided by the tower, but they are not permanent or existing in every iteration of the tower. The buildings themselves provide space for such programs as there is no prescriptive formula for every site.

\section{Circulation / Connection}

The vertical circulation spaces in the towers a composed of a series of openings with the means to create linkages between floors. Ramps, staircases, tertiary elevators etc. These transient spaces are unprogrammed and are to be utilised by those in current need of the space. These areas provide stages for unforeseen overlaps by remaining open and being integrated throughout the buildings. 
35 Scrinko, Jordon. "How Much Does It Cost to Build a Condo in Toronto in 2020?" Precondo, Precondo, 24 Feb. 2020, precondo. $\mathrm{ca} /$ how-much-does-it-cost-tobuild-a-condo.

36 "Canadian Cost Guide 2019 - Our Commercial Real Estate Services: Altus Group.” Our Commercial Real Estate Services Altus Group, www. altusgroup.com/services/reports/ canadian-cost-guide-2019/.

37 lbid.

38 Cramdown, Ralph, et al. “What Does It Cost To Construct A Condo In 2018?" Toronto Realty Blog. 19

Mar. 2018, torontorealtyblog.com/

blog/cost-construct-condo-2018/

\section{Building}

The system of towers is providing alternate forms of inhabitation that do not follow traditional building developments in Toronto, but they must adhere to the existing financing models to be constructed. Developer profit margins in downtown Toronto vary from $\% 12$ - \%20,35 developing a new type of tower while still profitable will reduce these margins. The more profitable programs of the market rate housing, leasable office space, and underground parking aim to fund the public and community-oriented programs.

\section{Construction}

The construction of the towers is dependent on three types of cost: Land Cost, Construction Costs, and Soft Costs. Land costs in downtown Toronto are among the highest in Canada (Second only to Vancouver) roughly \$200 - \$250 per square foot. ${ }^{36}$ The construction cost vary slightly depending on the use, the calculations were done while incorporating multiple uses. Residential: \$280 sqft. - 0ffice: \$340 sqft. - Parking: \$150 sqft. - Schools: \$180 - \$265 sqft. - Supermarket: \$215 sqft. - Recreational: \$225 - \$330 sqft. - Library: \$290 - \$440 sqft. - Aquatic Facilities: \$385 - 490 sqft. ${ }^{37}$ The soft costs associated with the construction are the marketing, contractors, city development fees and other adjacent costs, they augment the costs by roughly $\$ 150$ sqft. $^{38}$ Costs were estimated for the 60 story prototype point tower: Land costs $\$ 3$ million, hard costs : \$180 million, soft costs : $\$ 9$ million. With 30 office floors and 10 market rate floors for financing, the remaining 20 floors for affordable housing and community amenities were able to be constructed with an $8 \%$ profit margin. 


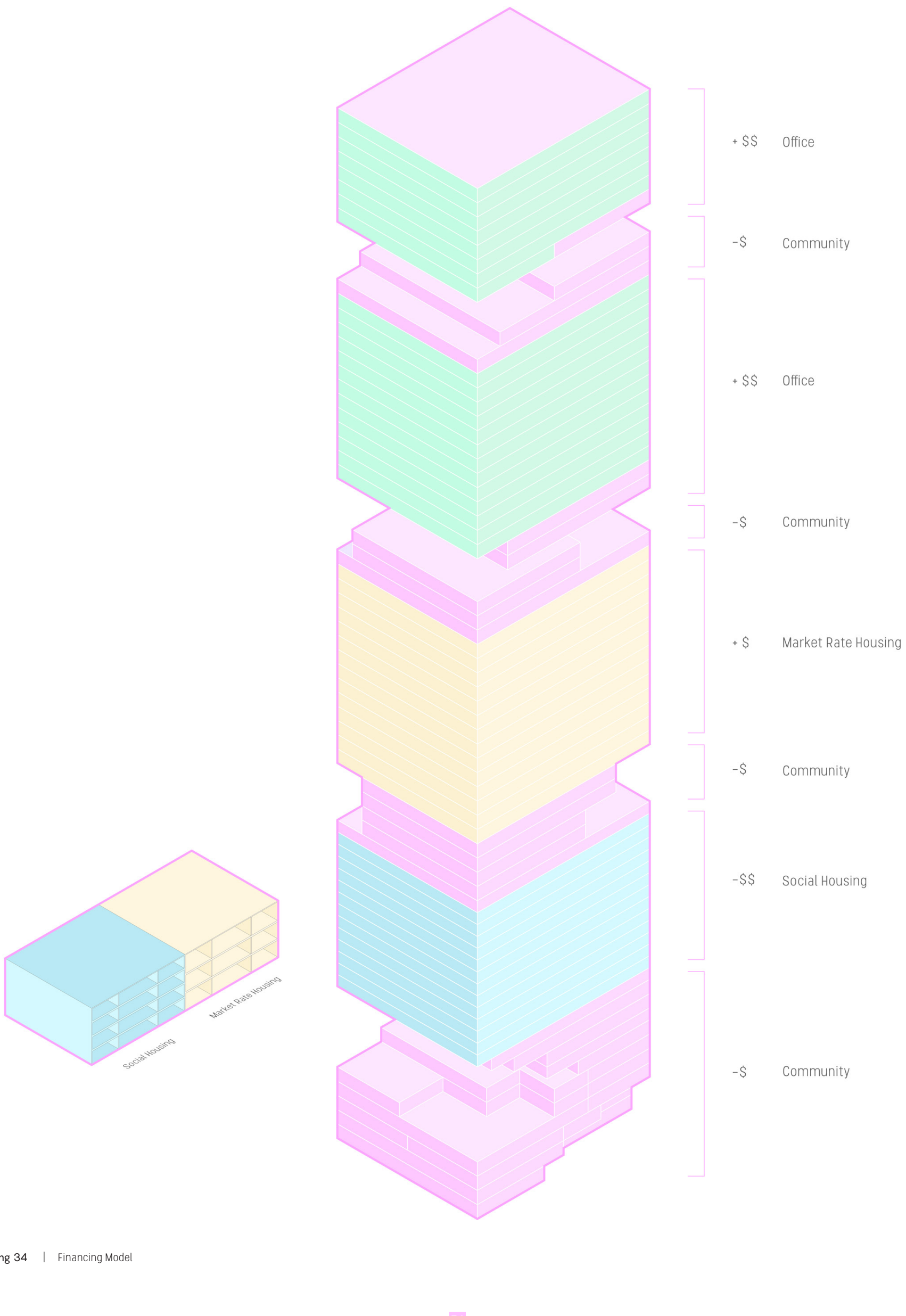




\section{Design}

The design of the towers is intended to exist within the context of the neighbourhood while allowing for the programmatic hybridizations to occur on the interior. The instability of the towers is rendered through the carving out of space on the interior masked by the grid façade. Floorplates are pulled away from the exterior of the towers to reveals moments of communal space. The subtractions and vertical connections enable light to enter the exterior spaces in the towers and remove the rigidities of the virgin site seen in most existing skyscrapers. The cutaways from the interior of the building provide essential outdoor space: a basketball court on the 59th floor would be much more enjoyable with access to outdoor air, the roof top skatepark is a fun activity for the disenfranchised office-worker, the 37th floor playground provides a distraction for the kids living in the buildings so their parents can have a rest. The design of spaces and temporality of programs within the towers lends themselves to encompass the lives of the transient publics that inhabit them 


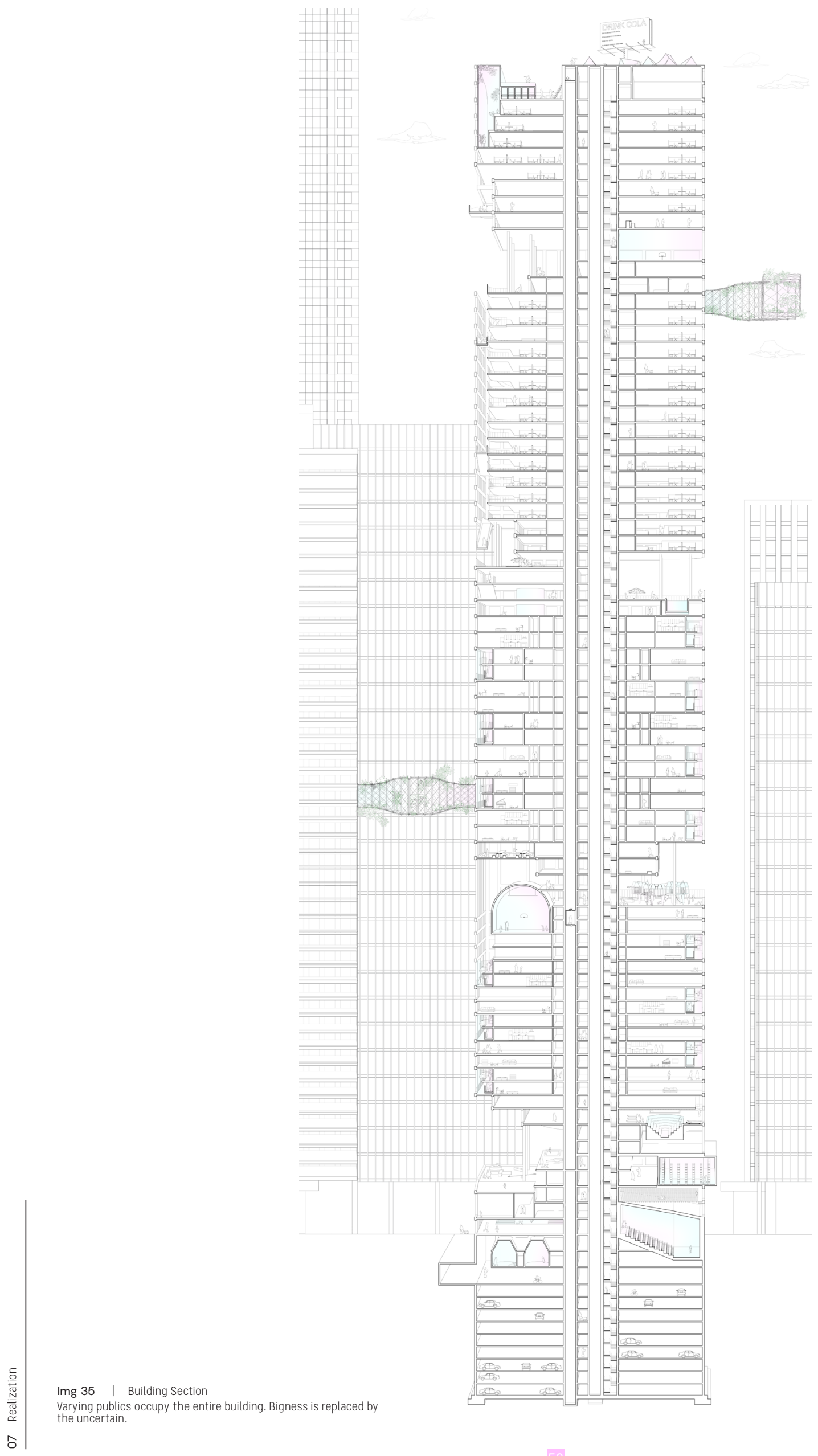




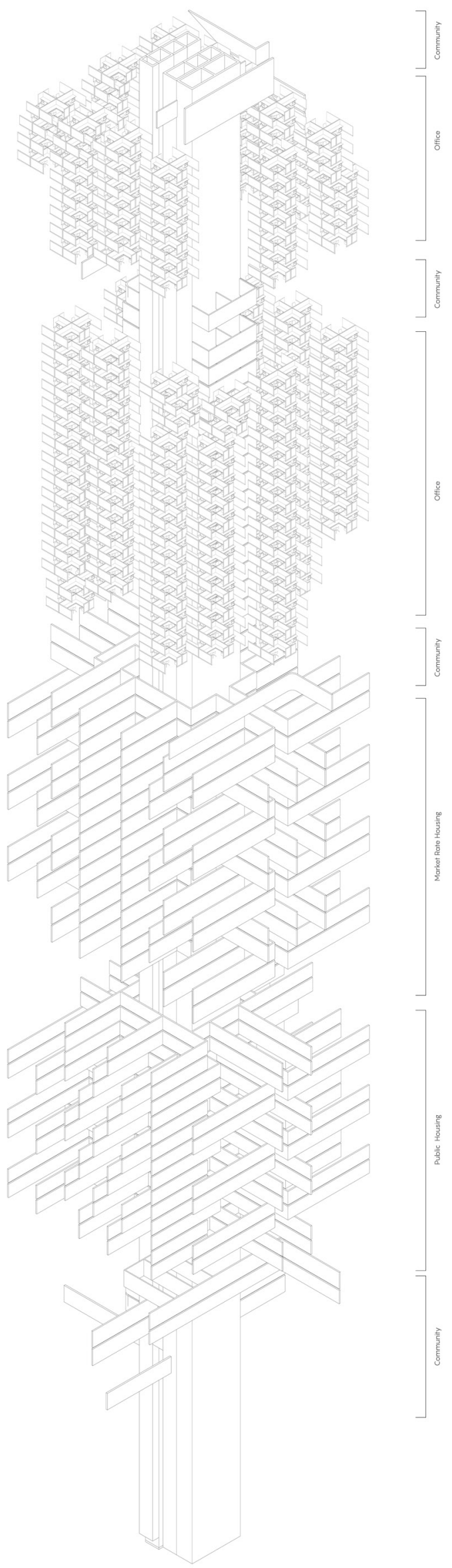

Img 36 | Private Program

Private spaces for business and living are no longer disconnected from the community. 

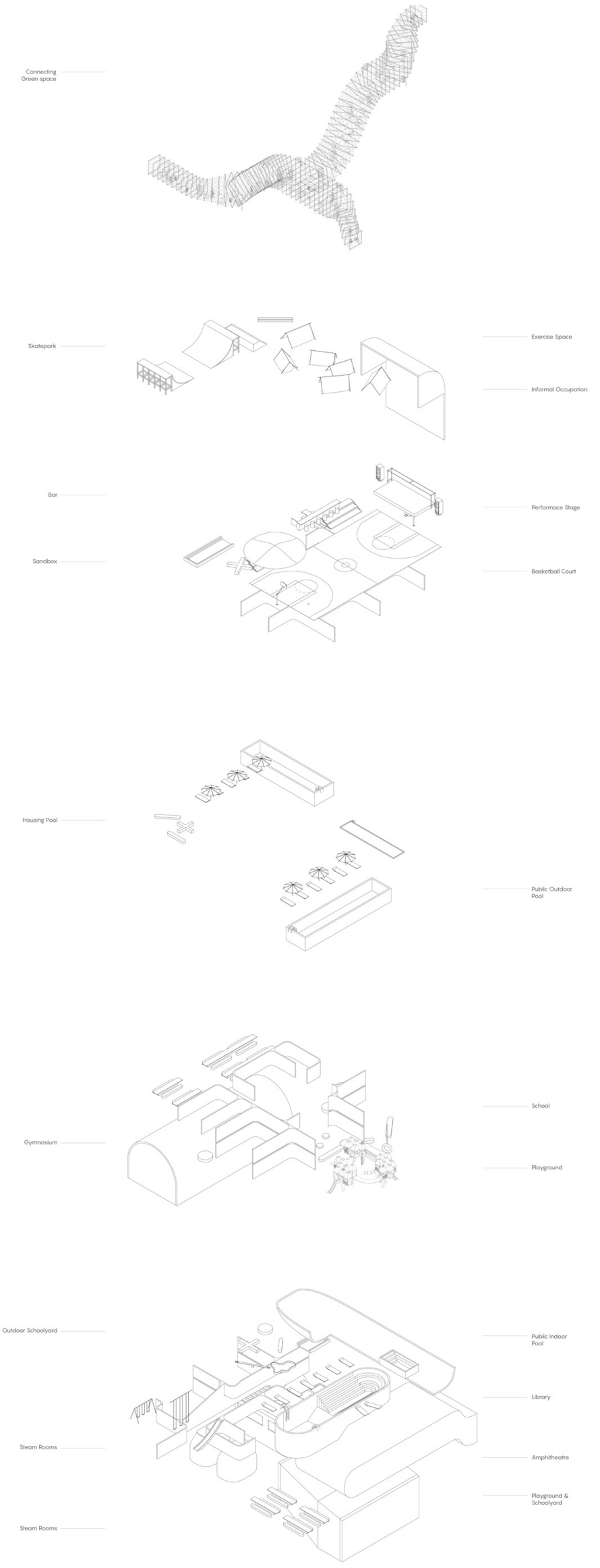

Img 37 | Community

Shared community spaces are sprinkled throughout the towers. 


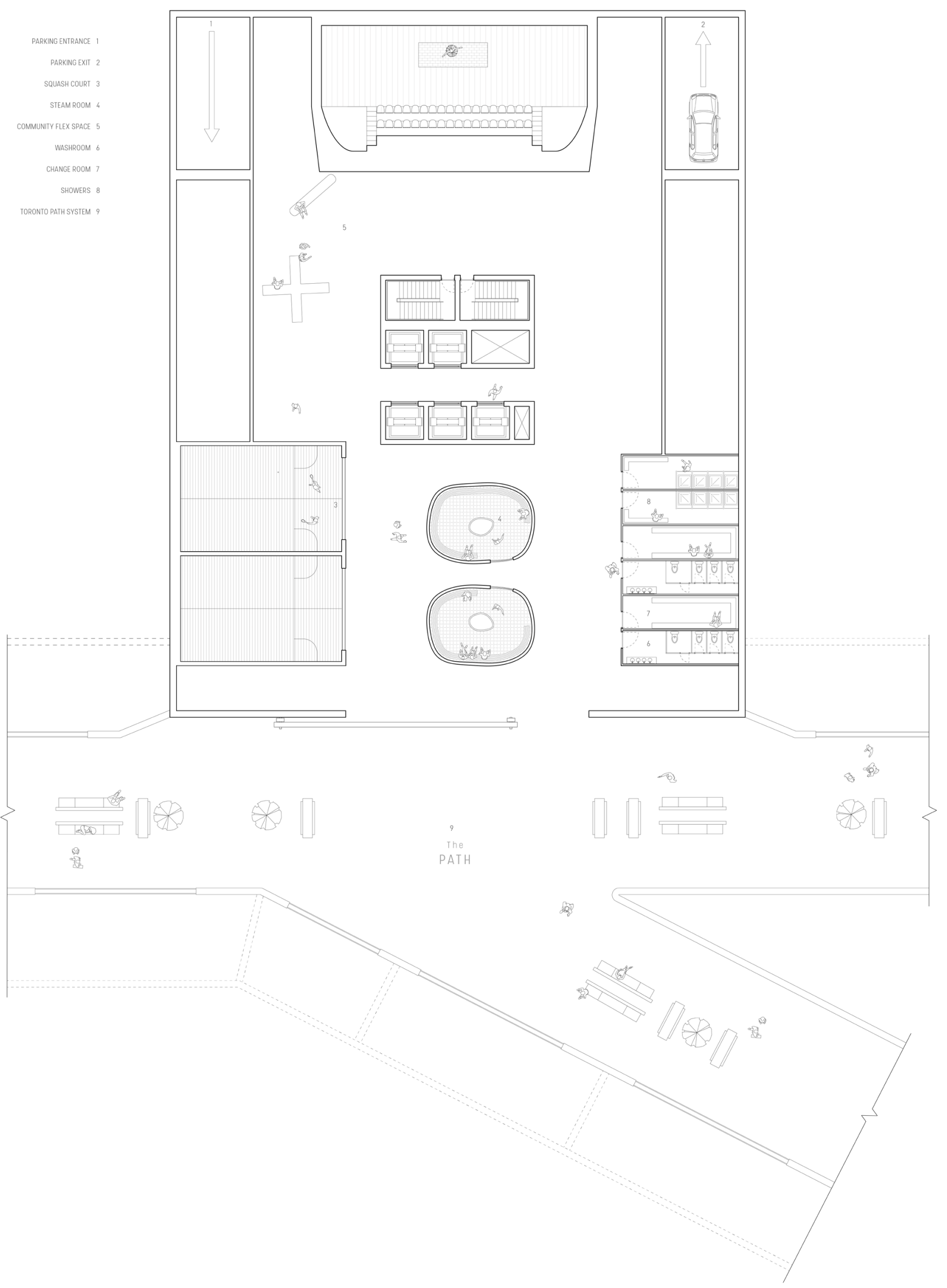

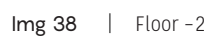




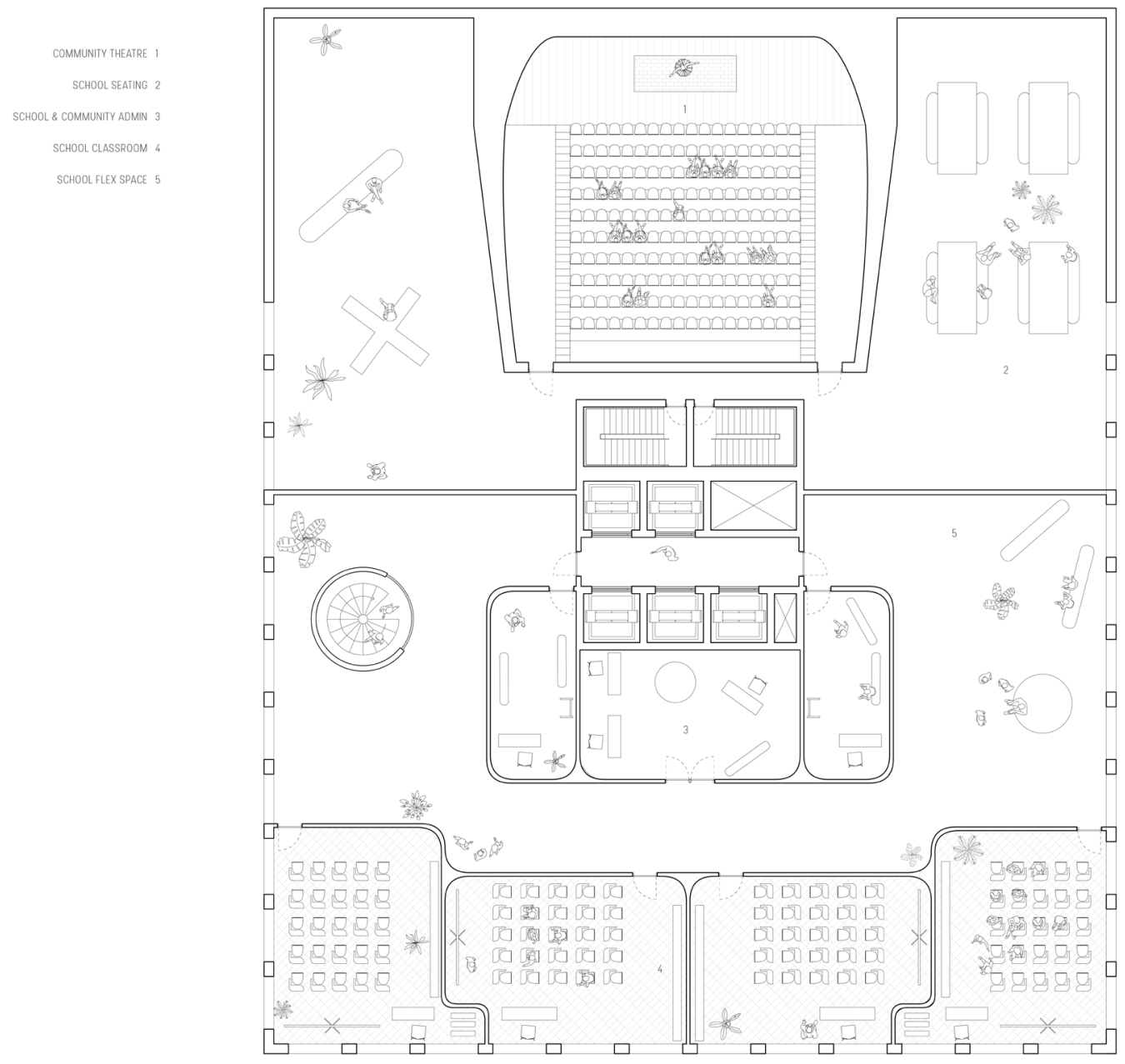

\begin{tabular}{l|l} 
Img $39 \quad$ Floor 2 &
\end{tabular} 


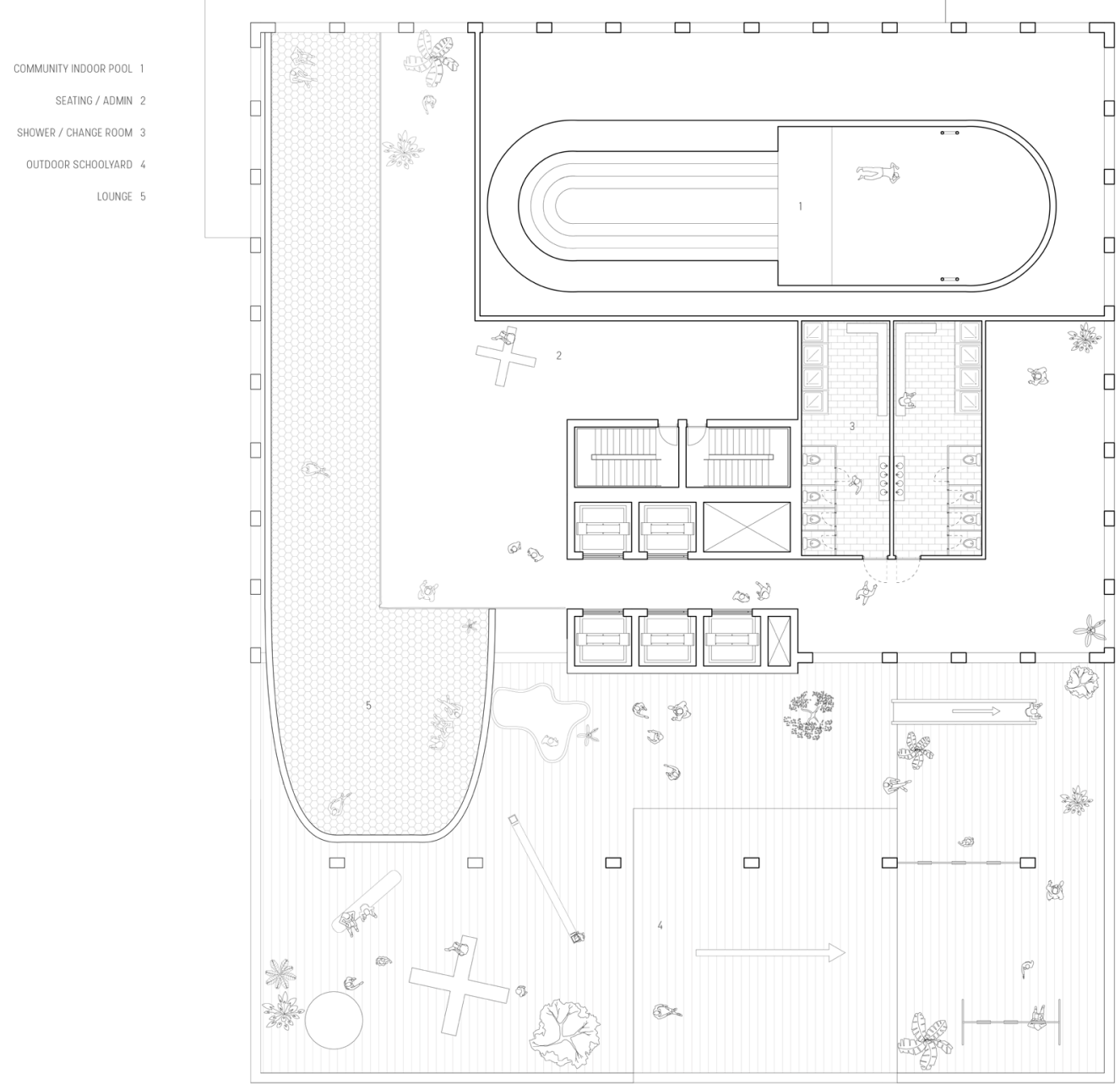

\begin{tabular}{l|l} 
Img $40 \quad$ Floor 7
\end{tabular} 
| SOCIAL HOUSING OUTDOOR POOL , COMMUNIIY OUTDOOR POOL 2

$$
\text { RAMP } 3
$$

GREENHOUSE 4

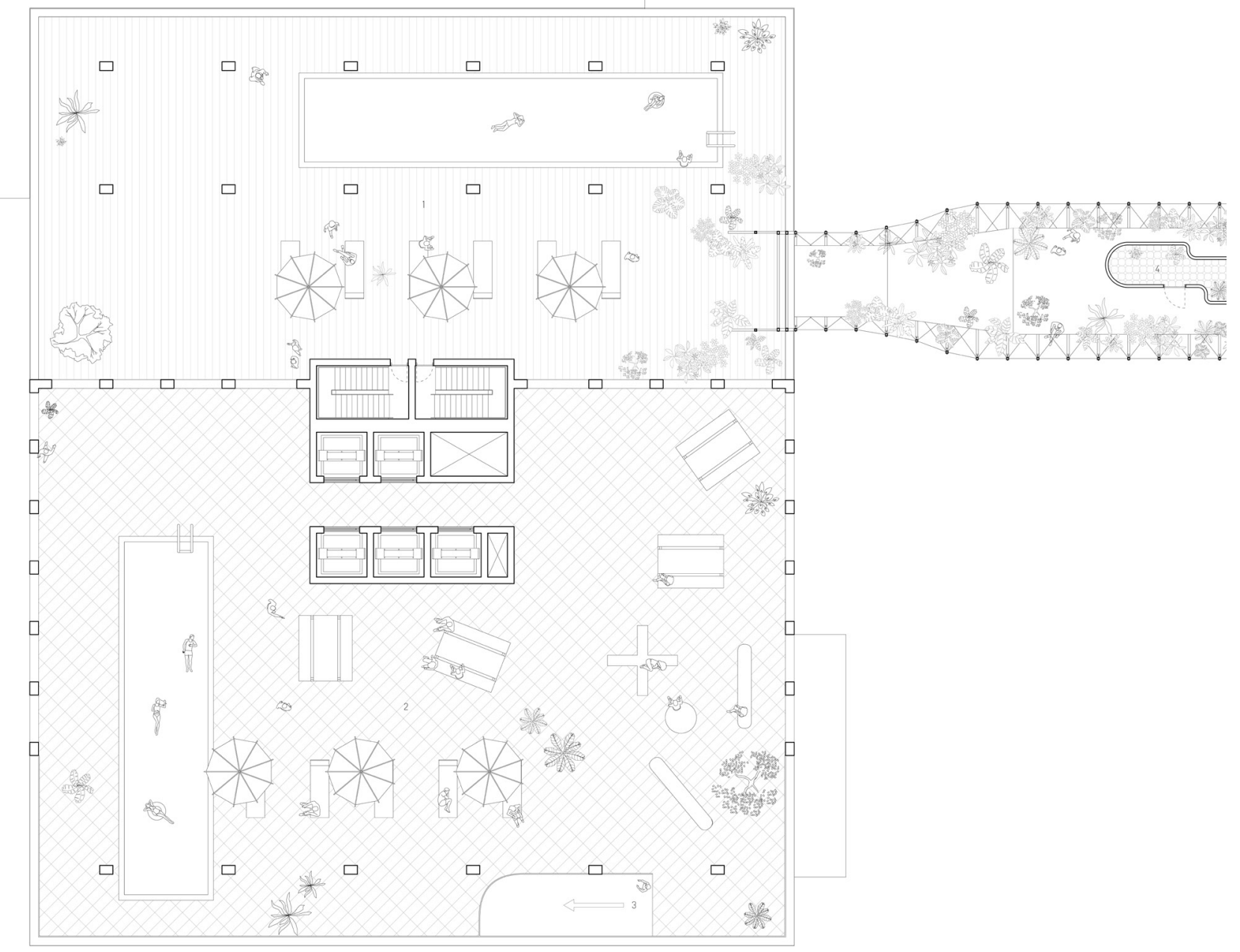

$\operatorname{lmg} 41$ | Floor 44 
BASKetBall COURT ।

COMMUNIIY OUTDOOR SPACE 2 OFFICE / COMMUNITY ATRUM 3 RAMP 4

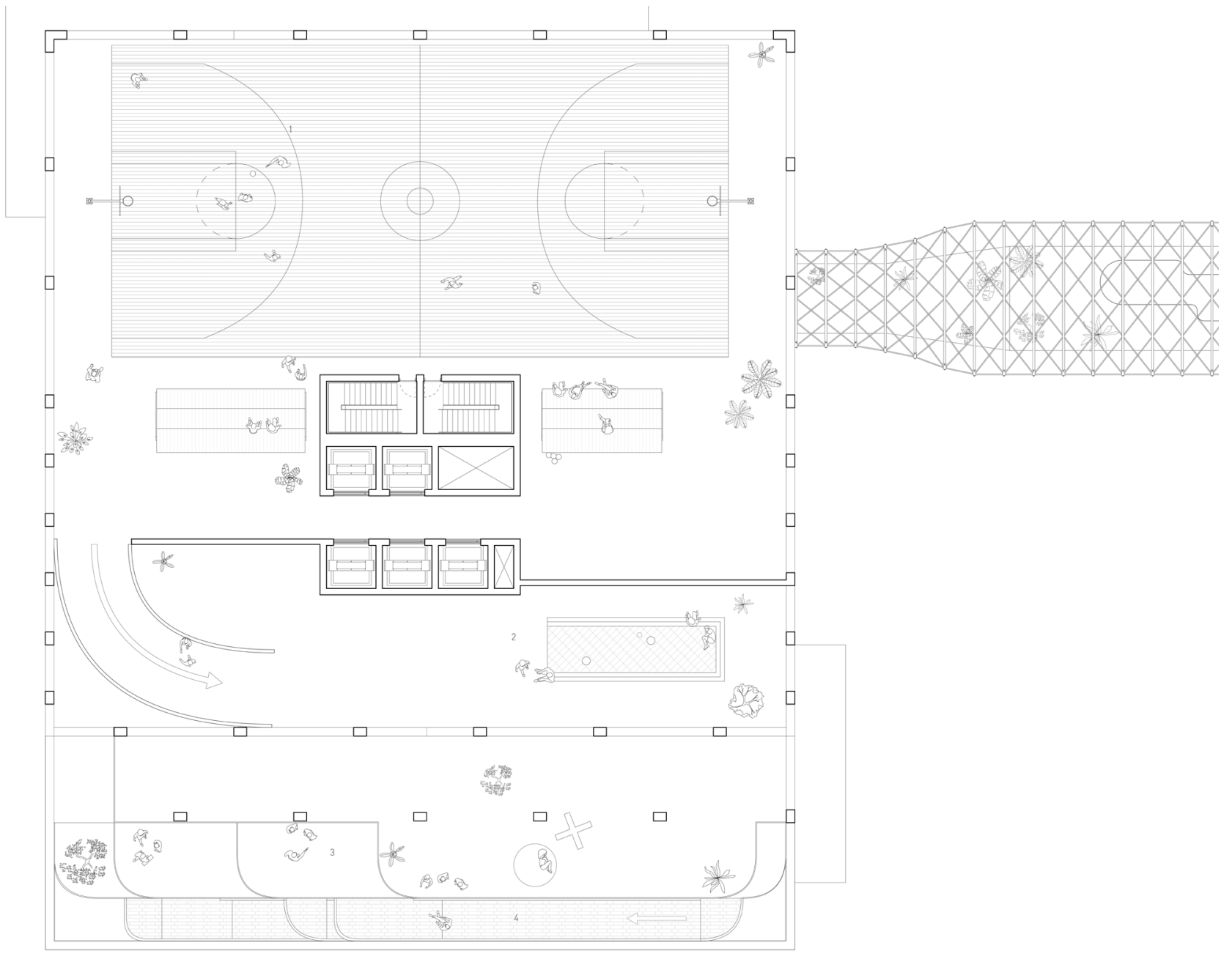

Img 42 | Floor 63 


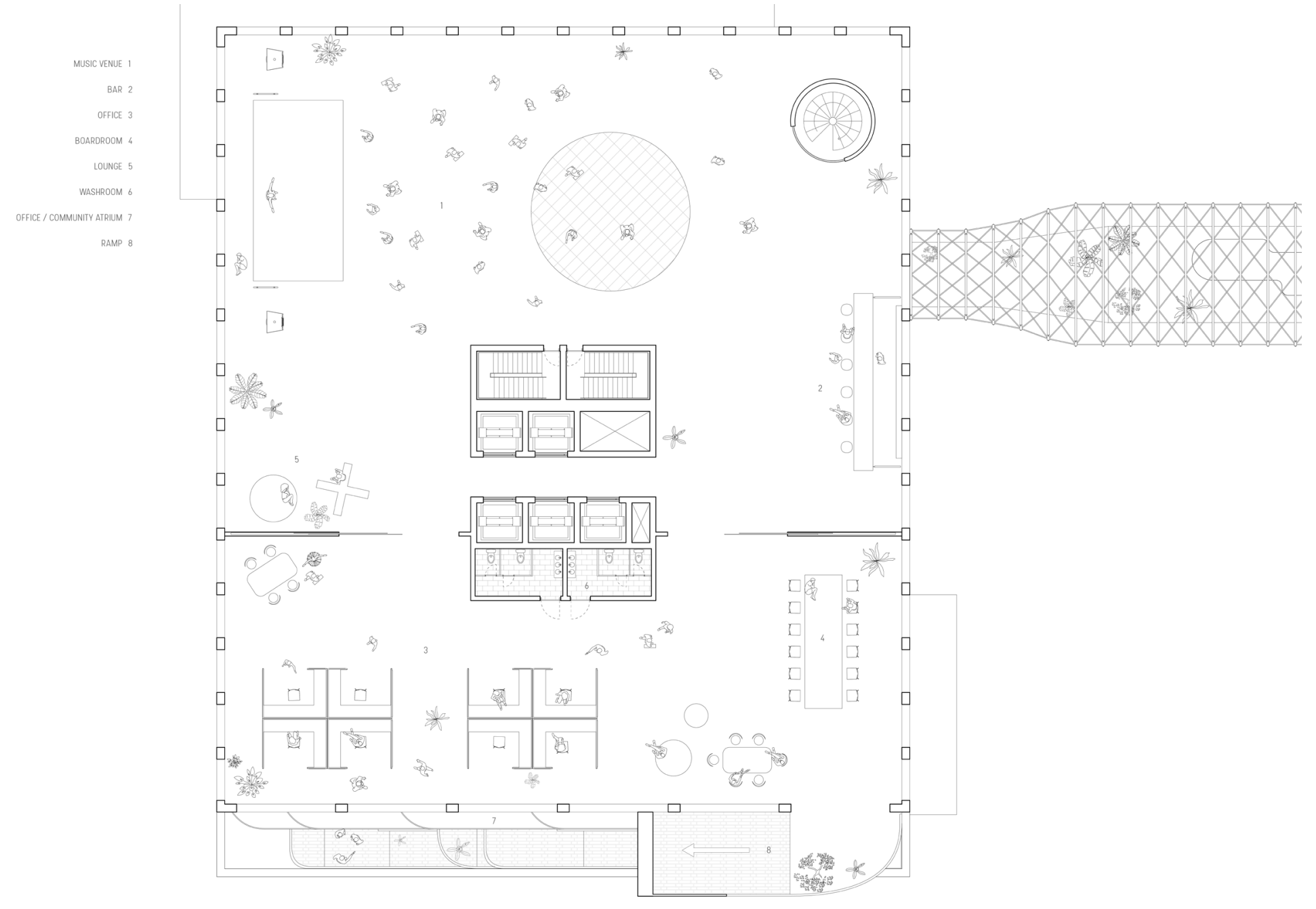

Img 43 | Floor 64 


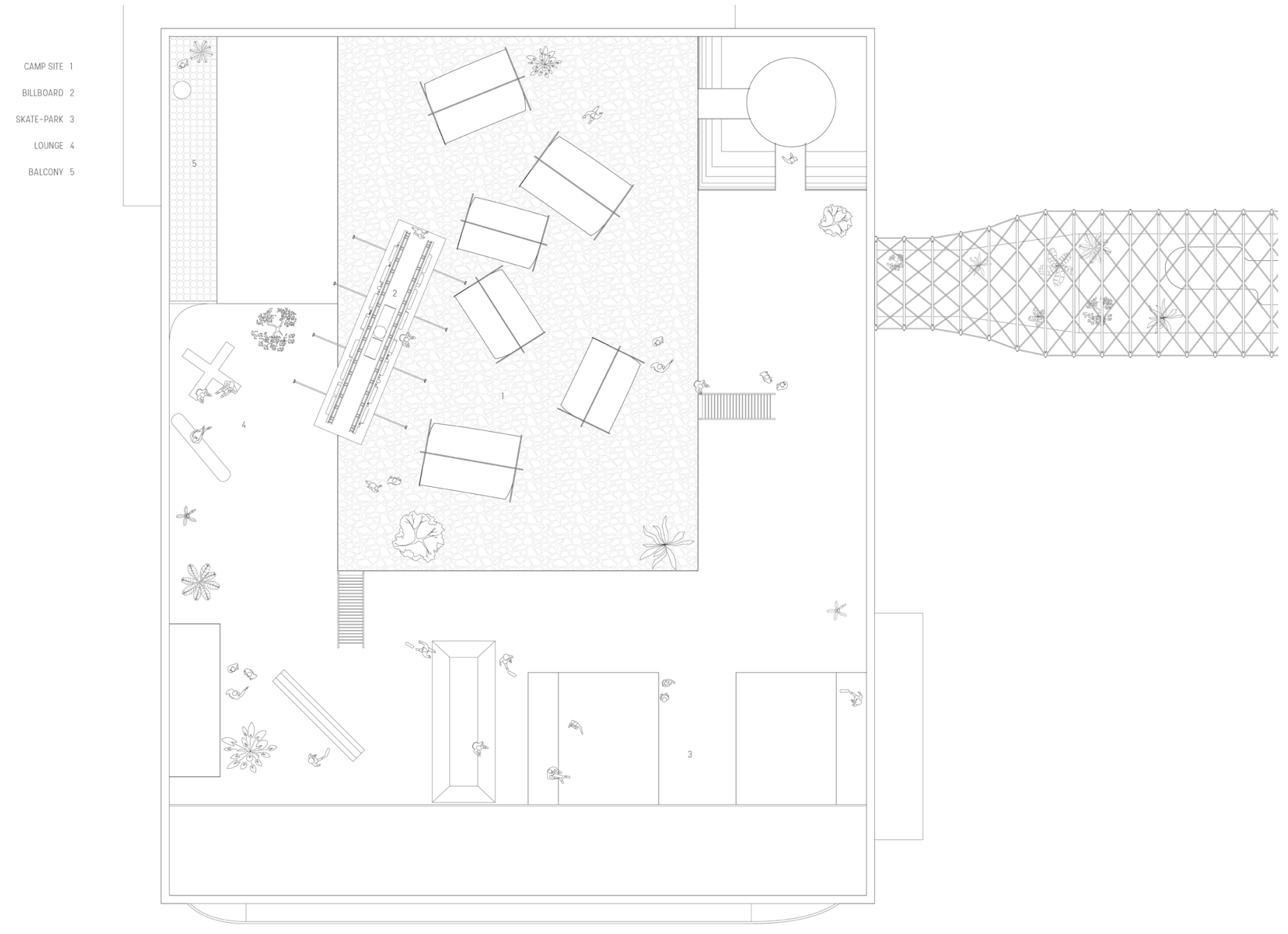

Img 44 | Floor 73 (Roof) 


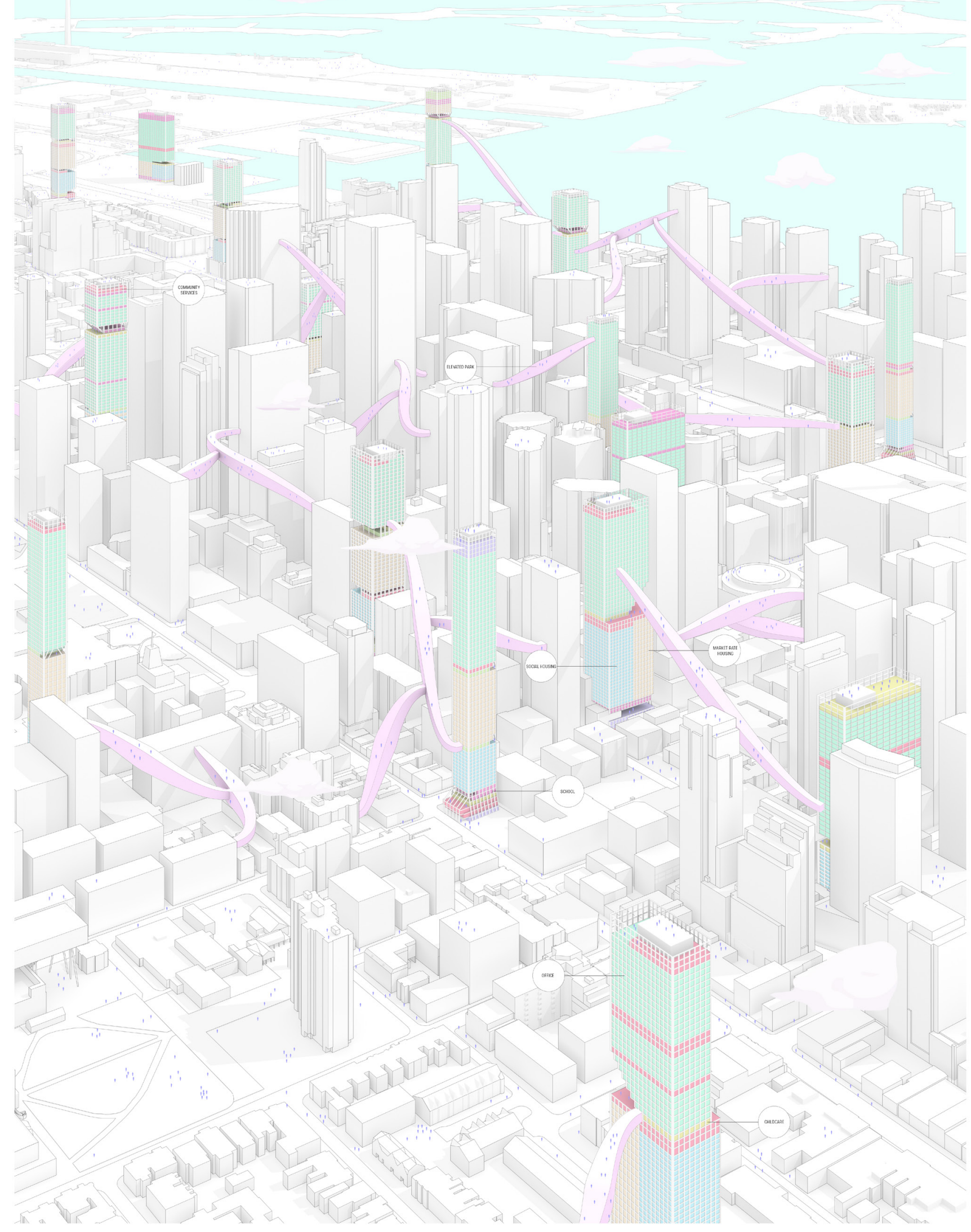

Img 45 | Conceptual Diagram

The system of floor occupations, armatures and towers propagated throughout the city. 


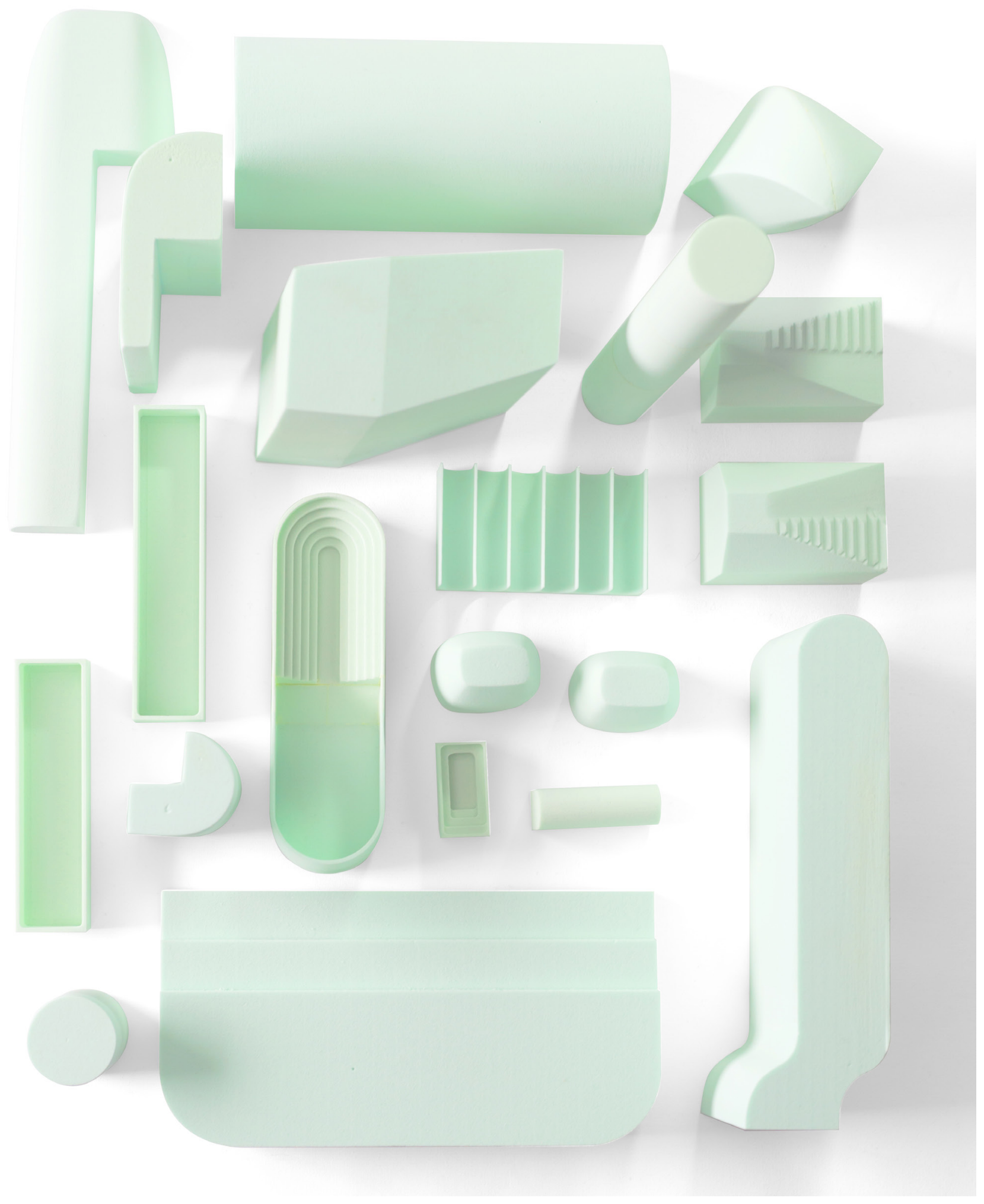

Img 46 | Public Program Voids

The voids in the building were digitally fabricated with a CNC router

in high density foam. Each piece represents a different public

program. 


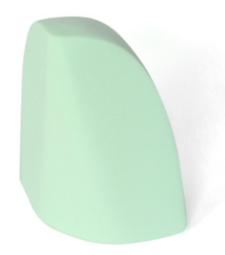

OFFICE OUTDOOR SPACE

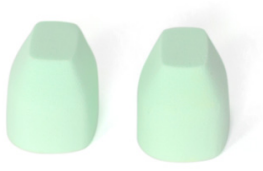

STEAM ROOMS

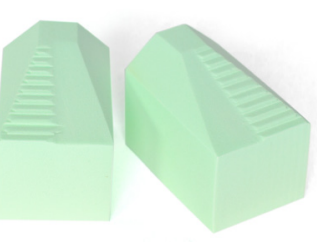

SQUASH COURTS

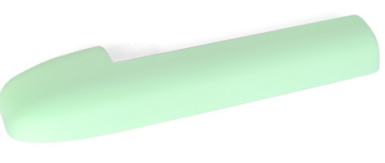

LOUNGE

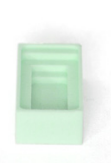

HOT TUB

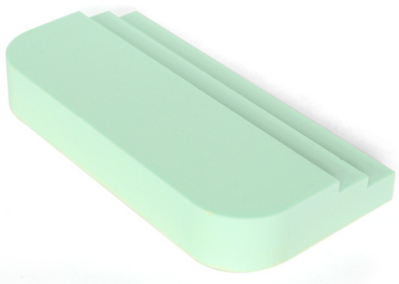

ATRIUM

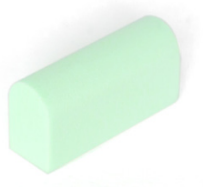

COVERED VERTICAL CIRCULATION

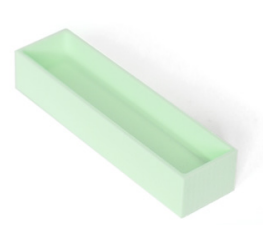

HOUSING POOL

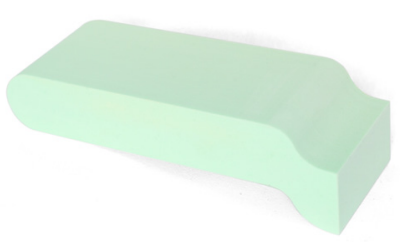

LBRARY

SPIRAL STAIR

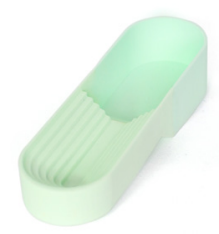

COMMUNITY POOL

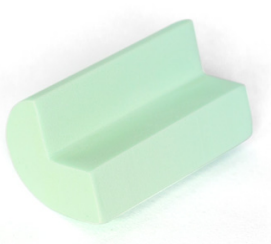

EATING SPACE

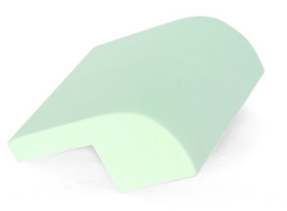

SPORT FACLLITY

THEATRE

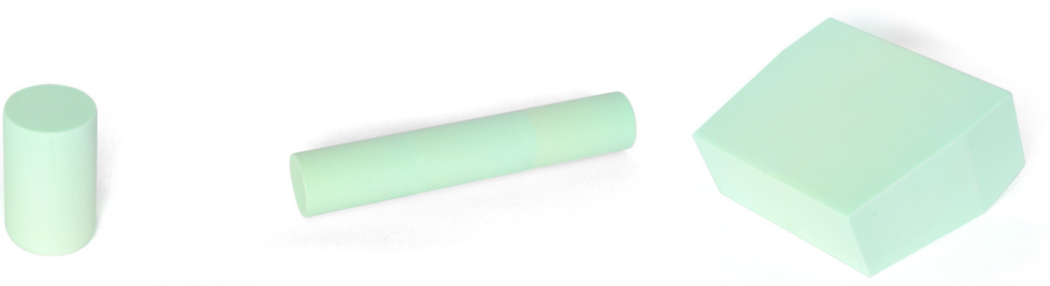

SPIRAL STAIR

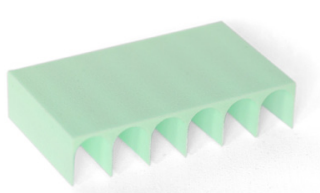

Img 47 | Program Classification

The solids created from the voids carved out of the building are

categorized to identify their use. 


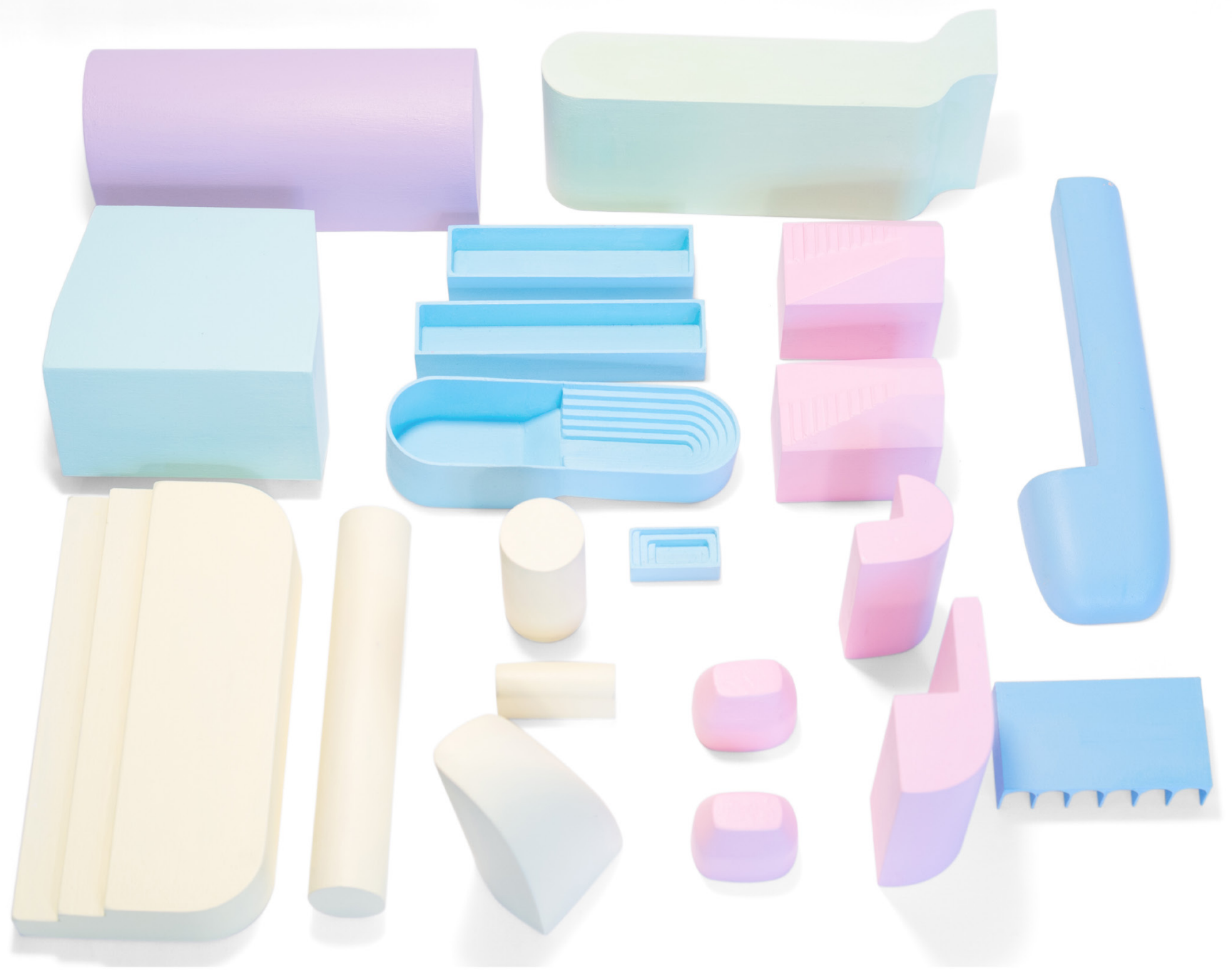

Img 48 | Program Codification

The community programs are divided into their uses by colour. 


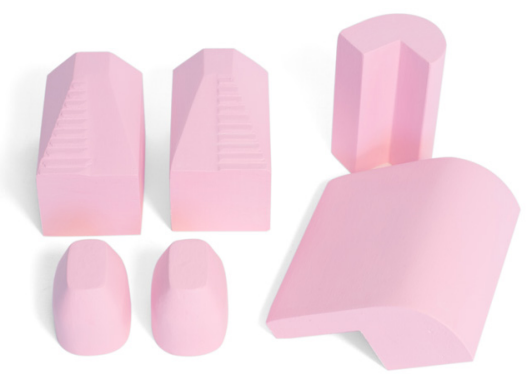

Exercise and recreation

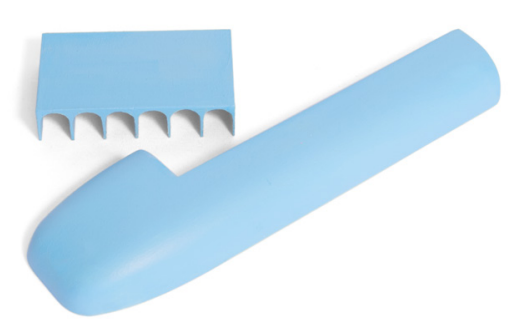

Lounging

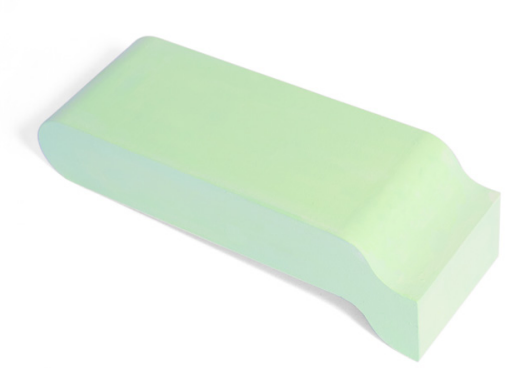

Library

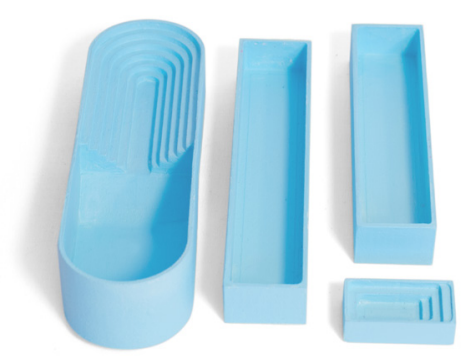

Swimming

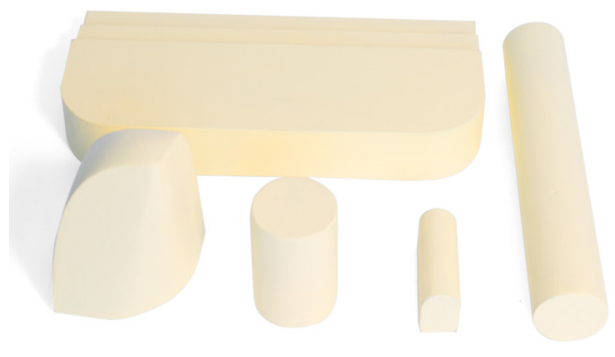

Vertical Circulation

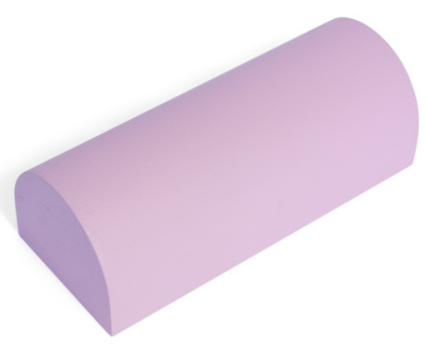

School Gymnaisum

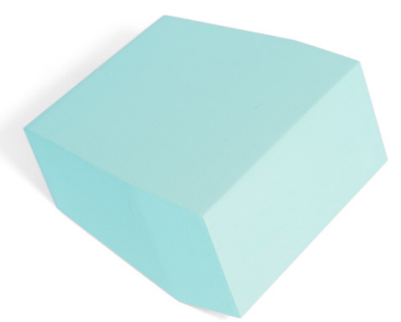

Theatre 


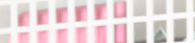

in

IIIIII)

IIII)

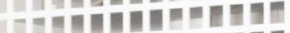

แับ

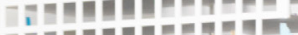

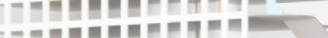

-

गा

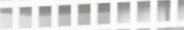

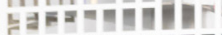

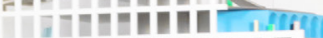

417

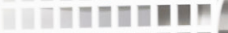

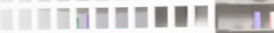

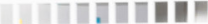

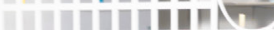

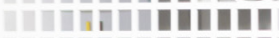

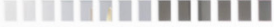

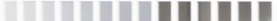

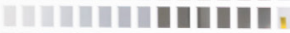

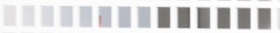

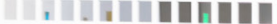

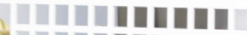

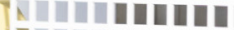

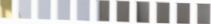

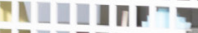

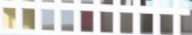

10000

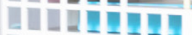

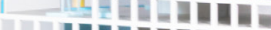

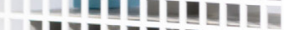

10101ำำำ

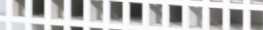

1-1910

4a10107087

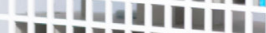

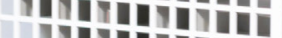

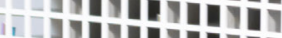

117878

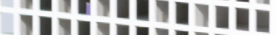

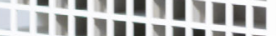

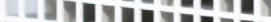

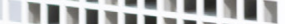

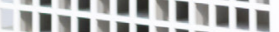

mingiver

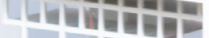

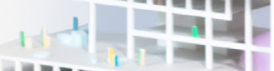

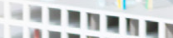

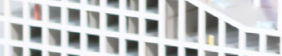

1978

4ำing

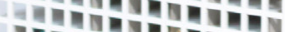

งทำ

งทำ

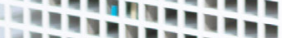

ง

งกำ

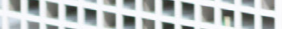

ง ำ

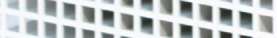

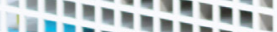

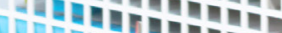

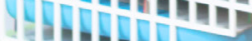

1974

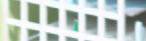

uำ

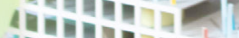

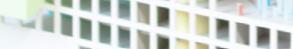

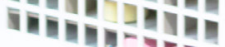

Img 50 | Tower Mode 


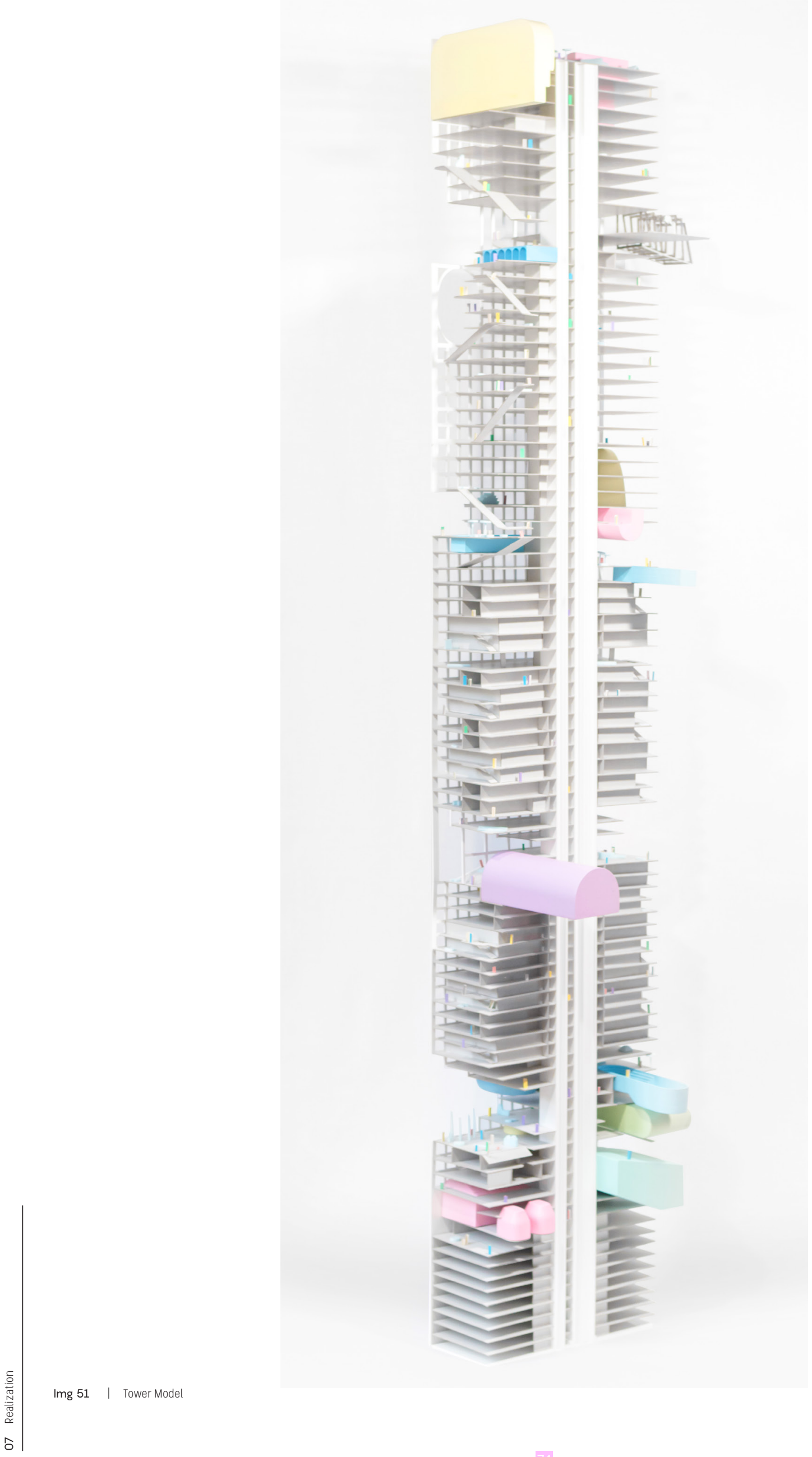




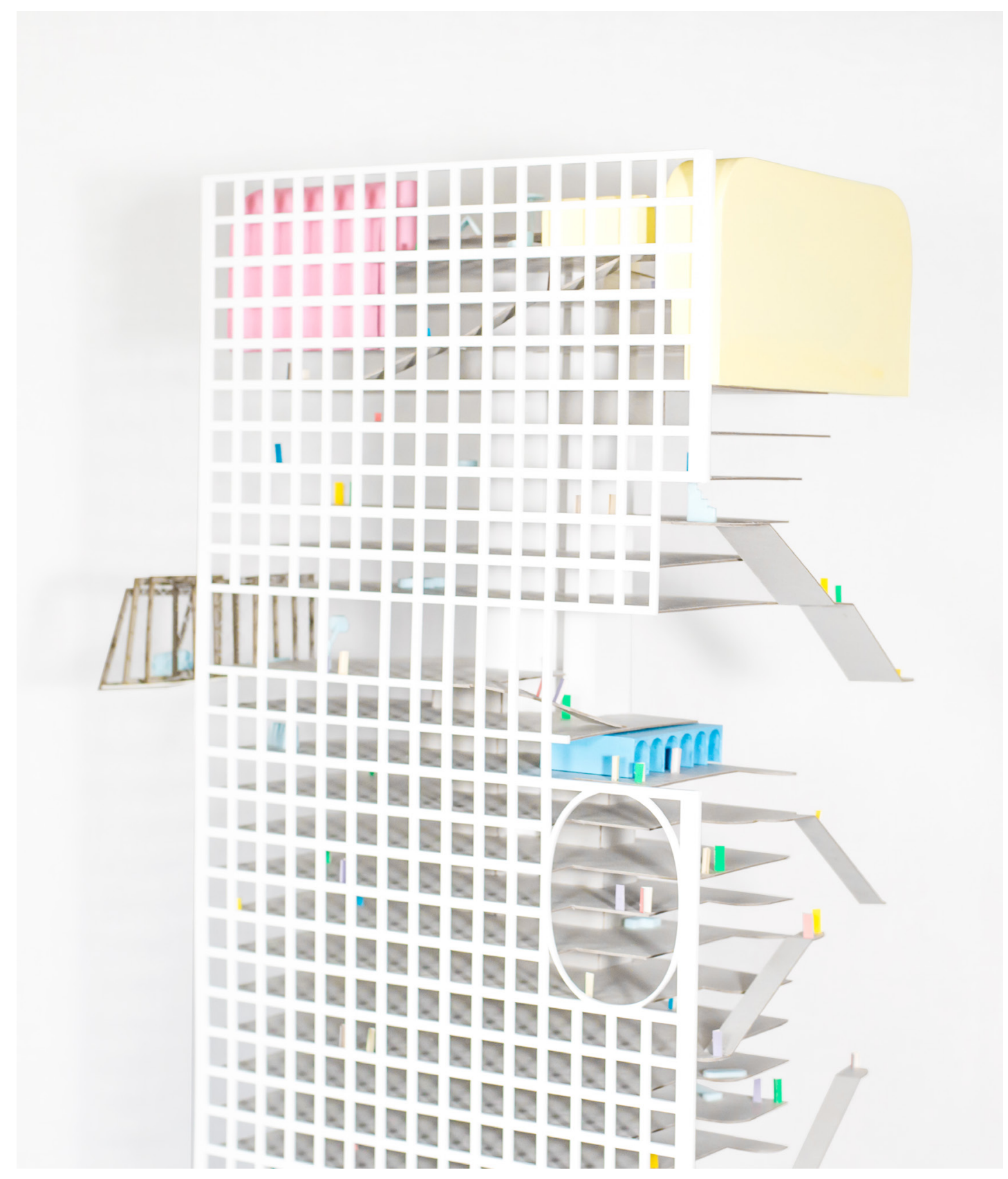




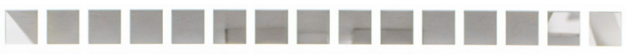

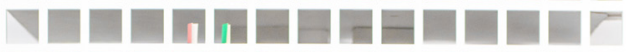

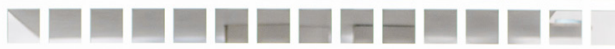

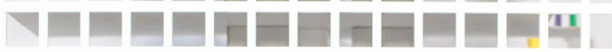

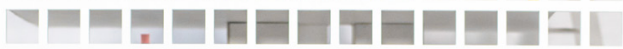

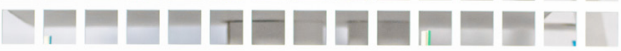

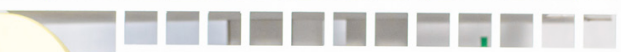

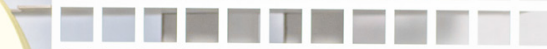

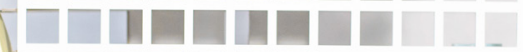

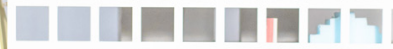

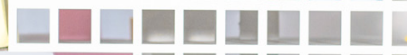

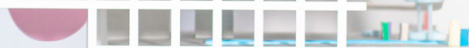

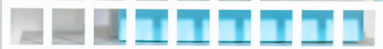

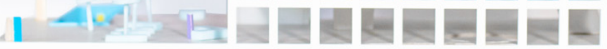

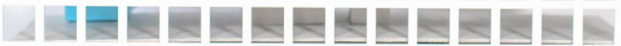

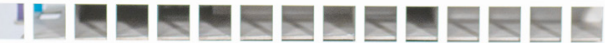

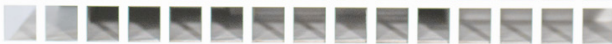

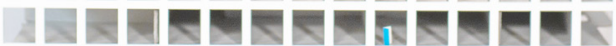

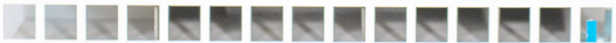

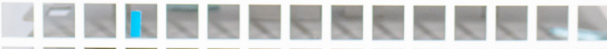
Img 53 | Tower Mode

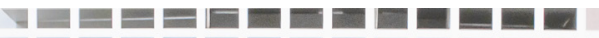

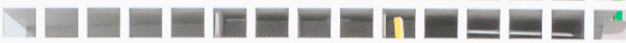

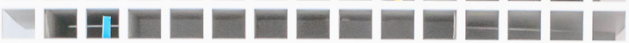

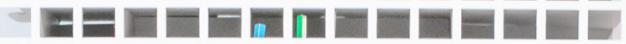

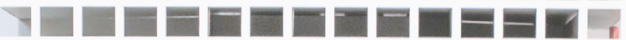

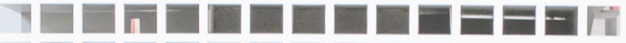

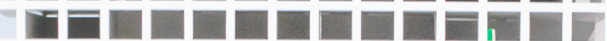

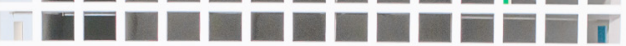

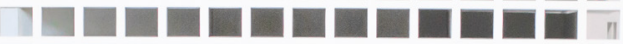
1ㅁㅁㅁㅁㅁㅁㅁ

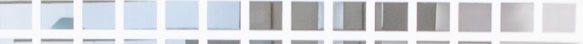

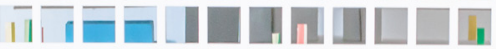

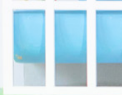

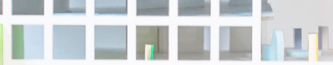

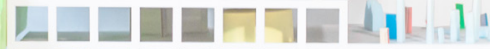

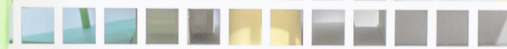

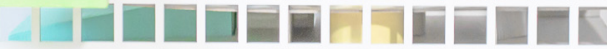

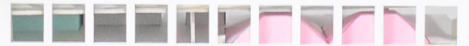

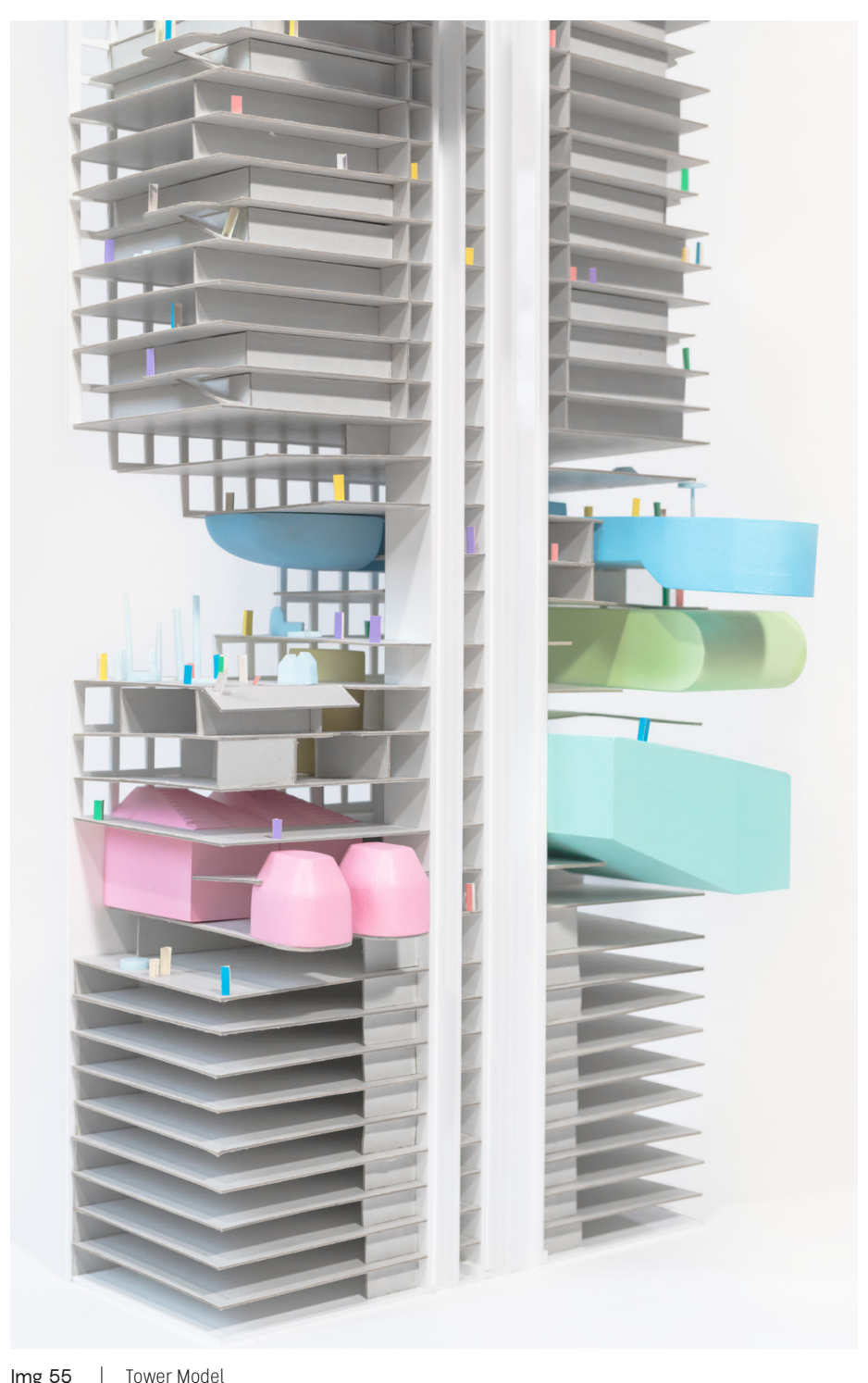




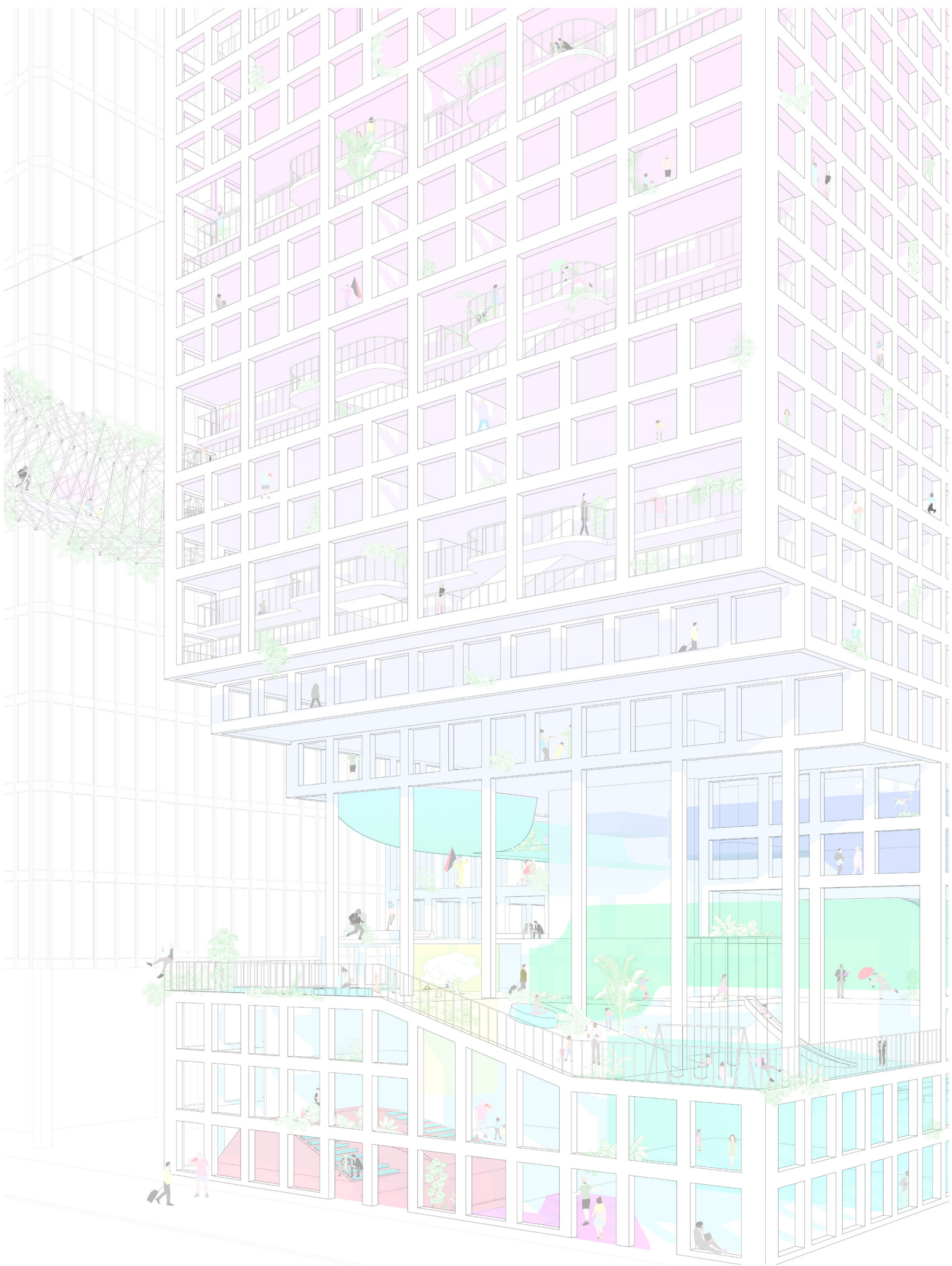




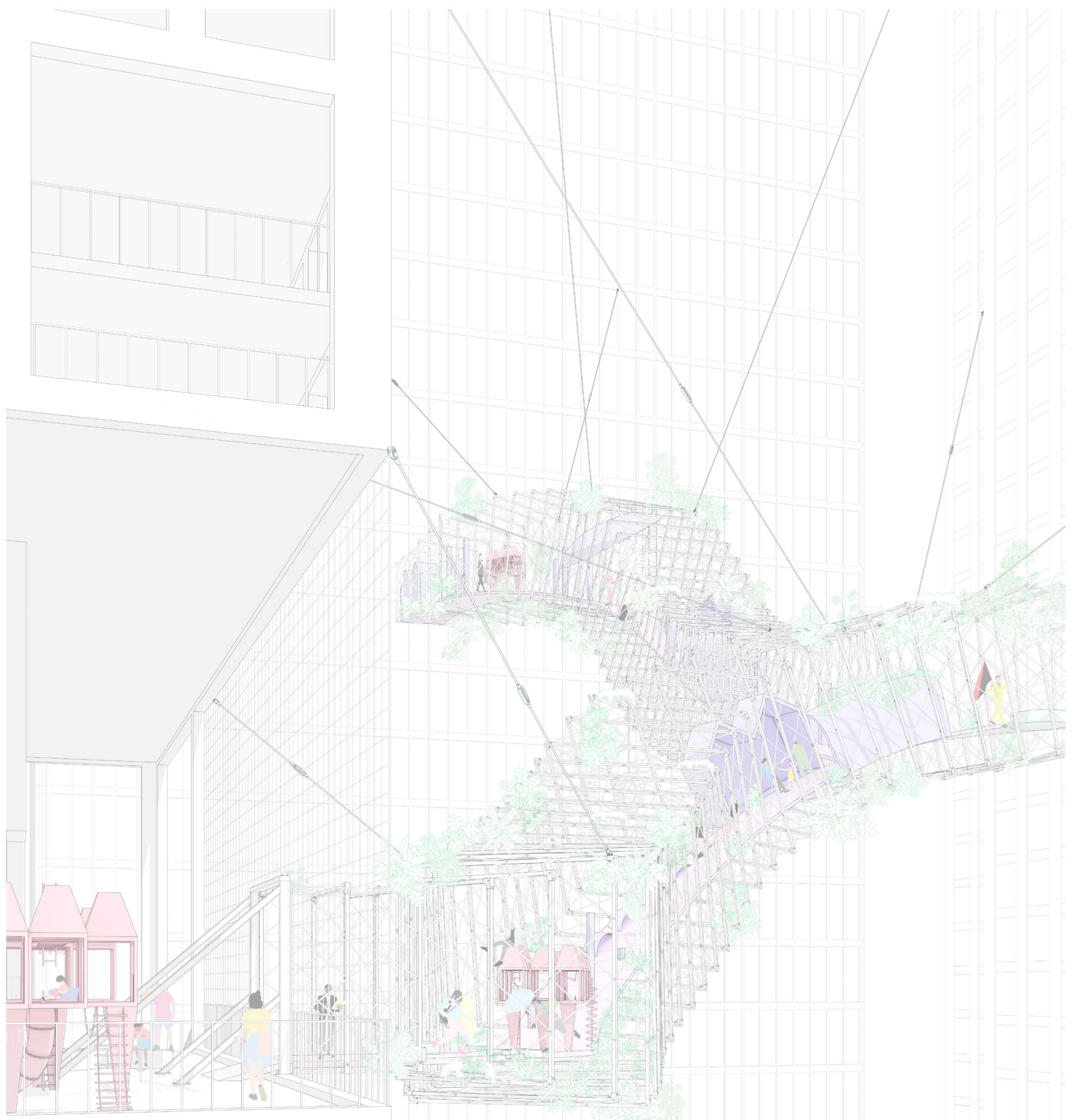

Img 57 | Armature Connection Green space attaches to the new and existing towers. 


\section{CONCLUSION}

Uncertainty is a driving force for this project, it exists as a foil to the encompassing Bigness of the skyscrapers. This uncertainty will not replace or abolish the neoliberal structures that control the site, it enables the adoption and transformation of the spaces to be inclusive to both the dominant and alternate publics that inhabit Toronto's financial district. An urban network is created that comprises the repurposing of existing floors in skyscrapers, creating horizontal circulation above the ground plane through suspended greenspaces and building community oriented mixeduse towers. These design strategies provide the frame for the Staging of Uncertainty that the publics inhabits. Life in the city's core acquires its qualities of heterogeneity through the overlaps of diverse publics.

The repurposing of Bigness and the neoliberal spaces of the district creates a system that is capable of adapting to the shifting unidentifiable publics. Creating spaces that cater to vast arrays of publics is crucial to the design of cities that are meant to be inhabited and not simply observed from the outside. Looking towards the future, Toronto's urban core is in constant flux. The research-by-design methodology created a learning process that evolved my understanding of social and power dynamics of the site to properly propose an alternate vision of habitation in the city core. The speculative nature of the design evolved as it shifted from solely spatial

tactics to a proper understanding of the publics that experience the 
site and their needs. Varying publics, communities and designed spaces continually reinvent themselves and the spaces they inhabit, wandering through the urban center becomes an exercise in experiencing community and culture. The public sphere is readdressed to incorporate life, not the strict adherence to the capital structures that do not design spaces for inhabitation. 


\section{BIBLIOGRAPHY}

“Board Members.” Board Members - Ontario Teachers’ Pension Plan. Web. 12 Nov 2019 https://www.otpp.com/corporate/board-members.

"Board of Directors.” OMERS. Web. 13 Nov 2019

https://www.omers.com/About-OMERS/OMERS_Governance/Administration_ Corporation/Board-of-Directors.

British Columbia Investment Management Corporation. Corporate Annual Report. 2018. Web. 13 Nov 2019 https://www.bci.ca/publications/

Brookfield Property Partners L.P. 2018 Annual Report. 2018. Web. 10 November 2019 https://bpy.brookfield.com/reports-and-filings/financial-reports/annual-reports

Brookfield Property Partners L.P. Board of Directors. 2018. Web. 10 November 2019 https://bpy.brookfield.com/corporate-governance/board-of-directors

Fraser, Nancy. "Rethinking the Public Sphere: A Contribution to the Critique of Actually Existing Democracy." Social Text, no. 25/26, 1990,

Goldstein, Natalie. Globalization and Free Trade. Facts On File, 2012.

“Greater Toronto Area Office Marketview, Q3 2019.” CBRE. Web. Nov 192019 https://www.cbre.ca/en/research-and-reports/local-market-reports/toronto-realestate-market-reports 
James, Paul. Globalization and Culture, Volume III, Global-Local Consumption. SAGE, 2010.

Koolhaas, Rem, and Bruce Mau. S, M, L, XL. Monacelli Press, 1995.

Koolhaas, Rem. Delirious New York. Monacelli Press, 1978.

Ontario Municipal Employees Retirement System. 2018 Annual Report. 2018. Web. 13 Nov 2019 https://www.omers.com/About-OMERS/Annual-Reporting

Ontario Teachers' Pension Plan. 2018 Annual Report. 2018. Web. 10 Nov 2019 https://www. otpp.com/corporate/ontario-teachers-reporting

Scott, Felicity. Architecture or Techno-Utopia: Politics after Modernism. MIT Press, 2007.

Sun Life Financial Inc. 2018 Annual Report. 2018. Web. 12 November 2019

https://www.sunlife.com/Global/Investors/Presentations+and+events/

Annual+meetings?vgnLocale=en_CA

Sun Life Financial Inc. Management Information Circular. 2019. Web. 12 November 2019 https://www.sunlife.com/Global/Investors/Presentations+and+events/ Annual+meetings?vgnLocale=en_CA

Warner, Michael. Publics and Counterpublics. Zone Books, 2002.

Yoos, Jennifer, et al. Parallel Cities: The Multilevel Metropolis. Walker Art Center, 2016. 